\title{
LAS ARMAS EN LA HISTORIA DE LA RECONQUISTA
}

\author{
POR \\ ADA BRUHN DE HOFFMEYER
}

\section{INTRODUCCIÓN}

LAS armas en la historia es un tema muy importante mirándolo desde diversos aspectos. Las armas escriben la historia política, así como la de las grandes invasiones, ataques, defensas, batallas y campañas, además de los sitios, con su poliorcética especial y sus máquinas de guerra: la artillería de aquellas épocas. Las armas relatan asimismo la historia de las civilizaciones en todos sus aspectos: metalurgia, técnica, industria, comercio, rutas comerciales, la economía de los Estados avanzados y también la de las tribus primitivas; la de las sociedades y sus clases sociales, sus necesidades y sus formas de vida más lujosas. Con sus armas, los reyes y la nobleza, sus escuderos y sus cortesanos, tienen diversión en torneos, justas reales, esgrima y caza. Posiblemente no haya ninguna forma de vida ni de cultura donde no aparezcan las armas, con su historia, su desarrollo y sus progresos. Incluso en la vida religiosa - sea cristiana, musulmana, pagana o primitiva-, con sus ritos y ceremonias especiales, su simbolismo, culto y desarrollo, las armas adquieren gran importancia.

Estas tienen papel preponderante desde las primeras épocas de nuestra civilización, que llega hasta el presente. En todas las partes del mundo se buscan como importantes objetos arqueológicos. Las armas -como destructoras de civilizaciones y como constructoras de civilizacionesse difunden por todas las regiones. La investigación de las armas antiguas - - sean de la Prehistoria o de la Antigüedad, de los griegos o romanos, sean de las épocas medievales o posteriores - tiene excepcional papel como ciencia auxiliar en búsquedas arqueológicas, antropológicas, etnográficas, políticas, así como en bellas artes y arquitectura (castillos y fortalezas), como portadora de civilizaciones.

No obstante lo dicho, las armas también tienen su propia historia, su propia arqueología, exactamente igual que lo tienen otras clases de objetos arqueológicos, por ejemplo, cerámica, fíbulas, utensilios de la- 
branza, etc. Su desarrollo se ha efectuado casi siempre con cierta velocidad y con un rítmo propio, según las necesidades de la sociedad humana. Ha habido algunas épocas en las que han estado estancadas, con retrasos y conservadurismo. En momentos de guerri y desorden, el desarrollo ha sido muy rápido. Las invenciones, enionces, han sido prolíficas. La eterna competencia entre las armas ofensivas y las defensivas ha existido desde los primeros tiempos de nuestra civilización.

En épocas difíciles, con muchos problemas y turbaciones, predominan en las representaciones pictográficas ciertos motivos, temas y formas de guerrear con sus respectivas armas. Esto es particularmente significativo en el Medievo, bien el alto o el bajo. Los dos momentos se distinguen por sus propios motivos especiales, marcados en la vida política, social y rcligiosa de los países respectivos. Los siglos $\mathrm{x}$, xI e incluso hasta el xil están influidos por los terrores casi apocalípticos. Reflejan escenas apocalípticas de la Biblia; lo mismo podemos apreciar en los manuscritos iluminados del Comentario al Apocalipsis del Beato de Liébana, con sus grandes y efectivas armas, con luchas de dos contra dos, así como guerreros luchando contra bestias y monstruos. Las batallas en campo abierto no son tan frecuentes, ni tampoco los sitios de ciudacles o castillos, aunque desde luego existen, como, por ejemplo, las que nos muestran el sitio de Jerusalén, Nabucodonosor II decapitando cautivos despućs de sus ataques y algunas otras representaciones de estos siglos. Generalmente, los ejércitos de estos manuscritos son los ejércitos del Señor, los ejércitos celestes. Existen Biblias mozárabes con escenas del Antiguo Testamento; la Biblia primera de San Isidoro de León, con representaciones de Goliat y el ejérciio de los filisteos, de ca.960, y la Biblia de Ucclés, de la primera parte del siglo XI. A principios del xiı aún pueden verse motivos del $\Lambda$ pocalipsis, pero los temas van cambiando y nos presentan los provenientes e inspirados en los grandes movimientos de Europa occidental, las Cruzadas, particularmente de Francia, Inglaterra, Italia y Aicmania hacia Tierra Santa, con sus batallas contra los sarracenos y los turcos; también las amistosas y hostiles relaciones con los bizantinos. Se aprecian claramente otras formas de combatil y otro tipo de armamento, más apto para la guerra, con menos simbolismo y más eficaz.

Las Cruzadas de finales de los siglos XI, XII y especialmente del XIII influyeron en la creación de nuevas armas. Las Cruzadas al Oriente -con participación de los caballeros de Francia, Inglaterra, Flandes y, en cicrto grado, tambiér de Alemania (Federico Barbarroja) - daban una estampa de unidad, casi una clase de internacionalidad a Europa occiclental. Esta influencia afecta asimismo a la Península Ibérica, aunque en menor grado que en Francia, Italia o Inglaterra. El país europeo más 
culto y que más aportaba era sin duda Francia. El siglo xir I es, sobre todo, el apogeo y el fin de las Cruzadas, las Cruzadas de San Luis de Francia.

De este siglo encontramos muchísimas representaciones de la guerra y muchos tipos de armas, más desarrollados que antes. Los temas dominantes son los caracterizados por las guerras en Tierra Santa, con escenas de la Biblia, especialmente del Antiguo Testamento. Además, esta época es la representativa de los trovadores y los Minnesänger, con su armamento «caballeresco», la vida de las cortes reales y principescas, sus torneos, sus damas y sus aventuras amorosas. Es la verdadera época de la caballería, donde fácilmente se aprecian todos los tipos de armas en toda su función y uso, para el bien y el mal. El desarrollo continúa lentamente en la primera cuarta parte del siglo XIV, aunque con pocas excepciones (importancia de la infantería en 1302 y 1304, más algunas otras batallas). Antes de mediados del siglo, sin embargo, nos encontramos con un importante cambio, no sólo en el armamento, sino más aún en el arte de la guerra. Este nuevo desarrollo en el arte de la guerra trae consigo otros tipos de armas, otras maneras de usarlas y otras funciones. Es, entre otras cosas, una de las consecuencias que proporcionó el comienzo de la Guerra de los Cien Años entre Francia e Inglaterra. Del mismo modo, el cambio social nos trae cambios en el arte y organización militar, y con éste vienen otros tipos de guerreros con diferentes necesidades de armas. También en el arte cambian los temas. Hay menos representaciones de sitios y de batallas. Los motivos del Antiguo Testamento disminuyen; sin embargo, hay más escenas en el Nuevo que antes y, probablemente, más en España que en otros países. En escultura y en pintura, las escenas de la Pasión predominan, entre ellas, sobre todo, las representadas en el Santo Sepulcro, con los soldados romanos desmayados y plenamente armados. En la escena de la Resurrección es muy frecuente ver a los soldados romanos desmayados con sus armas caídas en el suelo al lado de la tumba. La Resurrección misma es un tema predilecto de la pintura, pero en la escultura se repiten las escenas de los soldados desmayados, especialmente en los relieves laterales de la tumba del difunto. Estos monumentos nos dan una auténtica muestra del armamento de la época, con sus armaduras, cascos, lanzas, espadas, dagas, hachas, alabardas y sus escudos. Además, las muchas estatuas yacentes, vestido con cota de mallas, armas y frecuentemente su escudo, no sólo en Cataluña, sino también en Castilla, Galicia, Navarra, Valencia y muchas otras partes de la Península, son de gran importancia, con sus realistas representaciones. Estos monumentos dan una impresión del auténtico armamento del caballero en el siglo XIV. Ya en el XV cambian los tipos y los temas, así como muchos detalles del armamento. Son di- 


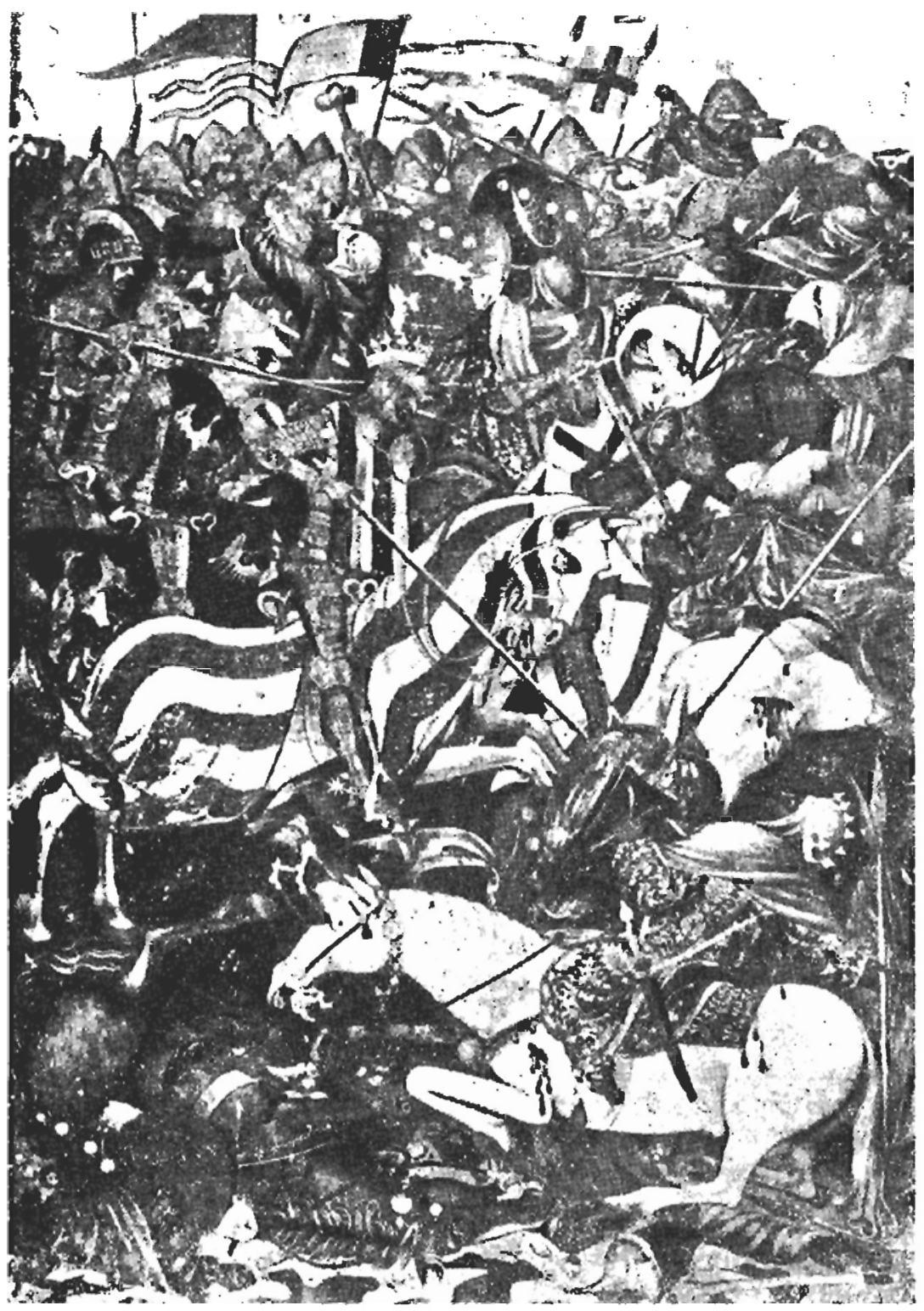

Fig. 1.-Reiable de San Jorge, parle central, por Marcal de Sax, Valencia, ca. 13931410. Vicloria and Alberl Mus. Londres. Representa al rey Pedres I de Aragón (1094.1104) evaciendo al rey moro de Zaragoza en la halalla de Alcoraz con la ajude de Sen Jorge. 
ferentes al los del siglo pasado, con distintas formas, más variadas, etc.; aquí termina una época: la Edad Media, y empieza una nueva: el Renacimicnto. La guerra en el siglo $\mathrm{xv}$ cambia lentamente y presenta otros tipos de guerreros, otros tipos de armas, aunque todavía domina la caballería real y la noble. La época de la caballería auténtica, con sus armas y sus ideales, está acabando; ahora el dominio pertenece a los guerreros de a pie: los alabarderos, piqueneros y lansquenetes, con mandobles, katzbalger y armas de fuego. En las campañas y en los sitios ya funcionan este tipo de armas: artillería con bombardas, lombardas, falconetes, etc., así como otros de armas con pólvora, yue cambian fundamentalmente el arte de la guerra y la arquitectura militar.

El fin de la época medieval y el comienzo del Renacimiento tiene su más fuerte expresión en monumentos, como la parte central del gran retablo, hoy en el Victoria and Albert Museum en Londres, de Marçal de Sax (Fig. 1), de Valencia (¿de origen alemán?), del comienzo del siglo xv, y los relieves tallados, de hacia 1495-1520, con la Reconquista de Granada, Alhama, etc., en las catedrales de Toledo y Granada. En el primer monumento no es posible distinguir las armas de fuego, ya que todavía son los ejércitos medievales, The Age of Chivalry; pero en los

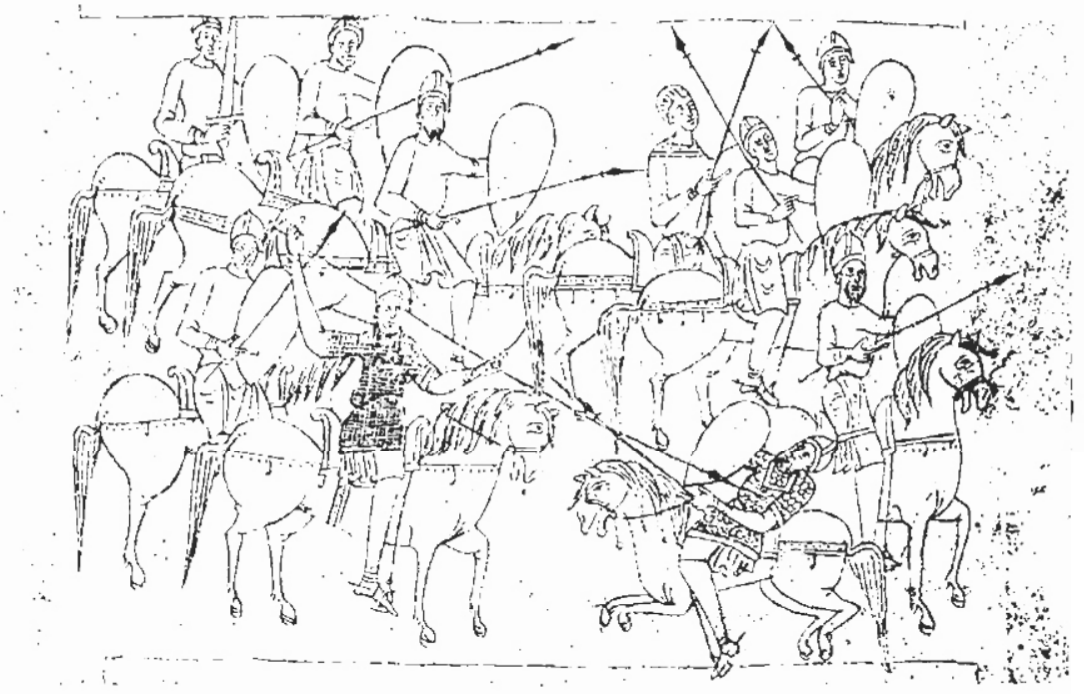

Fig. 2,-Biblia de Roda, fol. 145r, del Monasterio de San Pedro de Roda, ca. 1047. Bibl. Nat. Paris. 
dos últimos se aprecian las armas de fuego portátiles y la artillería con bombardas. Aquí, claramente, se ven ya los Jundamentos de los ejércitos modernos.

\section{LAS FUENTES PENINSULARES DE LA ÉPOCA MEDIEVAL ALTA Y LA TRANSICIÓN A LA ÉPOCA BAJA}

Casi toda la época medieval se distingue por su carencia de material arqueológico. En contraste con este fenómeno, las fuentes en arte y en litcratura son informativas, pudiendo verlas en las ilustraciones de los manuscritos y otros objetos de arte. Gracias a estas fuentes nos es posible seguir el desarrollo que tuvo el armamento, tanto ofensivo como defensivo, incluso a veces poliorcético, no sólo entre los musulmanes en el sur, sino especialmente entre los cristianos en el norte. Dos documentos de la mayor importancia para la historia de las armas y las armaduras desde los siglos XI y XII son las inestimables Biblias catalanas: Biblia de Roda y Biblia de Ripoll (Figs. 2 y 3). Ambas pertenecen a la primera

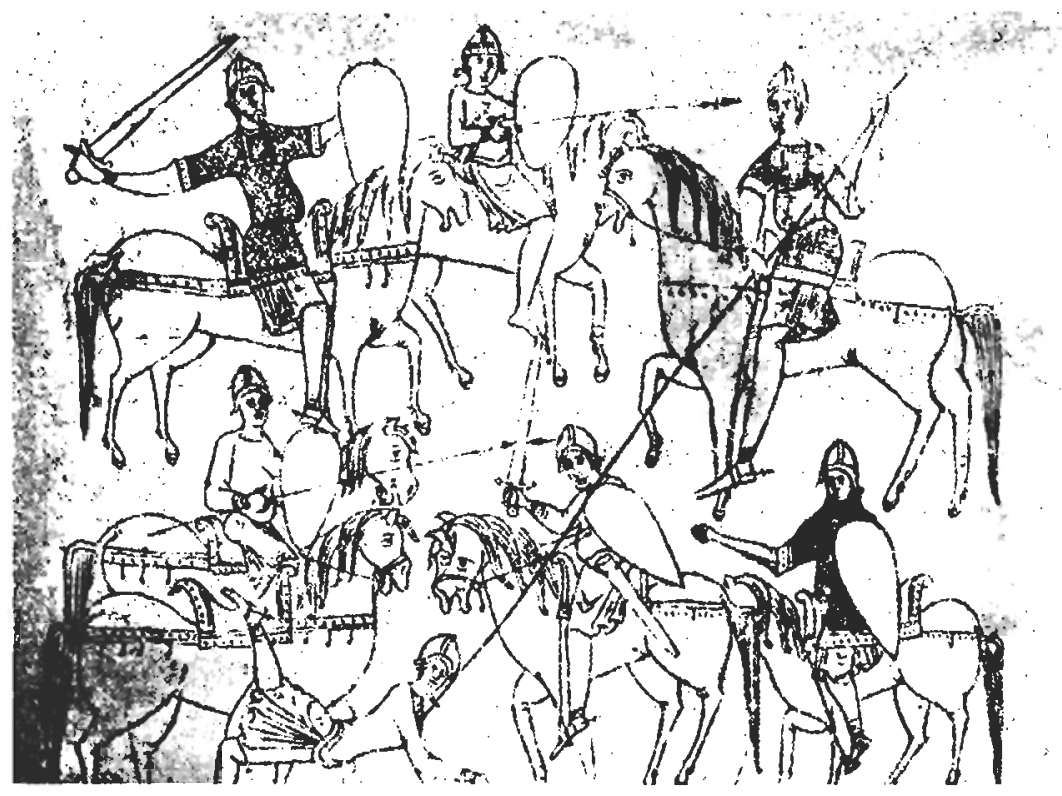

FIG. 3.-Biblia de Roda, fol. 145v. Del Monusterio de San Pedro de Roda. 


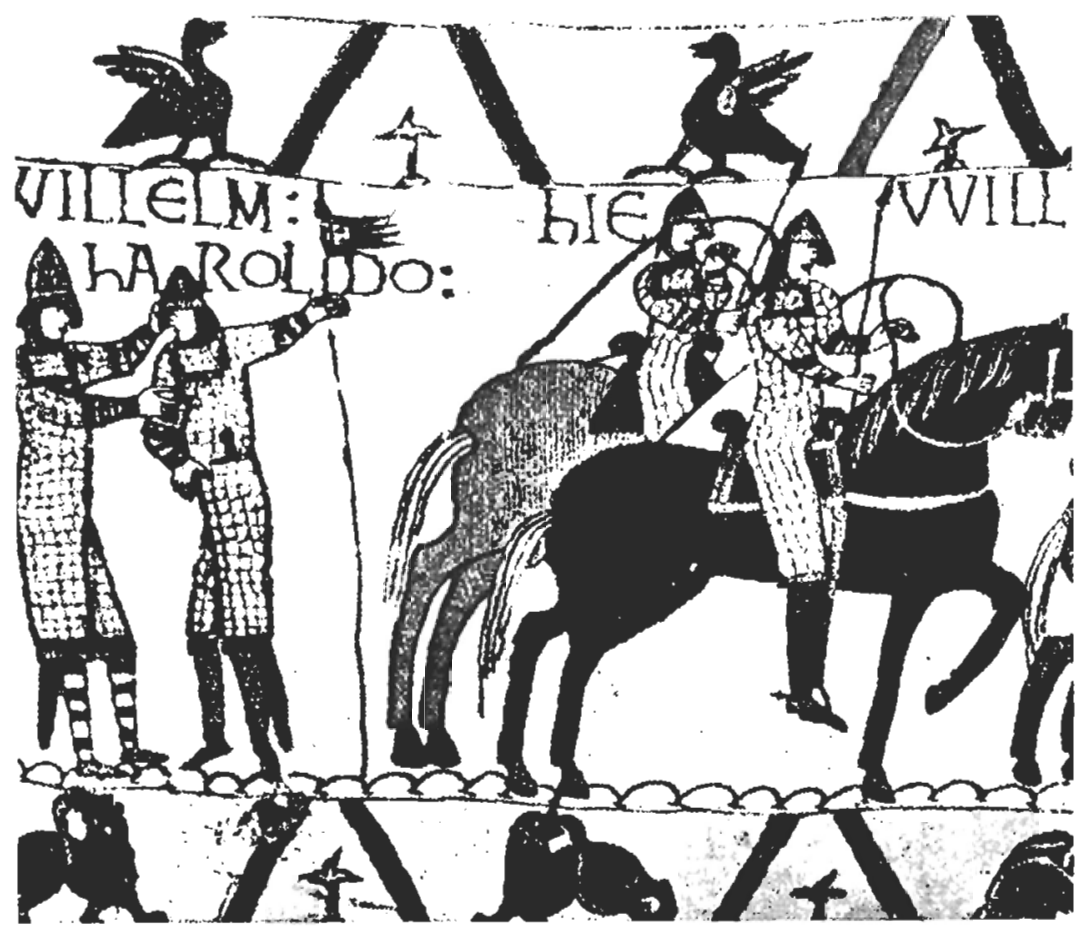

Fig. 4.-Caballería del Tapiz de Bayeux, ca. 1077.

mitad del siglo xi, una probablemente terminada hacia 1047. La Biblia de Roda procede del Monasterio de San Pedro de Roda, hoy en ruinas, que el mariscal Noailles llevó a Francia al final del siglo xvir; hoy se encuentra en la Bibliothèque Nationale en París (Ms. lat. 6). El origen de la Biblia de Ripoll es el Monasterio de Santa María de Ripoll, y se conserva en la Biblioteca Apostólica Vaticana (Vat. Lat. 5729). De la iglesia de este monasterio existen también los relieves de la portada, aproximadanente de 1160, que representan escenas del Antiguo 'Tcstamento: el Exodo y luchas entre israelitas y sus enemigos, con armamento militar de infantería, así como la caballería. Estos relieves y las dos Biblias tienen enorme y excepcional importancia para la muestra del armamento militar de fin de la época transitoria entre la medieval alta y la baja, con sus raíces profundamente ancladas en tradiciones posroma- 
nas, carolingias y bizantinas, relacionadas con ciertas iluminaciones de los siglos IX-XI: los salterios de Utrecht (Reims, ca. 830), Josua Roll (siglo x, Vaticano), Psallerio Aureo en el monasterio de Saint-Gall en Suiza (ca. 850) y varios otros manuscritos de la misma época.

Son de la misma importancia en la historia del armamento medieval en la Península que el famoso Tapiz de Bayeux para el de la Europa occidental (Fig. 4). Todos indican vinculación entre la antigua cultura tardía y la bizantina con la civilización medieval occidental en la Península. Con las Biblias catalanas termina una época; el tapiz de Bayeux abre una época nueva en armamento y en arle militar, no obstante pertenecen estos documentos al mismo siglo; el tapiz de Bayeux es unos cuarenta años posterior a las Biblias, de 1077 aproximadamente. Su influencia se nota en e! siglo xul. Ahora se ve un cambio, una transición en el arte de la guerra, que se debe a una nueva táctica, con otras formas para combatir. Son las consecuencias de la victoria de la caballería con

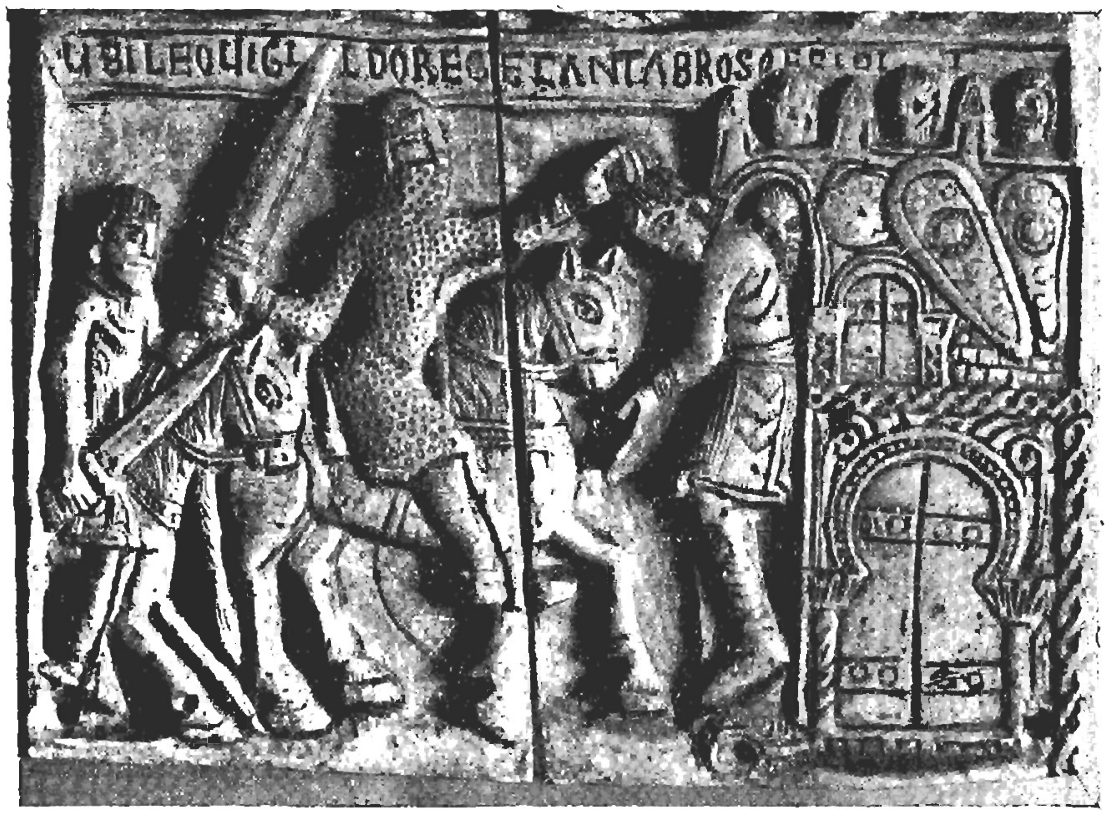

Fig. 5.-El rey visigodo Lenvigildo decapttando al caudillo rebelde de los cántabros. Relieve de martil del relicario de San Millán de la Cogolla, siglo XI. Mus. Nac. Arqueológico. Madrid. Compárese con el relicve de San Vicenee, Avila (Fig. 6). 


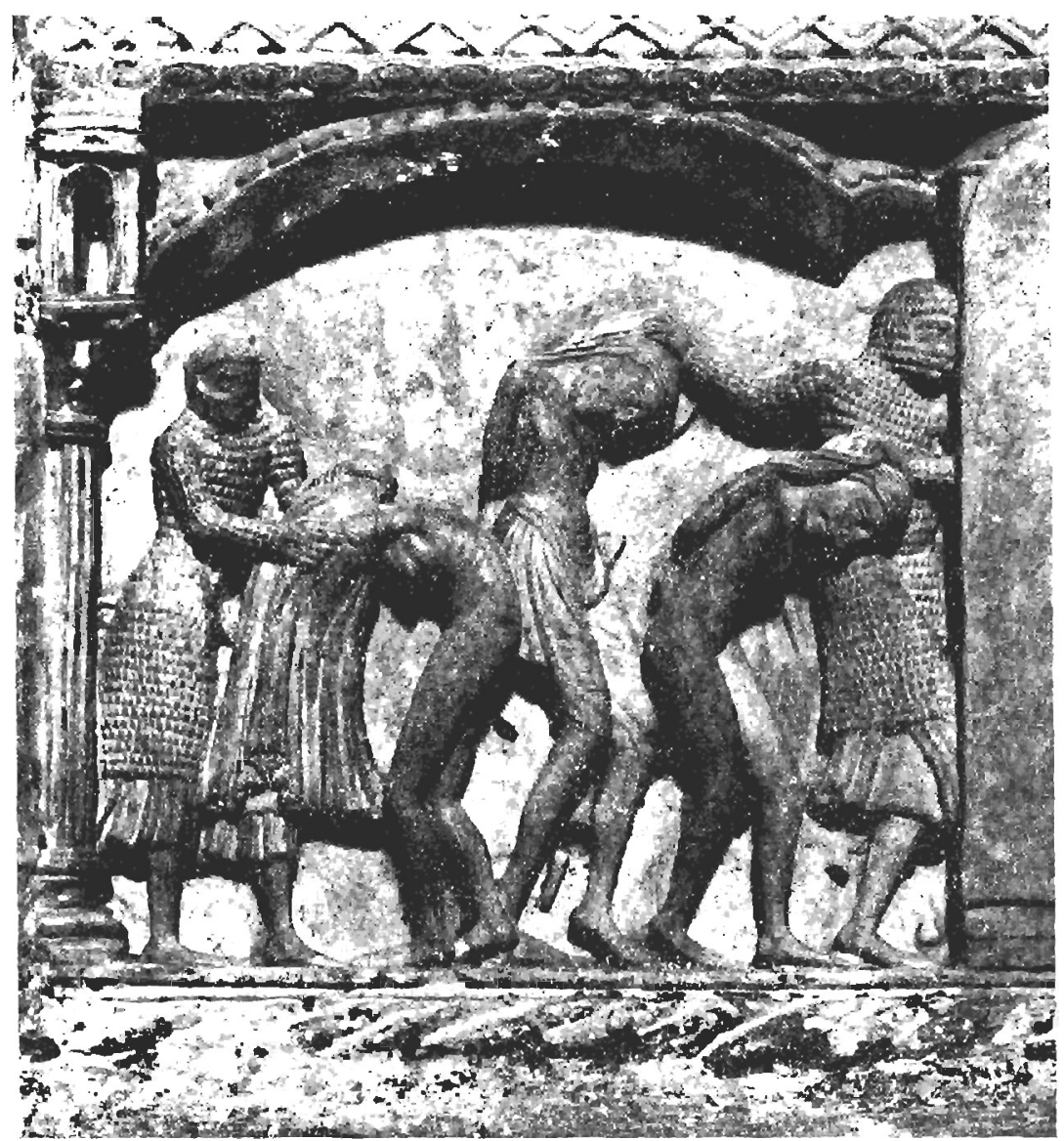

Fic. 6.- Marlirio de San Vicenle y sus dos hermanas. Relieve del monumento sepul cral de la Basilica de San Vicente, Avila, ca. 1190.

lanza y espada en la batalls de Hastings, en 1066, en Inglatera, y en el año 1081 el fracaso de los Varangians de a pie en Durazzo frente a la caballería nomanda. Los ejércitos entran en la verdadera época feudal, generalmente con sus pequeños grupos de caballería, con una serie de choques atroces y brutos, armamento pesado y con escasa o estancada táctica y estrategia. Como ejemplo, en España, como representación del 
nuevo armamento, es de resaltar el relieve de marfil de la pequeña arca de San Millán de la Cogolla, hoy en el Museo Arqueológico Nacional, en Madrid, de hacia 1060-1080 (Fig. 5), representando al rey Leovigildo decapitando al rey cántabro y sus rebeldes. Es un precursor del armamento de los relieves del monumento de San Vicente, en su basílica en Avila, de hacia 1190 (Fig. 6).

\section{LA HISTORIA DE LA RECONQUista DEL SIGLO XIII}

A pesar de que la lanza significaba, sin duda ninguna, el arma más importante y fuerte en las guerras de los siglos XII y XIII, la bisloria de la Reconquista en España la escribió la espada: el arma noble, caballeresca y cristiana. Espadas del siglo XII apenas se han conservado en España, pero del XıII se han preservado algunas, preciosas e históricas. La espada era el arma más estimada y venerada, de la que el arte nos muestra varios tipos. Generalmente son fuertes, con buenas hojas cortantes, rectas con dos filos, con una canal en el centro casi hasta la punta, que, con preferencia, suele ser redondeada. La canal, frecuentemente, en este siglo XII y en el XIII, tiene una inscripción, hecha con fino hilo de plata, latón o cobre, y a menudo dorada. Las antiguas inscripciones, de los siglos $\mathrm{Ix}, \mathrm{x}$ y $\mathrm{XI}$, con un hilo grueso de hierro, solamente se nota de cuando en cuando; las de hilo fino van acompañadas de ornamentos en forma de flores, pájaros, follaje, etc., en estilo románico e intercalado por letras decorativas, con inscripciones enteras o abreviadas, casi incomprensibles para nosotros; su contenido es típico en la época de las grandes Cruzadas (Fig. 7). Todavía existen en este siglo inscripciones como: Homo Dei, in nomine Domini, del siglo xI y parte del xII; ahora podemos notar: Deus, benedictus Deus meus, invocaciones a la Virgen o a San Pedro. Otras dicen Jesus rex salvador. Hay también fragmentos de los salmos: Eripe nos («Eripe me de manu inimicorum meorum», Sal 30,16), Redemisti, etc. Algunas veces son tan abreviadas que parece imposible interpretarlas. También existen escenas completamente simbólicas. Las empuñaduras son generalmente cortas y fuertes, el pomo en forma de una nuez del Brasil, castaña, o circular, en forma de disco, plano o grueso, y hasta hueco, y de vez en vez con restos de alguna reliquia. Generalmente, el material es hierro, con frecuencia plateado, o bronce (dorado); puede ser decorado con ornamentos o símbolos, grabados o esmaltados, hasta en forma de figuras heráldicas (Pierre de Lusignan, Pierre de Dreux, encontradas en Tierra Santa). Las espadas guerreras son grandes, fuertes y sencillas; las hay más pequeñas, para ceñir cuando el caballero está montado y elegantemente vestido (Juan 
de Tarifa, catedral de Toledo). Para ceremonias existen espadas preciosas, como las de San Fernando en Sevilla y San Fernando o Alfonso el Sabio en la Real Armería en Madrid, conocidas en las representaciones artísticas. La forma de la cruz es significativa para la época, no sólo en la realidad y en el arte, también en la literatura. Alfonso el Sabio, en Las Siete
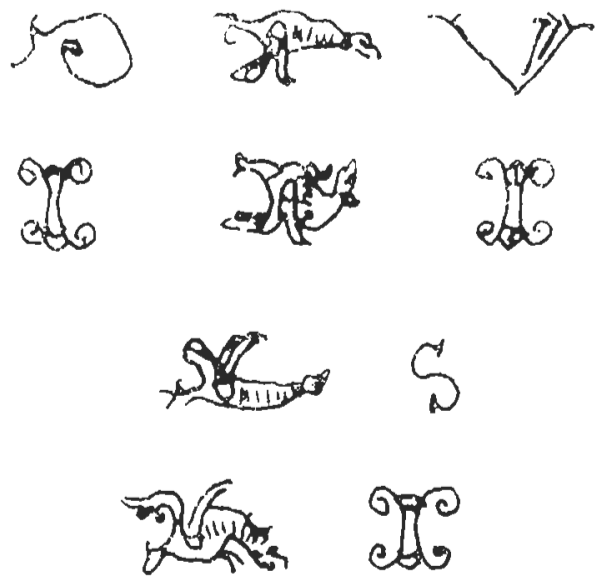

Fig. 7.-Espada medieval, ca. 1050-1150, llamada «La Tizona» del Cid, según el «Invenlario del tesoro de los Reyes Católicos en Segovias, por Gaspar de Bricio en 1503. Real A.mería, Madrid (G 180).

Partidas, habla (II, XXI, IV) de la espada, su importancia y significación. El nieto de San Fernando, don Juan Manuel, dice en su libro de los Estados: «La espada significa tres cosas: la primera, fortaleza, porque es de fierro; la segunda, justicia, porque corta de ambos las partes; la tercera, la cruz». A pesar de que la lanza, sin duda alguna, era lo más efectivo en armamento (al comenzar la lucha), para la guerra de aquella época la espada era considerada la más distinguida, noble y la más impor- 
tante. El Spcculum Regale, de Noruega (ca. 1220-1230), influido por la literatura francesa, dice precisamente que, en guerra, una lanza sirve mejor que dos espadas. Pero la espada — aparte de su significación como símbolo cristiano-, también desde épocas remotas, lo ha sido del hombre libre, y en ciertos países paganos, además, tuvo su propio culto.

La espada en los países cristianos de aquella época fue considerada el simbolo de Dios. El Apocalipsis, en 19,15.21 (pero también en otros lugares), dice: «De su boca sale una espada aguda para herir con ella a las naciones... Los demás fueron muertos por la espada que salía de la boca al que montaba el caballo». Así puede verse también en otras ilustraciones del siglo, desde el ms. mozárabe de la catedral de Burgo de Osma, de 1086 (fol. 85v), pasando por las de España, Francia y otros países. Significaba el poder viviente de Dios, que los reyes habian recibido deĺ mismo Dios. Por estas razones, las espadas para ceremonia fueron ricamente adornadas con oro, esmaltes, piedras preciosas, ataujía en oro y plata, y hasta con símbolos y reliquias, así como para Ordenes militares, por ejemplo, las de Calatrava, Santiago, Templarios, etc. Con ella recibió el joven caballero su «espaldarazo» o su vasallaje, maestrazgo, etc.

Las lanzas, probablemente, son las armas más difíciles de determinar y clasificar cronológicamente y por naciones. En estas armas, el material con el que eran fabricadas hay que buscarlo en las ilustraciones y otras formas artísticas. Existe escasa variación en los siglos xi, xil y xili, pero ya en este último comienza un cambio en los tipos y tamaños, consecuencia del desarrollo en el arte de la guerra. Conocemos varios íipos y tamaños de ellas: hierros largos, como dagas fuertes, con nervio en el centro; cortas y fuertes en forma de hoja de oliva y romboidal, con tubos largas y cortos. Todavía se ven de vez en cliando aletas entre hoja y tubo, aunque son más raros. Con el cambio en arte de la guerra las aletas no son cómodas ni para el caballero ni para el caballo, pues resultan molestas para ambos.

Las armas defensivas de esta época consisten en la loriga, de malla de hierro, larga, con mangas hasta la muñeca, frecuentemente con su almófar, hecho de una pieza con la cota de malla. Con malla se protegen también las piernas y pies, existiendo varios tipos de malla o de escama para estos trajes. Entre las mejores y más típicas representaciones de loriga con almófar se encuentran las representadas en el monumento sepulcral de San Vicente, en Avila, de 1.190, ejemplo de arma defensiva de la Reconquista de Alfonso VIII, al final del siglo xu y comienzos del xiII (Fig. 6). Otros ejemplos característicos podemos verlos en los capiteles del palacio de los reyes de Navarra en Estella (ca. 1200). En este último monumento se aprecian unos buenos ejemplos del escudo 

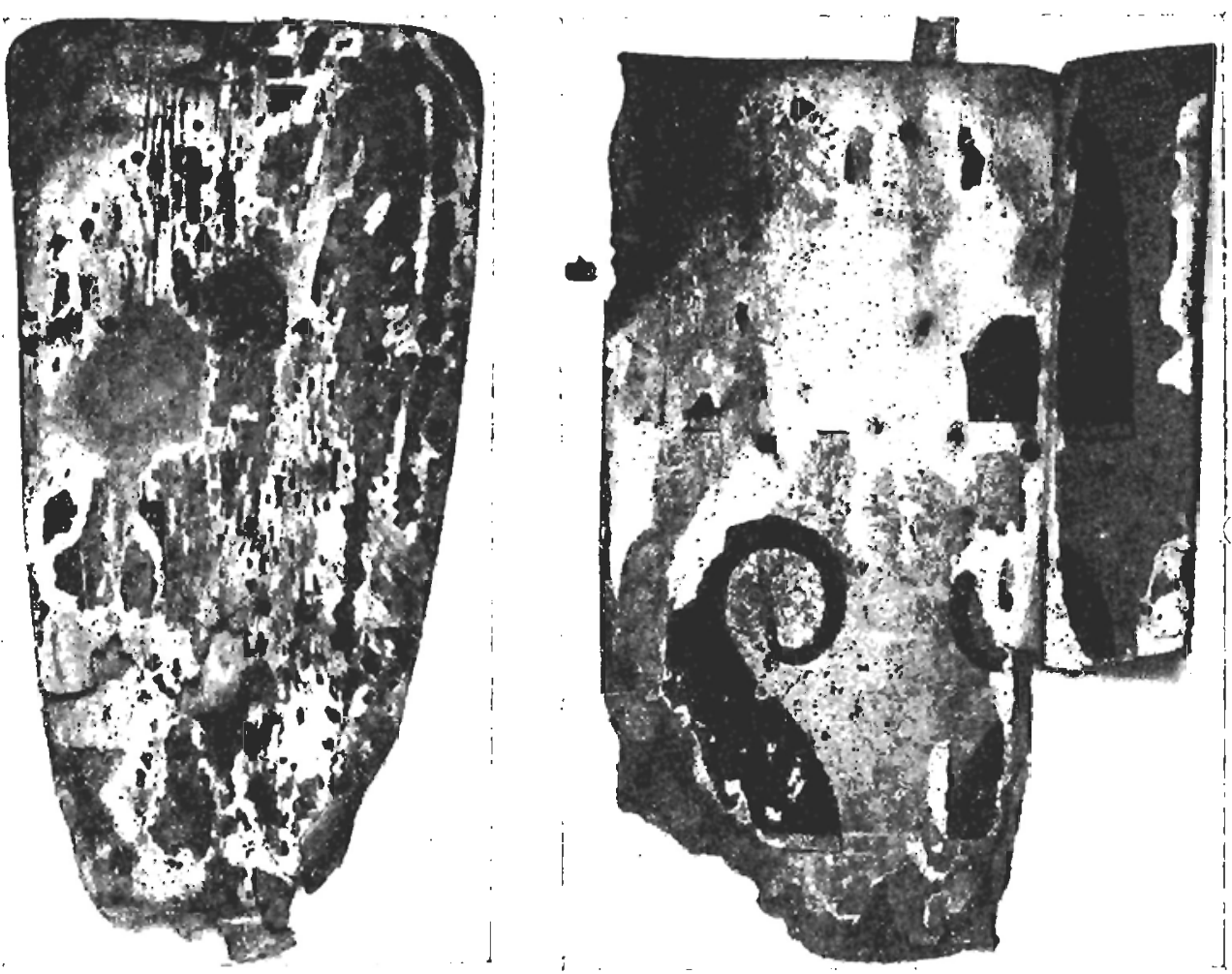

Fig. 8a-b.-Escudos de madera de cedro. Jorrados con pergamino, yeso y pintados heráldicamente. Procedentes del Monasterio de Salvalor de Oña Burgos, a: Real Armeria, Madrid (D 59), ca. 11901200. b: Real Armcría (D 60), ca. 1200. Folo amablemente cedida por el Parimonio Nacional, Palacio Real.

del licmpo, escudos largos (otros son almendrados), con sus guarniciones y refuerzos de metal (hierro), estilo peculiar en esta época. Un tipo precioso de escudos se expone en la Real Armería (D 59 y D 60), procedentes del Monasterio de San Salvador de Oña, Burgos (Fig. 8a-b). El escudo D 59 tiene las medidas siguientes: largo, 1,15 m.; ancho, $0,62 \mathrm{~m}$. Fin su interior vemos restos de las manijas para embrazarlo, hechas de picl de ante y forradas con terciopelo carmesí, más restos de la correa para colgarlo del cuello. Este escudo es del siglo xıI; el otro, D 60, es de comienzos del xir. Ambos tienen sus paralelos en las ilus- 
Gladius, Vol. especial (1988), pp. 31-101 Actas del I Simposio Nacional

traciones de Las Canligas del rey Aljonso el Sabio, en El Escorial. Parece que el escudo D 60 ha pertenecido al Conde de Bureba.

Por falta de documentación es difícil comparar el armamento de la España cristiana con el de Andalucía. Sin embargo, ciertos detalles en el Beato de Santo Domingo de Silos, hoy en el Museo Británico, en Londres, terminado en 1109, indican influencia del mundo oriental o del hispano-musulmán. Respecto a Andalucía, de esta época también podemos observar a la Sicilia normanda, con su mezcla de elementos bizantinos, musulmanes $y$, en cierto grado, normandos (de Alemania), a pesar de que también entre la Sicilia musulmana y la Andalucía hispano-musulmana existen diferencias notables.

Es indispensable estudiar el armomento ecuestre usado en esta época. Si contemplamos el armamento de los caballos en los siglos Xı y xiıl y lo comparamos con el del siglo anterior, observaremos que aún en el siglo XiI este armamento es bastante sencillo, con estribos simples y espuelas sencillas, pero grandes y similares a las usadas por los moros de Andalucía (ejemplar árabe en el Museo Arqueológico en Cáceres).

El lípico acicate moro se observa bien en el ms. mozárabe de Burgo de Osma, de 1086. El mismo tipo se ve en el ms. de Domingo de Silos, en el Museo Británico, de 1109. Las sillas parecen de dos tipos: uno llamado andaluz y otro llamado gallego, ya conocido por El Cantar de Mio Cid. Es difícil su distinción en las ilustraciones. Los tipos representados en las dos Biblias catalanas se encuentran también en Europa occidental, por ejemplo, en el tapiz de Bayeux, pero se diferencian de las sillas del Becto de Pierpont-Morgan Library, en Nueva York, del comienzo del siglo XIII (Fig. 9). Aquí vemos la silla cerrada del tipo nuevo, que va a dominar en el siglo xiı. Los caballos representados en las dos Biblias catalanas y en el relieve de Ripoll no tienen cobertura. Después de mediados del siglo xin - por ejemplo, en los sellos de los condes de Barcelona y reyes de Aragón-, los caballos ya vau protegidos con testeras, probablemente de cuero bollido, con una cobertura larga para cubrir el cuerpo. Probablemente, éste es de cuero crudo o una clase de tela fuerte. De malla parece ser la cobertura larga en un capitel del claustro del Monasterio de Santa María de l'Estany (Bages) (siglo xiı). El caballero aquí representado es un noble con loriga, escudo con heráldica y en forma de "U» y larga lanza. Con este documento estamos ya a las puertas del siglo XıI, siglo en el que domina la cobertura larga, de malla de hierro, llamada en las fuentes literarias «loriga para el caballo». Probablemente este tipo de cobertura sea más corriente en España que en otros países occidentales, pero no es desconocido al menos en Inglaterra (Painted Chamber in Westminster), Francia, Flandes o Alemania. Al final del siglo xiI aparecen algunos de los elementos que van a ser 


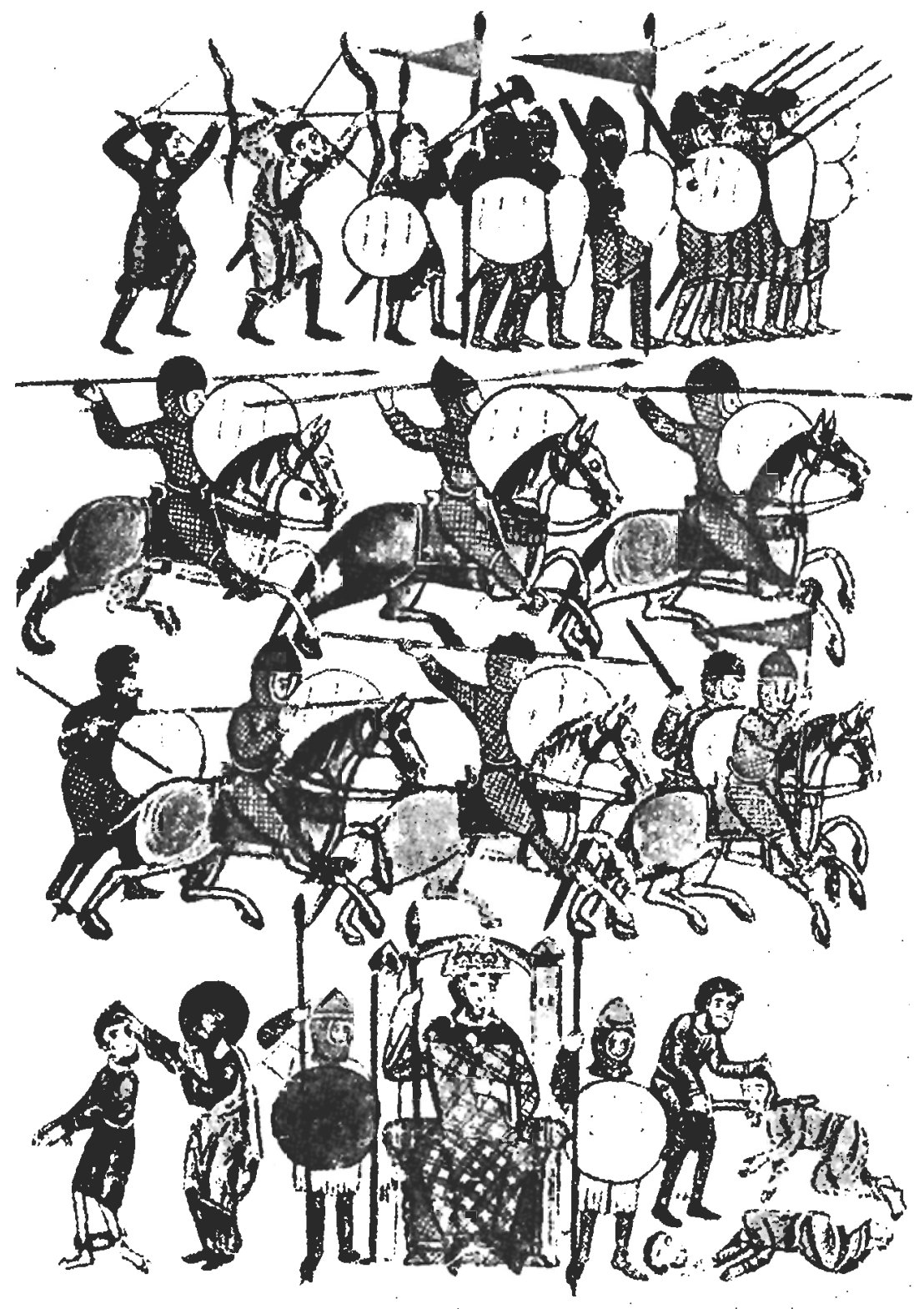

FiG. 9.-Inlantería y cahalleria. Bealo Mozárabe, siglo XIII, Pierpont-Morgan Library, Nueva York. Abajo: Nabucodonosor II decapilando 'nt'migos. 
característicos en el armamento del siglo XIII, el siglo en el que culminan las grandes Cruzadas de San Luis a Tierra Santa y el siglo de la auténtica Reconquista de España.

\section{LA RECONQUISTA y SUS ARMAS. \\ «Las Cantigas» de Alfonso el Sabio}

En el siglo xinl nos encontramos con un material rico, parte de carácter arqueológico, parte de carácter pictórico y literario. Estos últimos grupos de material se encuentran en especial en Castilla, Cataluña y Navarra, pero también en Andalucía hay alguno. La fuente más importante es el ms. iluininado "Las Cantigas» del rey Alfonso el Sabio en el Real Monasterio de El Escorial (T-I-1), de entre 1253 y 1287. Otras fuentes de importancia se encuentran en Cataluña y Navarra.

Las Cantigas, documento monumental y auténtico, nos muestran con detalle el armamento de la época de Alfonso el Sabio y sus hijos en toda la Península. Los documentos en Cataluña son varios; de gran importancia son las pinturas murales del Salón del Tinell, con los ejércilos de Jaime el Conquislador, el otro gran personaje en la Reconquista del siglo XII1; en el Museo de Arte de Barcelona están representadas, entre otras, la conquista de Mallorca por Jaime el Conquistador; el sitio de Palma, con el campamento del rey Jaime frente a la ciudad de Mallorca, procedente de la Casa de Berenguer d'Aguilar, del Carrer de Montcada, además de otros documentos artísticos, por ejemplo, varios frontales y retablos de Barcelona, de Mallorca y distintos lugares catalanes (Fig. 10). Existen también muchos documentos, esculpidos en piedra o mármol, en claustros e iglesias de Cataluña.

Las fuentes litcrarias de esta época son riquísimas tanto en Castilla como en Cataluña, con sus crónicas, inventarios, contabilidad y poesías.

En el sur de la Península nos encontramos con la influencia morisca, parte de los marroquíes, parte de las tribus berberiscas, con su caballería ligera del desierto. En el norte, la influencia nos llega por dos conductos: Cataluña, con Aragón y Valencia, la recibe de Francia, particularmente de Provenza, pero también de Italia del Norte, con Lombardía y Toscana; Navarra, por otro lado, está influida por el sur de Francia y de Borgoña. Las grandes Cruzadas, las últimas, las de San Luis de Francia, con sus fracasos en 1250 , también la recibían, respecto al armamento, particularmente el defensivo, de Occidente. Asimismo, de Sicilia, con su mezcolanza de normandos, bizantinos y musulmanes, especialmente de Tunicia, llegaron a la Península sus influjos, especialmente a Al-Andalus y a Murcia. Muchas de estas influencias se refieren a temas 
poliorcéticos, con las máquinas de guerra, por ejemplo. Los muslimes de Sicilia y de Tunicia eran grandes especialistas en la construcción de estos aparatos. La influencia musulmana se ve con toda claridad en las ilustraciones de la época. En España, el rey Alfonso el Sabio nos ha

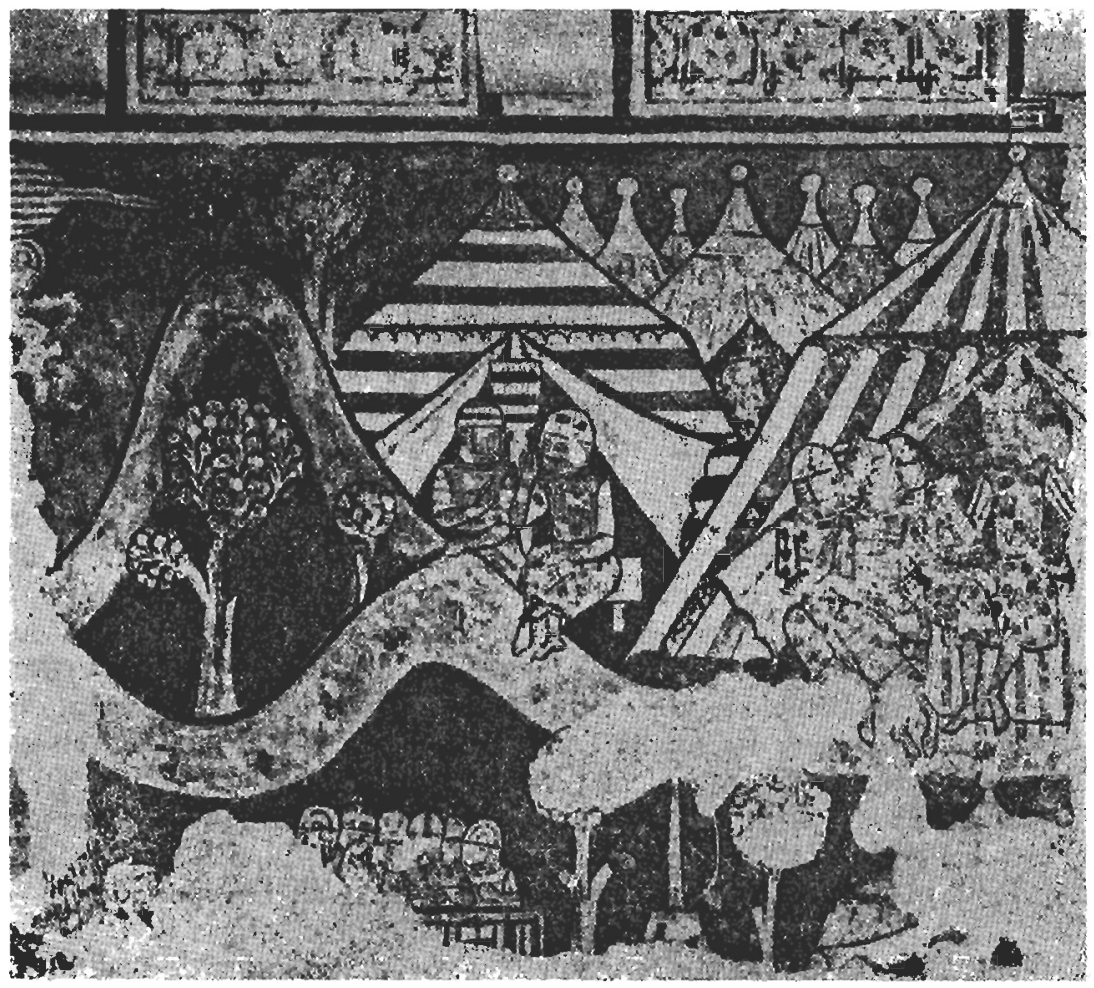

FIG. 10.-Campamento del rey Jame I el Conquistador frente a la ciudad de Mallorca. Pintara mural de la casa de Borenguer d'Aguilar, del Carrer de Montcada, Barcelona, siglo XIII. Museo de Arte, Barcelona.

dejado un ejemplo de su artillería con el trabuquete, construido por los sarracenos frente a Constantinopla. En su legislación, este mismo rey prohíbe vender madera a los sarracenos si ésta estaba destinada a la construcción de máquinas de guerra (Fíg. 22). 


\section{LA DOCUMENTACIÓN ARQUEOLÓGICA de la época de Alfonso el Sabio}

El suelo de gran parte de Europa ha dado material arqueológico en forma de espadas, cascos, restos de cotas de malla, hierros de lanza, flechas y virotas de ballesta. ¡No así en España! Hasta la fecha, casi nada nos ha descubierto de la época medieval. Pero lo poco de la época que nos ha dado tiene la gran ventaja de que son objetos muy bien documentados en las fuentes escritas, ya que son históricos. Los panteones de los reyes y príncipes del siglo XIII nos muestran una pequeña serie de espadas, parte de lujo, parte de guerra. Además, las espadas vienen acompañadas por espuelas de hierro dorado y con ataujía en oro y plata. Pertenecen a las mejores espuelas medievales de Europa. Esta combinación de espadas y espuelas en las tumbas tienen su explicación en que eran los objetos más importantes para el joven caballero en la ceremonia de su espaldarazo. Así, las tumbas de San Fernando en la catedral de Sevilla, Sancbo el Bravo en la catedral de Toledo, los presuntos objetos de Juan de Tarifa en Toledo, más Fernando de la Cerda en Las Huelgas, cerca de Burgos. En tanto que en otros países, en este siglo, vemos el gran yelmo de forma de «tonel» como auténtica pieza para la guerra, o como ornamento y decoración en la capilla funeraria, esta costumbre, al parecer, no ha sido corriente en España. Solamente dos ejemplares funenarios son conocidos por el autor: el bacinete del tipo de Milán, en el Museo Arqueológico de Burgos, y el gran bacinete hecho por Pedro del Campo, en Pamplona, ordenado por la madre del príncipe Carlos de Viana en 1425 para su capilla en la catedral de Pamplona, hoy en el Museo Provincial de Arqueología, asimismo en Pamplona.

Antes de examinar estos objetos quizá fuera conveniente observar y estudiar algunas de las batallas famosas de la Reconquista: La batalla de Alarcos, en 1195, fue un fracaso para Alfonso VIII frente a los moros. Sus guerreros, sin duda, han sido armados con lorigas del tipo de los relieves de San Vicente en Avila (Fig. 6): larga loriga de mallas de hierro, con mangas largas, almófar con ventalla y encima del almófar una cervellera de hierro (o de cuero bollido); escudos almendrados del tipo de los dos existentes en la Real Armería; espadas largas y tajantes, jabalinas arrojadizas, lanzas largas para caballería, así como ballestas. La gran y decisiva batalla de Las Novas de Tolosa, en 1212, fue una gran victoria para Alfonso, un encuentro entre Europa y Africa, con victoria para la primera. Conocemos muchos detalles sobre esta batalla debido tanto a las fuentes cristianas como a las moras. En este combate, el armamento no ha variado mucho del de Alarcos; la ballesta hizo gran papel, así como también, por parte mora, los arcos árabes o turcos. Des- 
pués de la batalla, los guerreros de Alfonso tenían montones de virotes para cocinar sus comidas. En esta batalla, los caballeros de Alfonso VIII, probablemente, han protegido sus caballos con coberturas de malla, así como con lorigas, testeras de hierro o cuero bollido, con protección en forma de rejacillas, para los ojos y tubos para las orejas, como se puede ver en las ilustraciones de la época (Fig. 26). Las armas ofensivas han sido espadas, grandes y tajantes; lanzas largas para caballería, jabalinas para infantería; además utilizaron «mazas turcas», del estilo fabricado en Damasco, probablemente de las usadas por los Templarios, que participaron en esta batalla. El armamento de los moros también consistió en lorigas de malla, cascos en forma de cervelleras, más o menos como las cristianas, y espadas fuerles; sin embargo, las lanzas eran de otros lipos: largas pero ligeras, con puntas pequeñas y prismáticas, aptas para una caballería ligera. Además de ballestas han usado arcos y flechas «turcos» y «árabes» (Fig. 25a-b). Es posible que, entre los moros, ciertas personas de la clase alta hayan sido vestidas al estilo típico musulmán, como se nota en Las Canligas, con turbantes encima de sus cascos y con marlotas encima de sus lorigas, de brocado de los famosos telares de Granada (Fig. 27). Sus caballos no fueron protegidos por lorigas de malla, como los de los cristianos, ya que esta caballería era más ligera y móvil que la de los cristianos. No conocemos armas arqueológicas ni de los ejércitos de Alfonso VIII ni de los moros. Su tumba en Las Huelgas, en Burgos, fue robada en el siglo xIx por las tropas francesas, al mando de José Bonaparte en la guerra napoleónica.

\section{Objetos arqueológicos de la Reconquista}

El nieto de Alfonso VIII, Fernando III, el Santo, proseguía las guerras contra los moros, conquistando región tras región, al mismo tiempo que su colega el rey Jaime de Aragón, con el nombre de «El Conquislador», luchaba contra ellos en Baleares y Valencia, logrando conquistar todos los lugares con su ejército de tierra, su poliorcética y sus naves de guerra. De San Fernando se conservan algunos objetos históricos de gran valor: su espada, sus espuelas y un trozo de su capa, todo procedente de su tumba en la catedral de Sevilla.

La espada de San Fernando (Fig. 11), expuesta en el tesoro de la catedral de Sevilla, tiene un montaje de plata dorada, en forma de portaespada, del siglo xv; hoy día se utiliza como cruz para ceremonias. Existen algunas fuentes literarias sobre esta espada. A pesar de la incuria de los siglos, casi hasta nuestra época, con muchas reparaciones y mucha limpieza, su tipo puede fijarse sin duda en la primera mitad del 


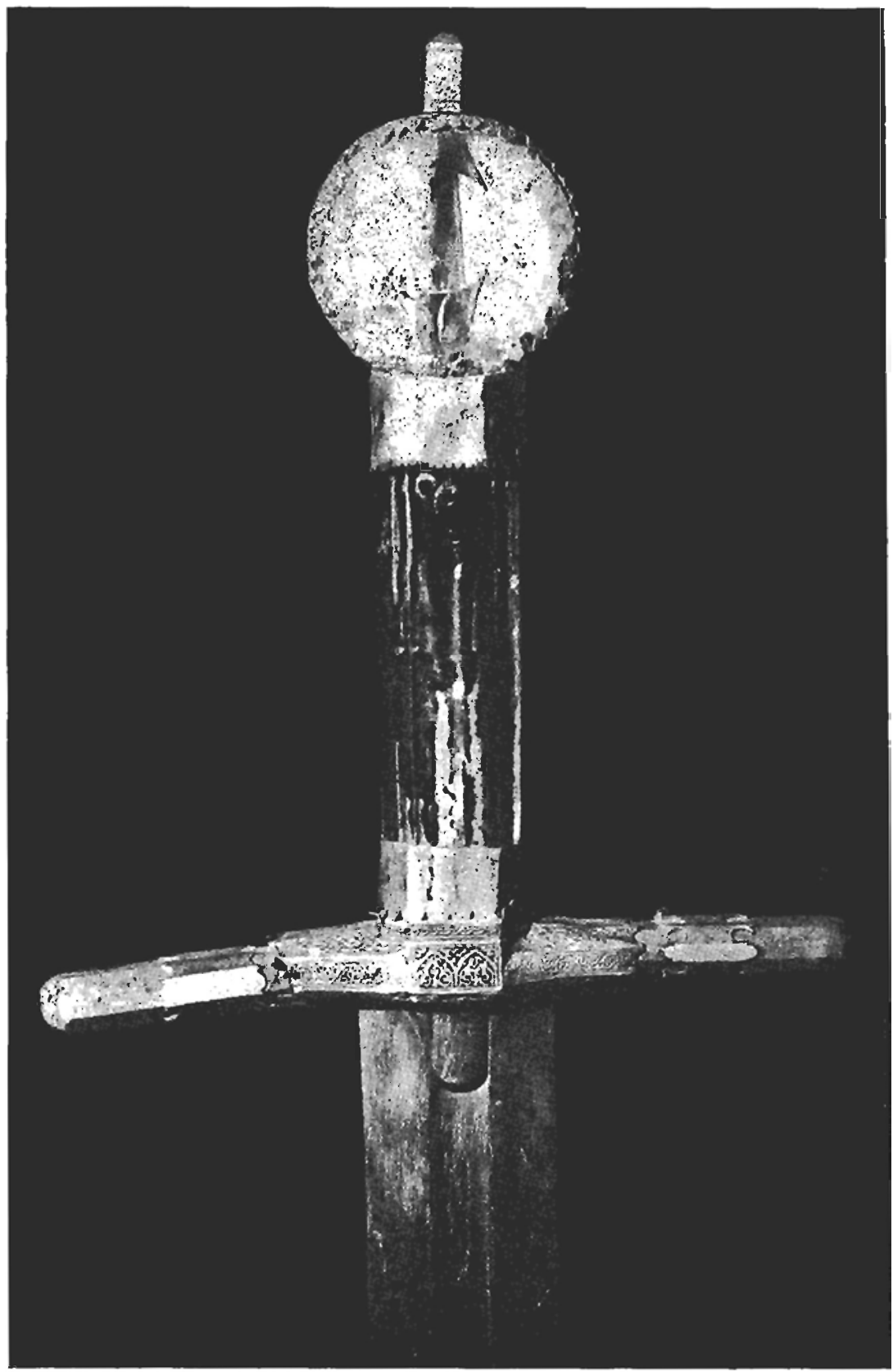

FIG. 11.-Espada de ceremonia de San Fernando, empuñadura de crislal de roca, ágata y plata, ca. 1240-50. Catedral de Sevilla. 
siglo xul, aproximadamente hacia 1240-50. Tiene una larga historia, probablemente todavía no comprobada. Dejando aparte la hoja, que puede tener más edad, es una espada de ceremonia, no de guerra. Es muy probable fuese fabricada por orden del rey para las solemnidades después de la rendición, en conmemoración de la victoria. El pomo está hecho de dos discos de cristal de roca con los lados céntricos aplazados. Las dos partes están unidas con plata adornada con ornamentos mudéjarcs. La decoración es modesta. En 1454, el orfebre Juan de Talavera prolongó su espiga. De esta época se supone es el espigón de plata encima del pomo. El puño también es de cristal, con un tono rojizo-amarillento algo parecido al granate. Los gavilanes son de ágata cornalina y tienen aplicaciones de plata con ornamentos moriscos. Del mismo modo, la cruz es de plata con ornamentos. Desgraciadamente, la hoja ha sufrido demasiadas limpiezas y pulimentos durante los siglos, que han conseguido casi borrar la inscripción en la canal, por lo que no se puede leer. Al parecer, hay restos de una cruz, parecida a la de la Orden de Calatrava, con una cadena. Su vaina original no existe, pero se la conoce por descripciones de la época. Además es muy parecida a la vaina de la espada de San Fernando o Alfonso el Sabio (G 22), en la Real Armería en Madrid, estilo mudéjar con piedras preciosas (Fig. 12). Cuando en 1554 fue abierta la tumba por orden de Felipe II, encontraron en ésta otra espada al lado del rey. Esta, al parecer, ya no existe. Sin duda fue una espada para la guerra.

En la misma tumba se encontraron también sus espuelas de hierro dulce, con ataujía de oro y plata, con castillos y leones y en forma de acicates.

Todo esto se encuentra hoy en la Real Armería, en Madrid. Este museo tiene otra espada que se refiere al Santo Rey (Fig. 12). Es conocida como espada de San Fernando o de Alfonso el Sabio. Cronológicamente puede pertenecer a ambos reyes, aunque más probablemente a don Alfonso. Esta espada debe también considerarse como de ceremonia, y quizá está hecha para la pretendida colonación en Roma de $\mathrm{Al}$ fonso el Sabio como emperador. La espada también tiene su historia especial. Según el estilo de su empuñadura, se parece a las espadas hispano-árabes con influencia de Damasco o de Bagdad. Procede del tesoro de los Reyes Católicos en el Alcázar de Segovia. Está mencionada y detalladamente descrita por Gaspar de Bricio en el «Inventario de este tesoro», de 1503. Dice el autor que la vaina está compuesta por cinco placas de plata dorada en cada lado, ornamentada en estilo mudéjar, con filigrana fina, con piedras preciosas y con camafeos antiguos romanos. Bricio la llama «La Joyosa de Belcortar de Roldán», casi poniéndola en contacio con la historia de Carolus Magnus. Hoy, la mayoría de las 
Gladius, Vol. especial (1988), pp. 31-101 Actas del I Simposio Nacional ISSN 0435-029X

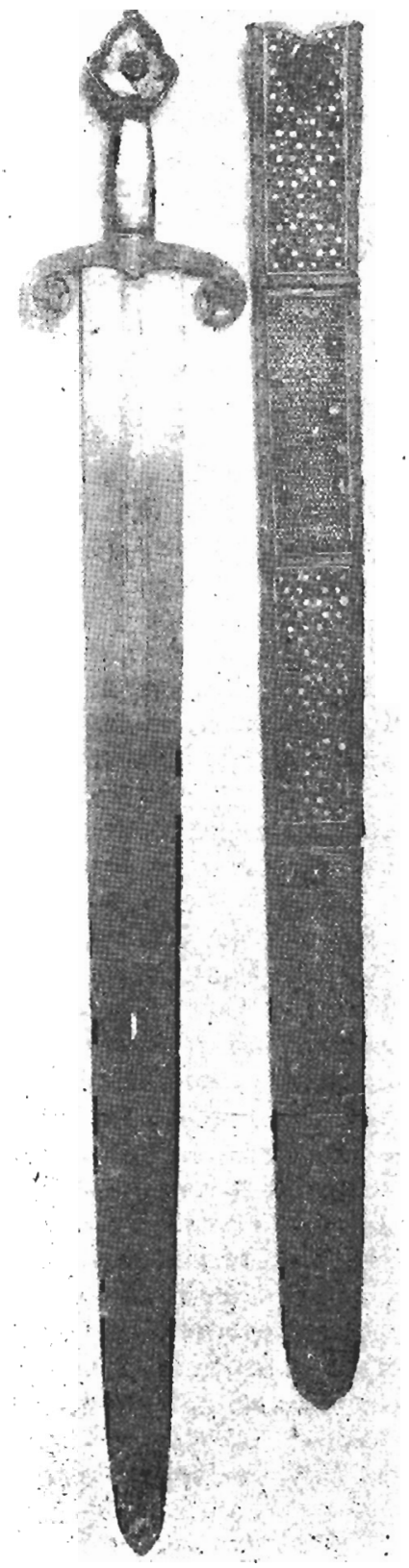

Fici. 12.-Espada de Allonso el Sabio. Para ceremonias, plata dorada con filigrana, vaine de plata dorada con filigrana, piedras preciosas y camaleos antiguos romanos. Red Armería (G 22). Concedida por el Patrimonio Nacional. 
piedras preciosas han desaparecido, pero algunos de los camafeos siguen aún en su lıgar. Las placas van unidas por listones de plata dorada con ornamentos de estilo mudéjar, estilísticamente recordando al estilo de la parte mudéjar de la Giralda, de la catedral de Sevilla. Aunque todavía no ha sido posible documentarlo, parece probable que esta espada sea obra de algún orfebre de Sevilla. Según Ibn-Said, la Sevilla de entonces tuvo fama por sus orfebres y espaderos. El tipo es conocido en Las Cantigas. La hoja es ancha y blanda, con decoraciones en forma de círculos concéntricos, y no sirve para guerra. Es raro encontrar camafeos romanos engastados en armas medievales. El arte glíptico antiguo se había perdido en la época medieval, pero resucitó durante el Renacimiento. ¿Pueden estos camafeos tener alguna relación con los camafeos en la corona dorada de Alfonso el Sabio? ¿Pueden tener alguna relación con las pretensiones del rey Alfonso a la Corona imperial de Roma?

Sería interesante comparar la espada G 22, en la Real Armería, con la corona de plata dorada encontrada en la tumba de su hijo y sucesor Sancho IV el Bravo, cn la catedral de Toledo (Fig. 13). Es una corona sencilla de tipo romano-bizantino, en la arqueología romana generalmente llamada corona mural.

En la época helenístico-romana existen estatuas femeninas, mitológicas y entronizadas con coronas de este tipo, especialmente en Asia

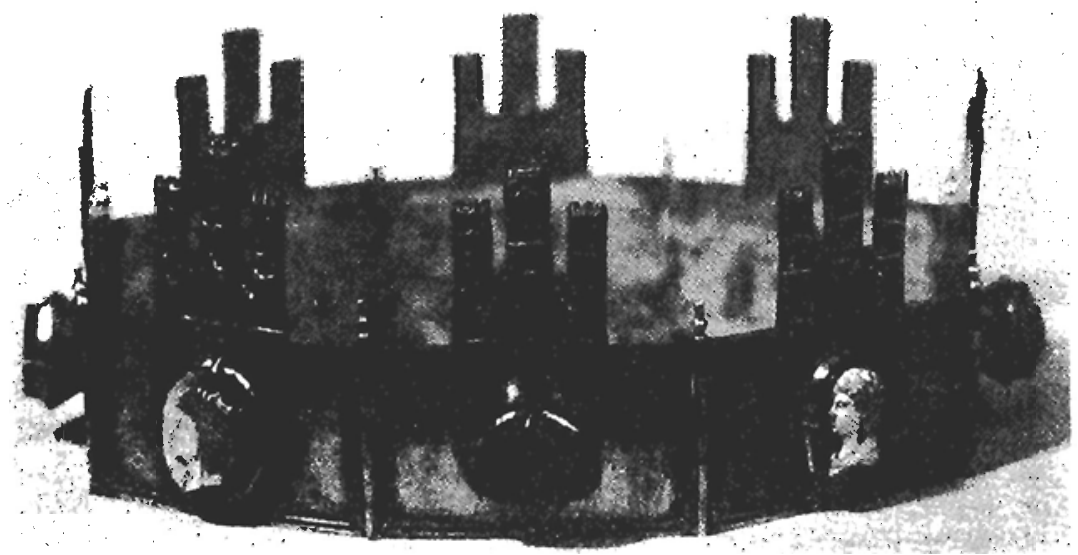

Fic. 13.-Corona del rey Alfonso el Sabio, becba mies de 1284. De plata dorada, con ocbo placas, cada una coronada con un castillo (¿o una catedral gótica?); en el centro, un zafiro grande en las cuatro placas, y en las otras cuatro un camaleo antiguo romano. Encontrada en la tumba del rey Sancbo IV el Bravo. Catedral de Toledo. 
Gladius, Vol. especial (1988), pp. 31-101

Menor (Esmirna, Efeso). La tradición continúa durante las épocas bizantina y románica, como se nota en el arte otoniano e incluso en el románico en Cataluña. La corona de la tumba de Sancho el Bravo está formada por ocho placas oblongas, sujetas entre sí por charnelas desmontables; las placas están coronadas por castillos ( ¿o por catedrales góticas?) fundiclos al parecer en una placa en el mismo molde y doradas. Cuatro de las placas tienen un gran zafiro engastado en el centro, y otras cuatro un camaleo romano antiguo de alta calidad, probablemente la parte más valiosa de esta corona. Dos de estos camafeos representan a emperadores romanos de la dinastía Julio-Claudia, y los otros dos a mujeres, posiblemente de carácter mirológico.

Sería interesante poseer un análisis de los camafeos de estos objetos. ¿Está Alfonso el Sabio bajo influencia de San Luis de Francia? En Cabinet de Médailles, en Bibliotbèque Nationale de París, se encuentra el más grande y más importante camafeo del mundo, de la época augustea, con representaciones de la Casa Julio-Claudia, con el emperador $\Lambda$ ugusto y su familia, con Tiberio y con la aposteosis del emperador Claudio en medio de casi toda la familia imperial de esta Casa, glorificando la Casa Imperial. Este camafeo fue traído a Bizancio por el emperador Constantino y perteneció durante varios siglos a la Casa Imperial de Bizancio. El emperador Baldovino II (1237-61), rey de Jerusalén, se lo regaló a San Luis de Francia para instigar a este monarca el comienzo de las Cruzadas y liberar la Ciudad Santa de las manos de los infieles. Tiene una larga historia, que pasa por los Papas y el Vaticano antes de llegar a su destino final en la Bibliothèque Nationale de Francia. Respecto a la corona de Alfonso el Sabio es probable, además, que el Rey Sabio, un hombre erudito y dedicado a estudios científicos sobre el antiguo Imperio romano y la época imperial de Carolus Magnus, haya sido inspirado por la famosa Corona Lombarda de Hierro, en la catedral de Monza, en Lombardía. Esta corona, sencilla, pero preciosa, de oro con piedras preciosas y esmaltes coloreados, construida sobre una base en forma de un anillo de hierro, según la leyenda de un clavo de la Santa Cruz, desempeñó un papel importante en el Sagrado Imperio germanoromano durante siglos. Carolus Magnus, después de su conquista de Lombardía en el año 774, se autocoronó con esta corona lombarda como rey de Lombardía, y en el 800 como emperador de Roma. Los soberanos germano-romanos, durante siglos, fueron coronados con este símbolo de su dignidad. (Hasta el mismo Napuleón se autocoronó en 1805, en Milán, con esta corona, lo mismo que hizo el emperador Fernando de Austria en 1838.) Alfonso el Sabio soñaba con el Imperio romano, y sus sueños no estaban basados en pura imaginación. El título de emperador, usado por los reyes de Alemania - los sucesores de Carolus Mag- 
nus-, estaba entonces vacante, y Alfonso tenía por parte materna el mismo derecho al título de emperador como otros de los pretendientes. Por causas internas e internacionales hubo por fin de desistir de sus sueños. No eran realizables.

La corona del Rey Sabio tiene parecido con algunas de las ilustraciones que nos muestran a emperadores germano-romanos, por ejemplo, los emperadores Otto II y Otto III, del Sagrado Imperio germanoromano (Otto II, por ejemplo, en Registrum Gregorii, en Trier), y en otras del arte otoniana y otras más tardías. Pertenece según su tipo a estos círculos de signos de dignidad.

Es tentador poner su corona en contacto con la del segundo testamento de Alfonso el Sabio de 22 de enero de 1284, en Sevilla. En éste dice al rey: «E mandamos otrosi que... las coronas con las piedras e con los camafeos e sortijas e ot ras cosas nobles que pertenecen al rey, que le haya todo aquel que son derecho nos heredare el nuestro sennorio mayor de Castilla e Leon...» ¿Pertenecen la espada y la corona, con sus zafiros y camafeos romanos, a un conjunto típico de coronación? ¿Y tienen ambas partes relación con la intención de coronación en Roma? ¡Es muy probable!

Véase para estos problemas Bonifacio Palacios Martín, Los simbolos de la soberania en la Edad Media española. El simbolismo de la espada. en «VII Centenario del Infante Don Fernando de la Cerda», Jornadas de Estudio (Ciudad Real, abril 1975). Instituto de Estudios Manchegos, 1976, págs. 274 y ss. Y para la corona de Alfonso el Sabio, J. María Relanzón García-Criado, La corona y la espada de Sancho IV de Castilla, en «Real Academia de Bellas $\Lambda$ rtes y Ciencias Históricas de Toledo, Toletum» XXXIII-XXXIV-XXXV, 69-70-71, n. 2 (Toledo, 1959), págs. 1-8.

San Fernando poseía, además, otra espada famosa: La Lobera (Real Armería, G 21). Esta espada, hoy en la Real Armería en Madrid, solamente tiene su hoja de la época del Santo Rey. Está privada de su guarnición sle plata slorada y con esmaltes, conocida por las descripciones de la época. La empuñadura que tiene hoy fue puesta por orden de Carlos V a comienzos del siglo xvr y está realizada por el espadero del rey en Toledo, Salvador de Avila, que puso su punzón en el recazo, también hecho por él (Fig. 14). En el famoso Inventario iluminado, de ca. 1540, esta espada figura con su nueva empuñadura y con todas las modernizaciones que mandó hacer el emperador. El inventario de Gaspar de Bricio sobre el tesoro de los Reyes Católicos en el Alcázar de Segovia, en 1503, es minucioso y dice expresamente que la espada tenía la empuñadura de plata, el pomo era de hierro plateado y tenía los blasones de Castilla y de León. La hoja todavía conserva su inscripción en la canal, a un lado: SI, SI, al otro NO, NON, correspondiente al lema del Rey Santo en «Sobre Noble- 
Gladius, Vol. especial (1988), pp. 31-101 Actas del I Simposio Nacional ISSN 0435-029X

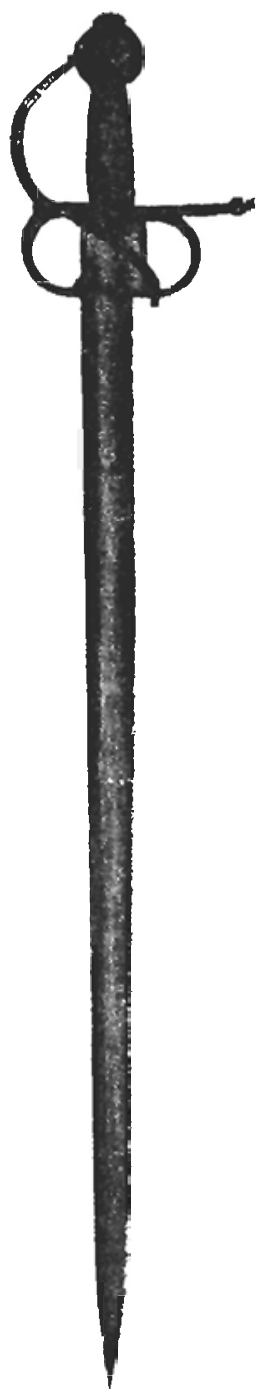

FIG. 14.-Espada de San Fermando, probablemenle "La Loberan, Real Armería ( $G 21)$. La boia con inscripción: SI, SI y NO, NON. Privado de su empuñadura de plala. La de abora es de la época de Carlos $V$ y becho por al espadero ioledano Salvador de Avila. Reproducida en "Inecniario iluminadom, de 1540, con empuñadura aclual. 
za y Lealtad»: "Tu Sí sea Sí y tu No sea No», continuando con los deberes de un rey frente a sus vasallos. A pesar de las objeciones que han hecho investigadores extranjeros, que no aceptan una inscripción que se corresponde tan poco a la época de las grandes Cruzadas en el siglo xıIL, es probable que el erudito Conde de Valencia de Don Juan tenga razón en su definición en el catálogo sobre la Real Armería (Madrid, 1898), pág. 201, así como en sus explicaciones y referencias a la literatura de la época del Rey Santo.

En la época de este rey y de sus hijos, la espada era bien conocida. En ese sentido nos informan las crónicas de la época. Fue parte de la herencia del hijo menor del rey. Según las fuentes del siglo xIV, se utilizó en la batalla del Salado, en 1340, por el nieto de San Fernando, don Juan Manuel. Se la consideró una espada de «Virtud», con calificaciones mágicas, forjada bajo ciertas constelaciones de las estrellas.

Otra espada de San Fernando era la conocida como La Colada, una de las espadas famosas de El Cid. En los Archivos de Simancas tenemos documentación sobre esta espada y su historia del siglo XIII, por lo menos hasta 1304. Existe algún error en su historia, y ha sido confundida con La Lobera. Está descrita en el inventario de Gaspar de Bricio en 1503 sobre el tesoro del Alcázar en Segovia. Pero poco después desapareció del tesoro de los Reyes Católicos. Se ha pensado en la posibilidad de que fuese robada durante la rebelión de los Comuneros. De este asunto no se sabe nada concreto. Parece lo más probable - pero todavía sin documentación auténtica- que haya sido esta espada, La Colada, y no La Tizona, la regalada por Fernando el Católico al primer Marqués de Falces, condestable de Navarra, Mosén Pierres de Peralta, en agradecimiento por sus méritos en el servicio del Rey Católico; hoy está expuesta en el Museo del Ejército bajo el nombre de La Tizona de El Cid. Esta espada tiene una hoja antigua sin ornamentación (al parecer). En los comienzos del siglo xvi se la ha modernizado, poniéndole una empuñadura de hierro en estilo típico español de los años 1500-1520, con una guarnición con pitones parecida a las espadas del Gran Capitán, Gonzalo de Córdoba, y ot ros conocidos personajes de estos años. El recazo está hecho al mismo tiempo que la empuñadura, característica de los años posteriores a 1500. Tambićn la inscripción en el recazo pertenece a esta época. La documentación escrita sobre la historia de esta espada fue quemada durante la Guerra Civil. Pertenece a los descendientes de los Marqueses de Falces y está depositada en el Museo del Ejército. Es probable que un análisis metalúrgico pudiese resolver el problema de las dos espadas que se conocen con el nombre de La Tizona de El Cid (Real Armería, G 180; Fig. 7).

En la catedral de Toledo también se conservan unas espadas históricas 
Gladius, Vol. especial (1988), pp. 31-101

Actas del I Simposio Nacional

"Las Armas en la Historia (siglos X-XIV)"

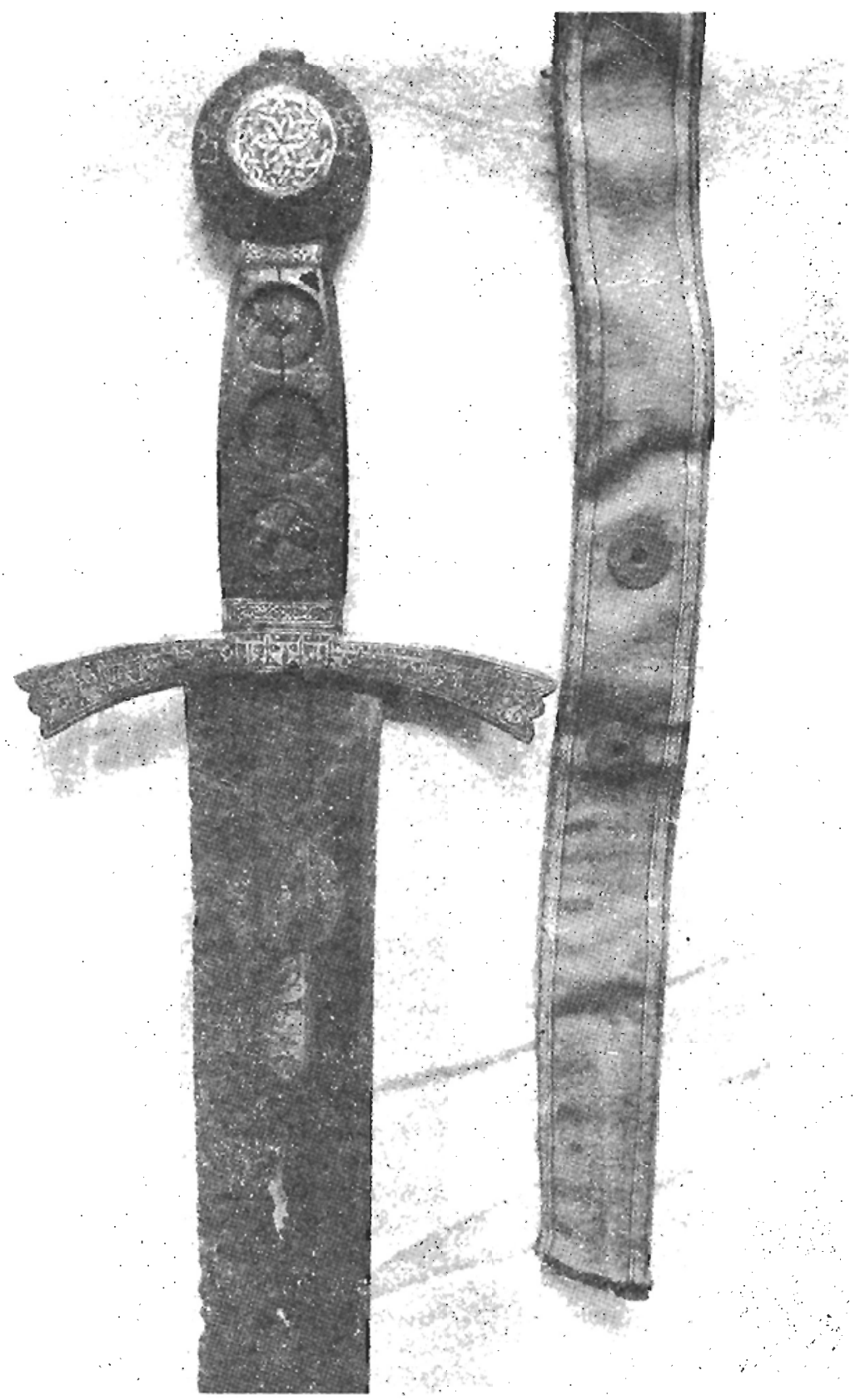

Vig. 15.-Expada del rey Sancbo IV el Bravo en su tumba en la catedral de Toledo. Empuñadura le bronce dorado, inscripciones callicas. Inscripción en latin con lelras lombardas an la boja, becbo con agua fueve, pero boy casi ilegible. Caledral de Toledo. 
Gladius, Vol. especial (1988), pp. 31-101 Actas del I Simposio Nacional

de esta época. De particular interés es la espada preciosa del rey Sancho IV el Bravo, hijo de Alfonso el Sabio y su sucesor en el trono en el año 1284 (Fig. 15). Hecha más para la guerra que para ceremonias, es una espada fuerte y preciosa, una de las mejores de la época medieval que existen del siglo xi1. La empuñadura es de bronce dorado y el estilo mudéjar, con inscripciones en letras cúficas, sin contenido, aunque se lee el nombre de Alah en la cruz. El estilo parece ser toledano. La hoja ha sido preciosa y es todavía de alta calidad, pero por desgracia está muy estropeada por oxidación en la tumba. Aún puede apreciarse en las partes menos deterioradas una inscripción hecha en letras lombardas, pero desperfecta y hoy ilegible. Está realizada con agua fuerte, probablemente una de las primeras inscripciones hechas por esta técnica, que en épocas posteriores fue tan usada en armaduras, hojas de espadas, partisanes para guardas imperiales y reales, especialmente en las épocas del Renacimiento y Barroco.

La vaina, con restos del cinturón, existe todavía, aunque es muy posible que este tahalí haya pertenecido a otra espada. Las espuelas encontradas en la tumba son acicates de hierro con ataujía en oro y plata, probablemente unas espuelas de las mejores de las existentes de la época medieval.

En esta tumba fue encontrada la corona de tipo bizantino-otomana, de plata dorada, con los camafeos romanos (Fig. 13).

A los mismos círculos pertenece otra de las espadas de la catedral de Toledo, la preciosa pequeña espada para ceñir, con empuñadura y guarnición de vaina, también en plata dorada y con los escudos heráldicos de León y Suabia (la heráldica materna) en esmalte (Fig. 16). Esta espada pertenece al tipo que en catalán se denomina «bordonença», pequeña espada para ceñir, elegante y preciosa, con un cinturón elegante, usado cuando el caballero está montado. La espada se adjudica al príncipe Juan de Tarila, hijo menor de Alfonso el Sabio. A Claude Blair, de Inglaterra, le cabe el honor de haber hecho esta referencia que, sin duda, es correcta. El escudo de León posiblemente indica no sólo su descendencia como nieto de San Fernando e hijo de don Alfonso, sino también la heráldica de los reyes de Castilla y León, pero es probable se deba a su nombramiento «como rey de León» en los desleales acuerdos entre el rey Dionis de Portugal y algunos de los rebeldes en la lucha y las intrigas por el trono de Castilla-León, al final del siglo xiri y comienzos del xiv, al morir Sancho IV, en 1295. Don Juan, el traidor de Tarifa, murió en el mes de junio de 1319 en la vega granadina, no en batalla, sino víctima de un ataque de apoplejía; con él murió su sobrino don Pedro de Toledo, el animoso espíritu de la Reconquista y el presunto dueño de las espuelas. Fue arrojado en un canal del río Genil por un grupo de jinetes moros, muriendo aho- 
Gladius, Vol. especial (1988), pp. 31-101 Actas del I Simposio Nacional

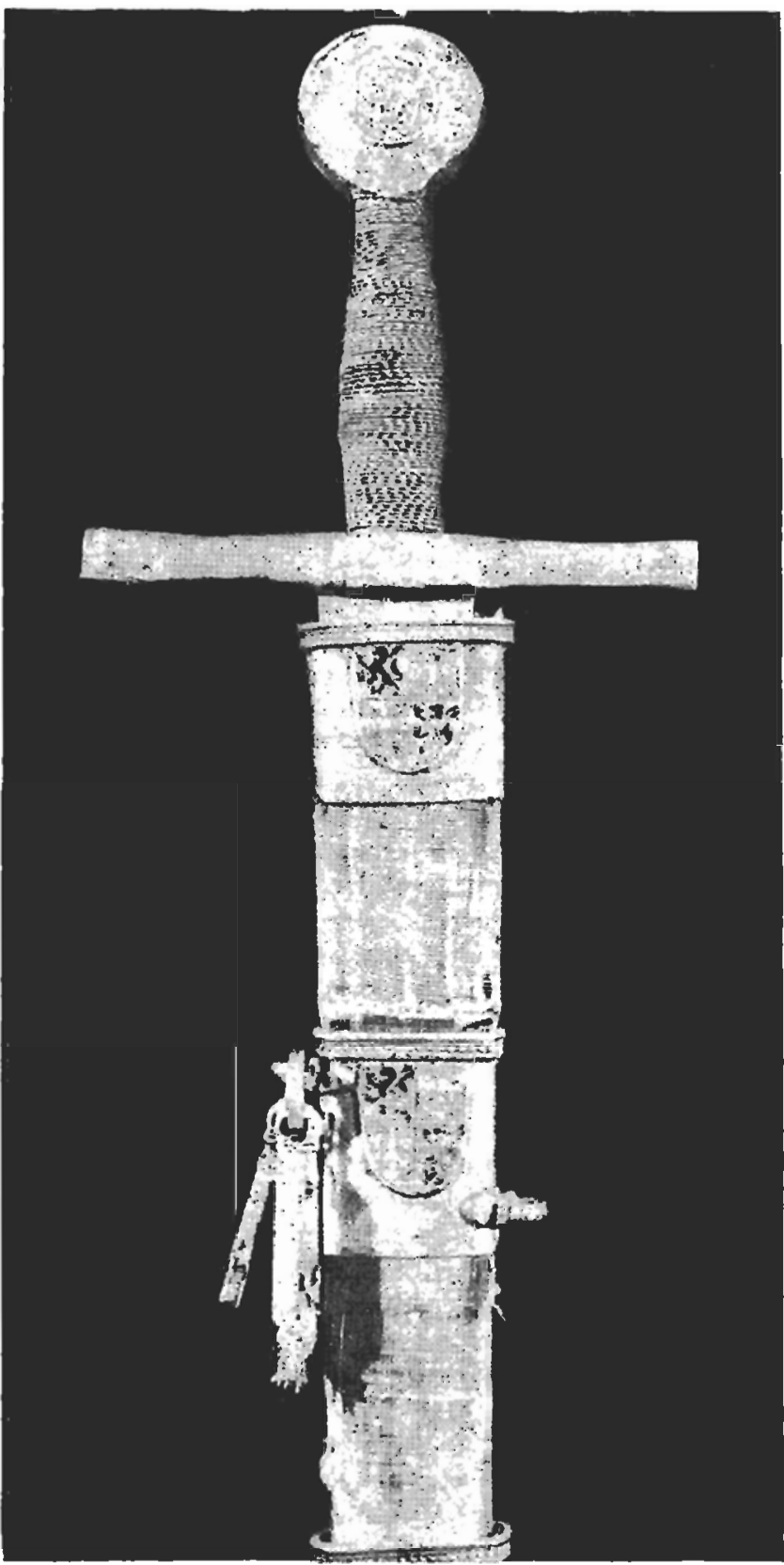

Fig, I6.-Espada para ceñir montado, probublemernte para centemenias. Sin duda ba pertenecido a luan de Tarila, que murió de apoplejio durante la batallo de Tarile, en 1319. Esculos de León y Suabia, hechos después de ca. 1300. 
Fig. 17.- Esprada pord geerrit, de Fermando de la Cerda, procedento de sal tumba en (l) Monuslcrio do las theselgas. Burgess. Anlos de 1275. Pomes de bronece.

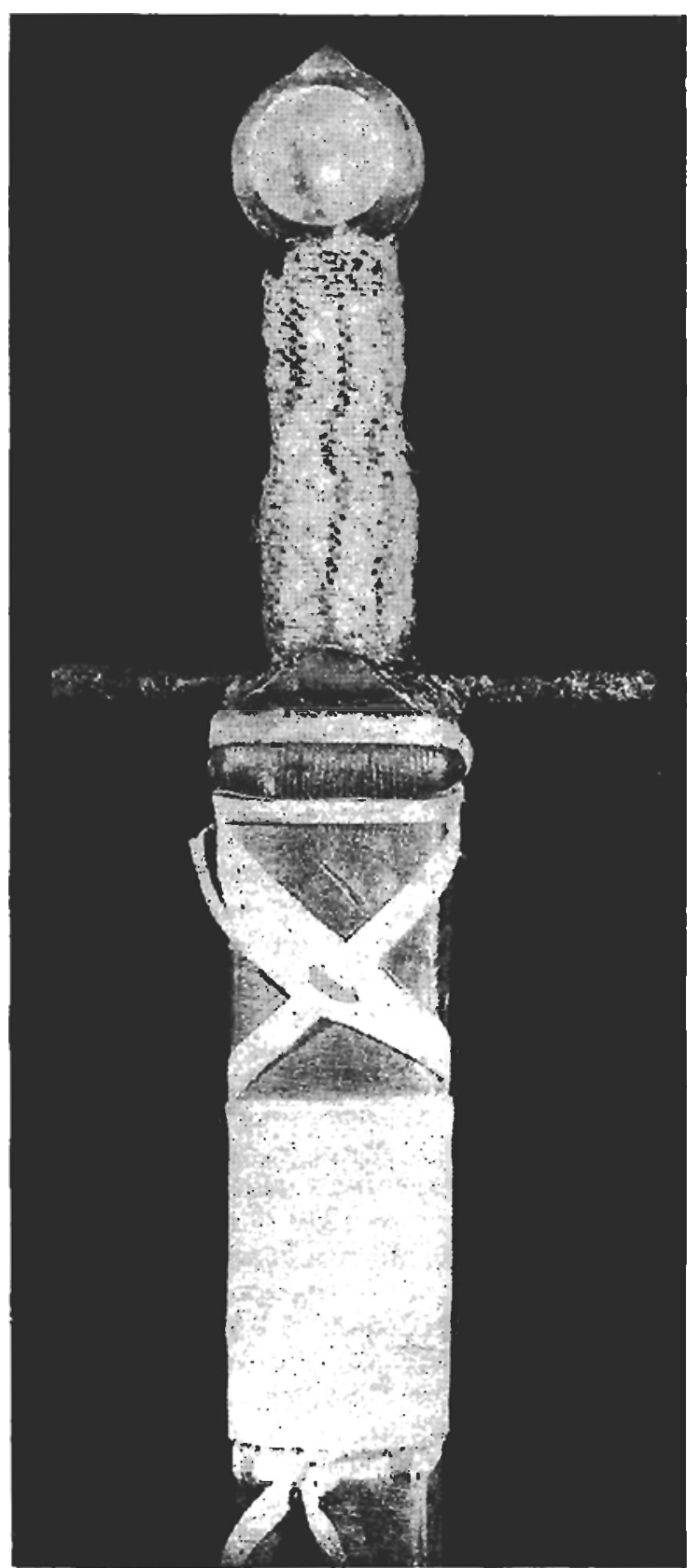


Gladius, Vol. especial (1988), pp. 31-101

gado. Los esmaltes de sus blasones pueden häber sido hechos en Valencia, ciudad que en aquella época tenía fama por sus esmaltes. El tipo de la espada tiene sus parientes en Italia, Toscana y Lombardía, especialmente con la espada del Can Grande della Scala en Verona, que murió en 1329.

En contraste con estas espadas reales y de lujo encontramos la espada preciosa y fuerte procedente de la tumba del infante Fernando de la Cer$d a$, hijo mayor de Alfonso el Sabio, hallada en su tumba en el monasterio de Las Huelgas, cerca de Burgos (Fig. 17). Es un arma sencilla de hierro con pomo de bronce, cuyo color, por oxidación, se ha transformado en un azul precioso. Todavía persiste el bobinado de hilo de seda en la empuñadura, con sus colores amarillo y rojo, ya muy gastados, pero aún conservados en sus franjas. Los gavilanes de hierro están algo comidos por la oxidación. De la hoja solamente quedan restos. La vaina, de badana, con un bolsillo de piel fina con dibujos en piel blanca, está bien conservada. Acompaña a la vaina un cinturón precioso, largo, de brocado de seda, oro y plata con perlas y una hebilla de plata dorada. En el cinturón pueden verse los escudos de Navarra, Francia e Inglaterra. Puede ser obra francesa, cuando, en 1269, el infante casó con Blanca de Francia, hija de San Luis; no obstante, también pudiera ser un trabajo de los famosos telares de Granada. Su tipo se asemeja a los bien conocidos cinturones de la Alhambra de Granada.

Es preciso que destaquemos la preciosa espada llamada de Santa $\mathrm{Ca}$ silda, hoy en el Instituto de Valencia de Don Juan, en Madrid (Fig. 18). Junto a la de Sancho el Bravo, pertenece a las más típicas de España, con una calidad parangonable a las mejores de Europa en este siglo. Ha sido conservada durante siglos por una familia noble de Briones (Logroño), cerca del histórico Haro. Posee fama por ser «de virtud», con calificaciones mágicas, especialmente cuando las mujeres tienen parto difícil. En su pomo, en esmalte de colores en ambos lados, puede verse una clase de heráldica parecida a los blasones del héroe de Sevilla en Las Cantigas, el Conde de García. Cronológicamente, puede fijarse esta espada hacia 1300 o muy poco antes. Sin duda ninguna, es obra española. Las inscripciones en el pomo son: Ave Maria gralia plena, y en los gavilanes: Dios es vencedor en todo. Amén, lema usado después de la subida al trono de los nazaríes en Granada en 1230 y utilizado por los caballeros cristianos en este reino. No tiene ninguna relación con la Biblia.

Otra espada histórica destacada es la espada llamada de San Marlín (Fig. 19), hoy en el Musée de l'Armée, en París, procedente de la colección de Georges Pauilhac, antes en la colección de José Estruch y Cumella, en Barcelona, en 1898, comprado en bloque por Pauilhac en París. Tiene una larga historia bastante complicada. José Estruch y Cumella compró esta espada al Gremio de los Cotoneros en Barcelona, en cuyo 
Gladius, Vol. especial (1988), pp. 31-101 Actas del I Simposio Nacional
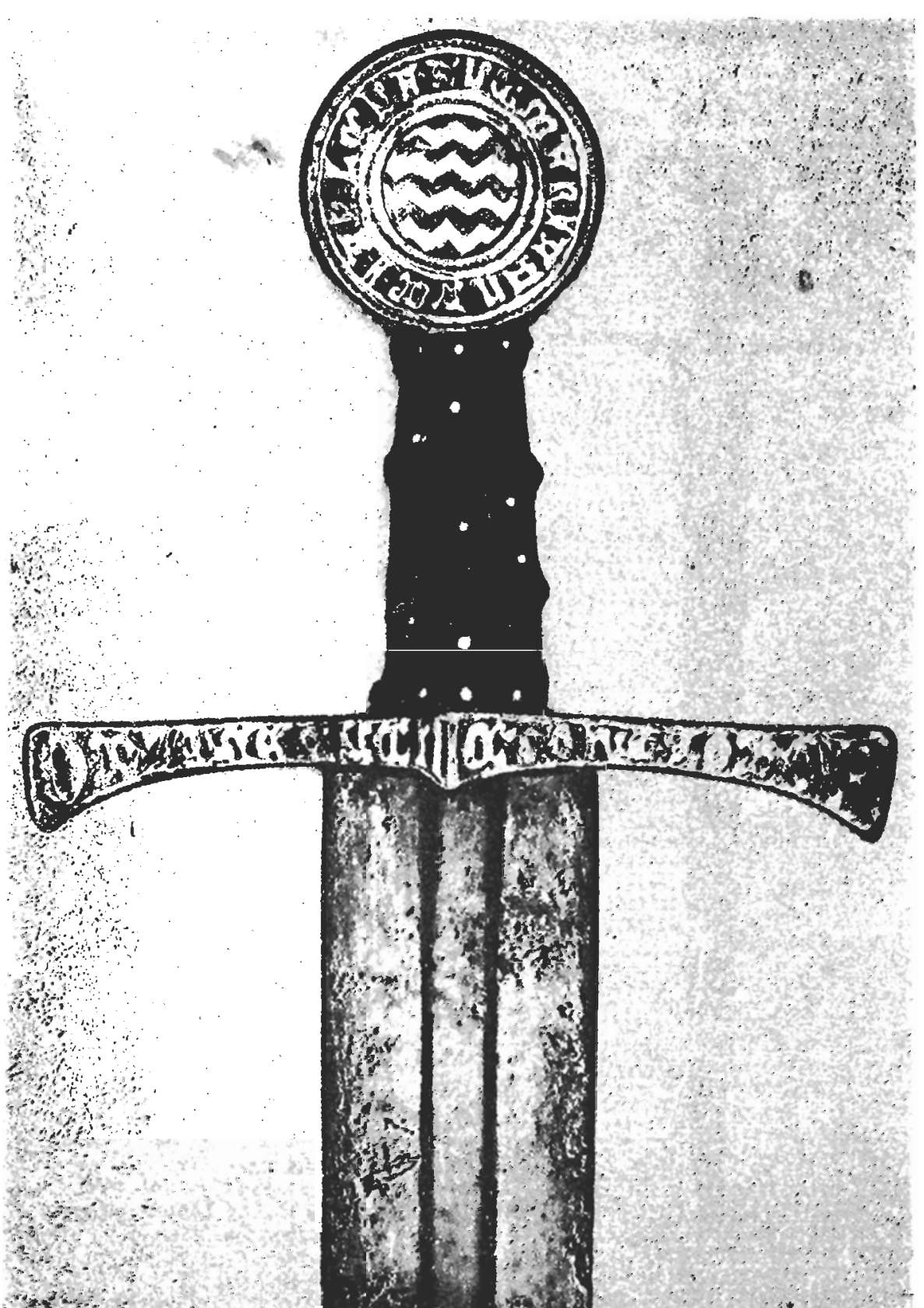

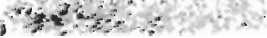

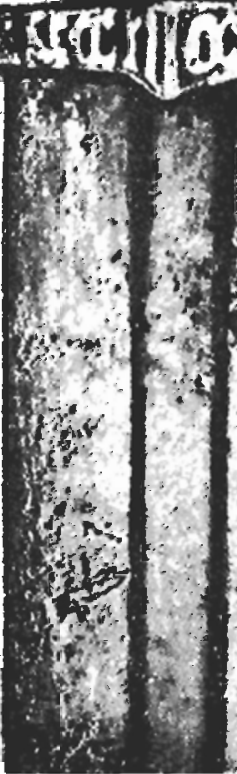

Whing

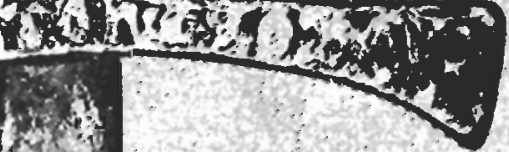

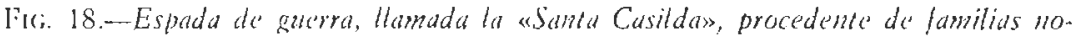
bles de la provincia de Logroño, ca. 1290-1300. Instiluto de Valencin de Don Jan, Madrid. Inscripciones en pomo y gavilanes. 
Gladius, Vol. especial (1988), pp. 31-101 Actas del I Simposio Nacional ISSN 0435-029X

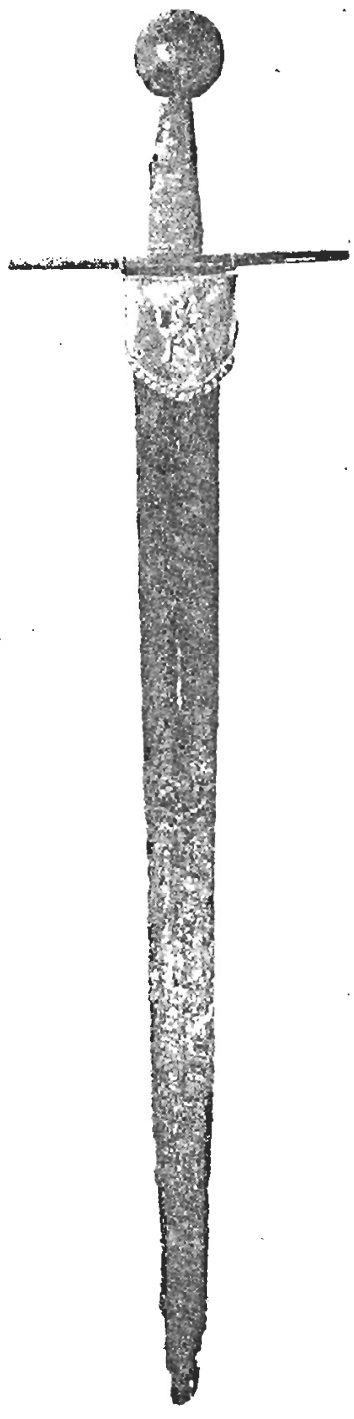

Fig. 19.-Espada llamada de "San Martin», antes de 1300. La guarnición de la vaina, de plata, con San Martín y el mendigo, más el escudo de Barcelona, son del siglo XIV. Hoy en el Musée de l'Armée en París, ex col. Georges Paullbac, Paris; ex col. José Estruch y Cumella, Barcelona. 
poder se había conservado desde el siglo xv. Ha pertenecido al rey Martín el Humano, de Aragón, pero se menciona ya en el inventario de Pedro el Ceremonioso, en 1370. Es posible que esta espada sea obra catalana, y más en concreto, barcelonesa. La vaina no es de la época, pero es del siglo Xiv. Está forrada con seda verde y tiene guarnición de plata dorada, con una representación de San Martín y el mendigo a su lado; al otro, el escudo de Barcelona. Según algunas fuentes de la época, ha sido la espada utilizada en la coronación de Martín el Humano, en la catedral de Zaragoza, en 1399. Pero este detalle no está suficientemente comprobado. Sufrió mucho daño durante la última guerra mundial en su depósito secreto en el sur de Francia; su punta está comida por la erosión.

\section{Las armas ofensivas de Alfonso el Sabio SEGÚN «LAS CANTIGAS»}

Con las espadas y espuelas históricas terminan las armas arqueológicas del siglo Xill. Para poder estudiar y conocer mejor el armamento en gencral y la espada cn particular durante cl siglo de la Reconquista y dc Alfonso el Sabio y sus hijos tendremos que buscar en el arte el material. Tenemos una excepcional fuente en las ilustraciones de Las Cantigas del. Rey Alfonso el Sabio, en El Escorial (ms. T-I-1). Como fuente de documentación, no sólo respecto a los cristianos, sino también a los musulmanes — sean de Andalucía o de los llamados sarracenos-, es un documento inestimable e indispensable en grado sumo. Aquí encontraremos todo el armamento utilizado en luchas y batallas, en los sitios a los castillos y a las ciudades y en los campamentos; también ballestas e ingenios de guerra en forma de trabuquete. Como la documentación es exacta y minuciosa a un nivel muy alto, a la par con las más destacadas ilustraciones del siglo Xı11, como las famosas de la Biblia Maciejowsky, en Pierpont-Morgan Library, en Nueva York, o Mateo de París, en Londres, ambas de 1250 aproximadamente, además de algunos otros manuscritos europeos de alta calidad, resulta una fuente inagotable para la investigación del armamento de la Reconquista. Toda clase de armamento de la época 一ofensivo y defensivo-- está representada en dicha documentación, hecha con todo lujo de detalles. Es muy importante para mostrarnos el armamento ecuestre. Son interesantes las muestras de la ballesta, bien la pequeña, para un pie; bien la grande, para dos. Es una de las armas más importantes, especialmente en este siglo, en España y en todas naciones europeas y musulmanas de las Cruzadas en Tierra Santa. 


\section{Las espadas}

En Las Cantigas son las espadas las que prevalecen entre todas las armas ofensivas. Existen de varios tipos: para la guerra, para ceremonias, también probablemente para lucirlas en la Corte. La diferencia existente entre las espadas moras y las castellanas no es muy grande. En ocasiones apenas si hay diferencia. Las ilustraciones nos muestran dos tipos de guerreros musulmanes: los hispano-moriscos, de Andalucía, y los «sarracenos» o almohades berberiscos, de Marruecos. Estos últimos, lógicamente, van equipados y armados a estilo árabe. En total aparecen ocho tipos de espadas, parte moras, parte castellanas. También pueden verse espadas curvas, en forma de bracamartes o falchiones, grandes y pequeñas. La tropa solamente es equipada con una espada corta y delgada, semejante más a una daga larga. No sólo las espadas cortas son características para la infantería en Las Cantigas; también los ballesteros, en el ejército de Jaime el Conquistador, en las pinturas murales del Salón del Tinell, en Barcelona, llevan pequeñas espadas con punta aguda (Fig. 24).

En dagas conocemos la existencia de varios tipos, pero su uso aún no es corriente en el equipo militar. La precursora de esta arma, característica entre los hispano-moriscos y posteriormente para casi toda la Península, especialmente Cataluña y Valencia, es la daga morisca o daga de orejas, con decoraciones imitando piedras preciosas; estas dagas las podemos ver un par de veces en Las Cantigas. Las orejas no son muy desarrolladas, pero el tipo es evidente. La daga «basilarde» está representada varias veces (Fig. 26).

Las armas de asta las encontramos en varias ilustraciones, pero siempre con menos frecuencia que las espadas. Las lanzas se representan con diversos tipos de hierros: largos, con un nervio vertical en el centro; en forma de hojas de olivo y en forma romboidal (Fig. 20). De cuando en cuando nos es posible ver también una de forma oriental, estrecha, prismática, de estilo persa. Las lanzas de los moros, y especialmente de los sarracenos, son características (Fig. 21). Un tipo de ellas es de hierros largos y dos o tres bolitas o aletas al pie del hierro y en el tubo. Otro tipo es el delgado, prismático, en estilo persa. Además existe un tipo parecido al partisano. Las diferencias entre los tipos cristianos y moros tienen su origen en la diferencia de su arte ecuestre. Las lanzas grandes son para la caballería pesada de los cristianos, con sus regatones largos y fuertes (como se conocen, desde la época visigoda, por los ejemplares arqueológícos conservados, por ejemplo, en el Museu Provincial de Pamplona). Los tipos orientales los utiliza la caballería ligera de los moros y sarracenos; estos tipos también tienen sus regatones. Las pequeñas rodelas, utilizadas para proteger las manos en el asta de la lanza, no son utilizadas 


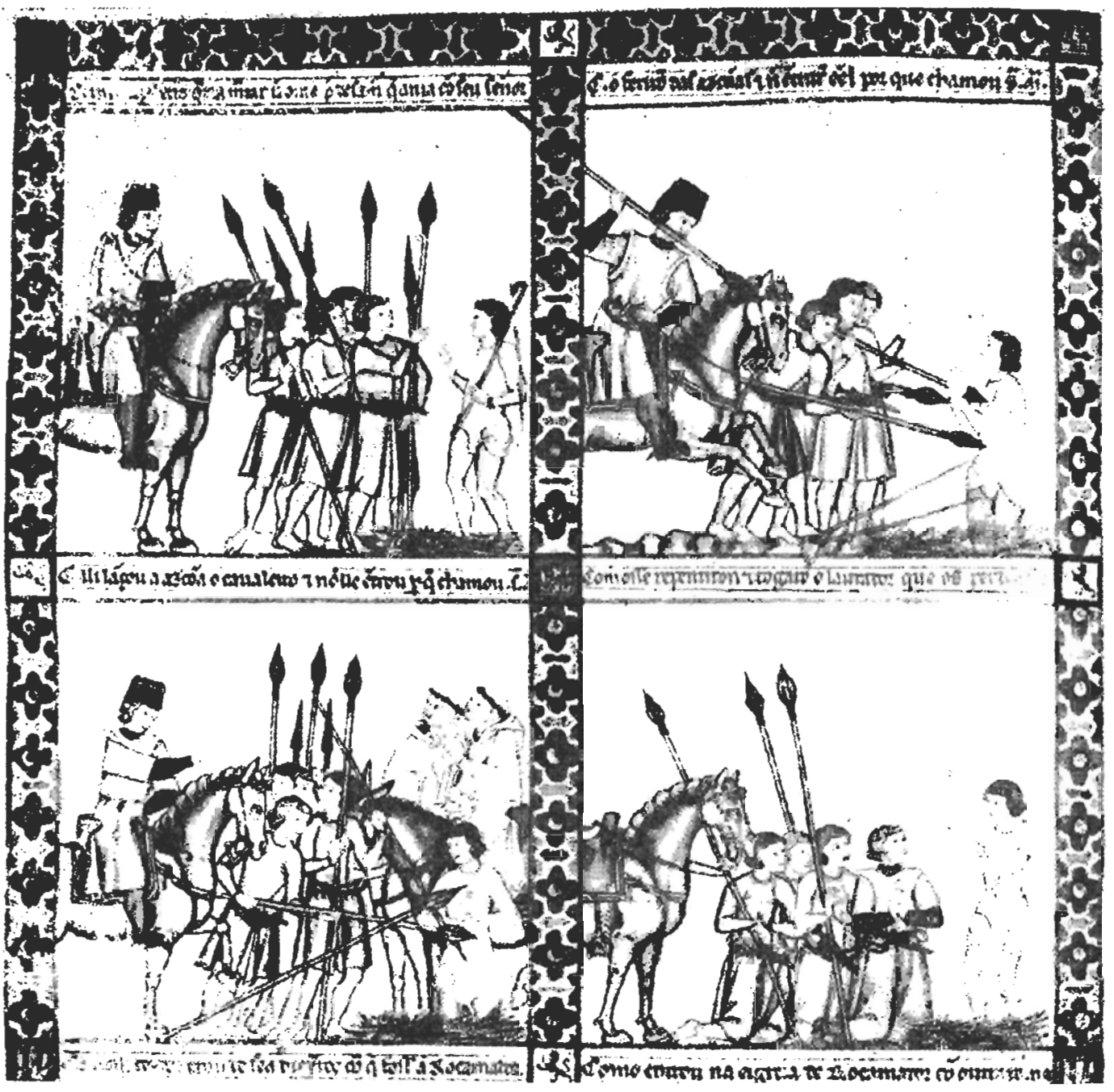

F1G. 20.-Cant. XX11, "Las Cantigas». Buenos ejemplos de lanzas y sillas de la épaca. 


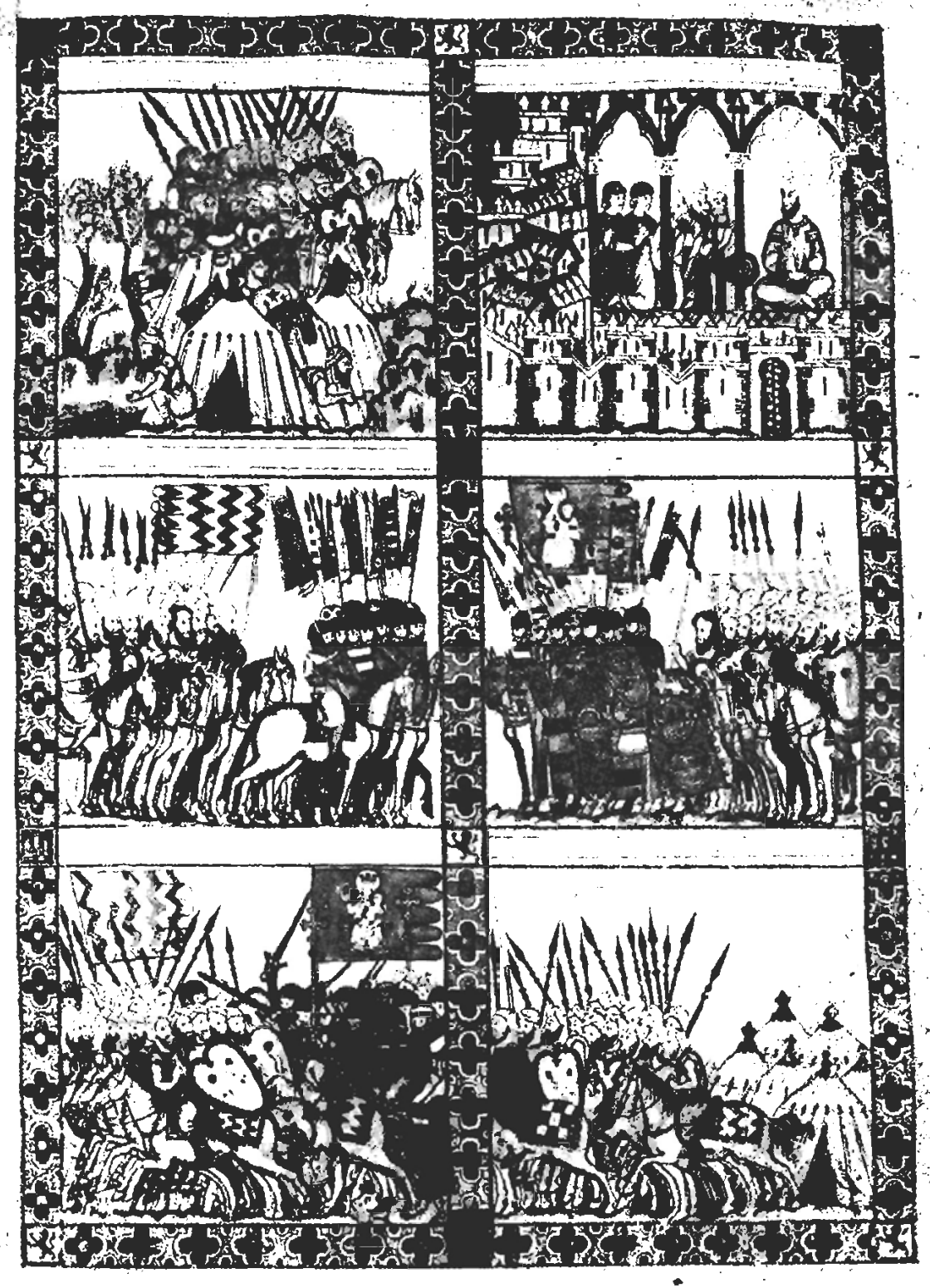

Fig. 21.-Canl. ClXXXl (cancrón stn icx/o). Lanzas y adargas moras. 


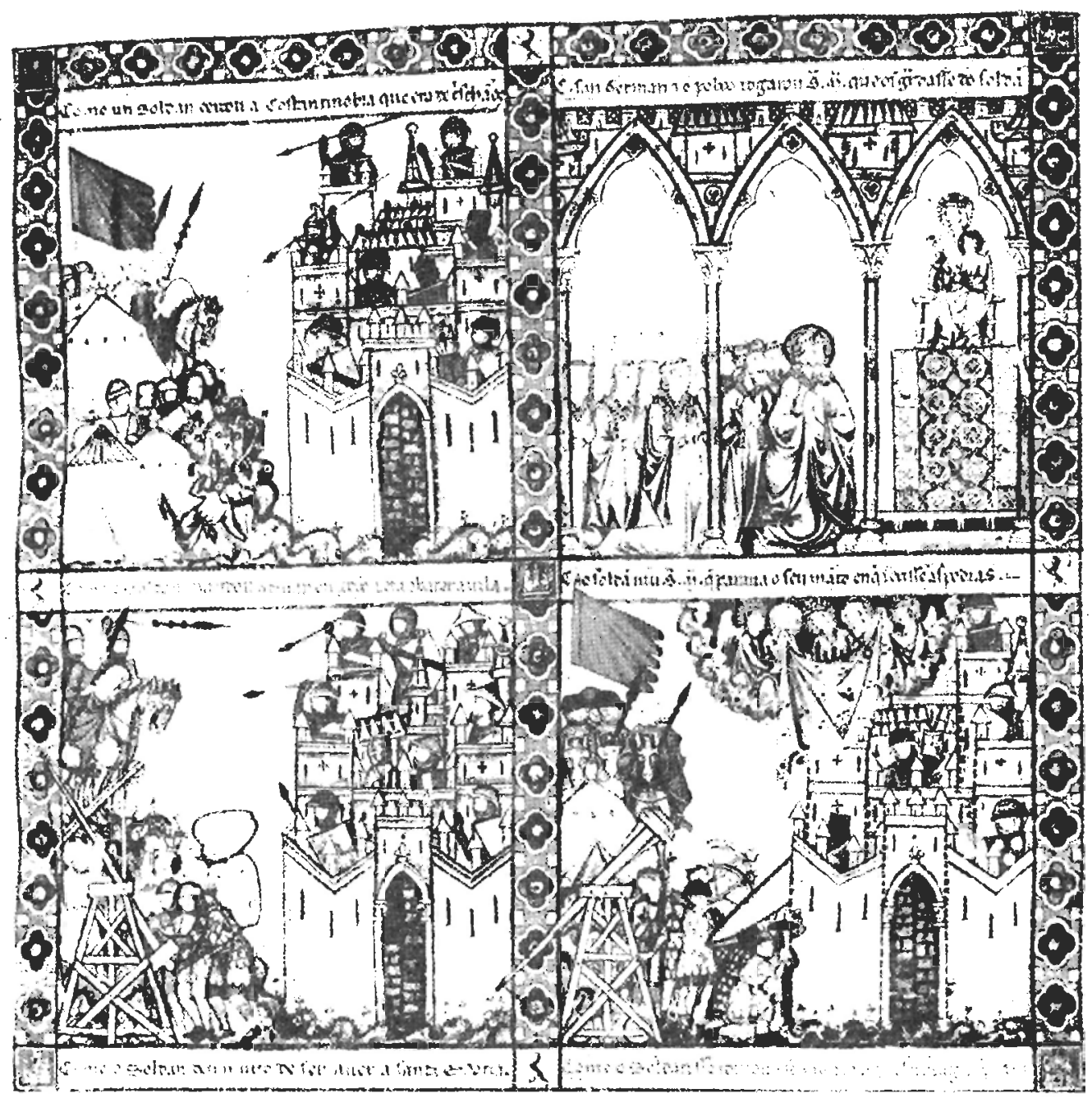

FIG. 22.-Cant. XXVIII. Sitio del sultán a Constanlinopla. Lanzas moras, jabalinas arrojadizas cristianas. Ballestas y trabuquete con contrapeso fijo. 
todavía en este tiempo. La infantería tiene como armas arrojadizas jabalinas, dardos y venablos ligeros (Fig. 22). El arte en estas armas no tiene la misma importancia o interés que el de las espadas.

\section{Arcos y ballesias}

El arco con su flecha no tuvo gran importancia en la Península, excepto en Andalucía. Su uso es más frecuente entre los musulmanes (arcos turco y árabe) (Fig. 25a-b). El arco de los ingleses, introducido en la Península en el siglo xiv por el Príncipe Negro, Eduardo de Gales, hijo mayor del rey Eduardo III, fue usado en las batallas de Nájera y de Aljubarrota, pero nunca tuvo excesiva importancia en este país.

En Las Cantigas, el arco turco o árabe está representado algunas veces. En esta época, los sarracenos gozaron de gran fama no sólo en el mundo mediterráneo, sino también en muchas partes de Europa como competentes constructores de ballestas y arcos, de ahí que trabajaran en las cortes europeas para reyes y príncipes. En la Península, el centro más importante sin duda era Córdoba, con su gran producción de arcos y ballestas (según fuentes árabes); pero también Barcelona y las Baleares tenían importancia, así como Zaragoza y Vizcaya, que gozaban de cierta fama. La ballesta es muy importante en el arte y en la literatura, no sólo en el siglo xilı, sino incluso en el xiv (Fig. 23a-b). Fue una de las armas más terribles en los encuentros hostiles entre cristianos y sarracenos en Tierra Santa. Los Papas, en dos concilios, prohibieron su uso, pero resultó vano su intento. Su papel en la Reconquista, en el siglo xiıI, así como en la toma y rendición de Granada, en 1492, fue bastante grande; la usaron tanto los cristianos como los musulmanes. La ballesta de la infantería (Fig. 24), y en cierto modo también de los guerreros montados, contribuyó, probablemente más que las lanzas fuertes de choque, en el desarrollo de la armadura reforzada y pesada para hombre y para caballo. Es en este siglo cuando la protección del caballo con cobertura de malla de hierro («loriga de caballo»), o de cuero bollido, con su testera, o de hierro forjado, con cintas de otro metal o de cuero bollido, se extiende por España y en el Occidente (Fig. 26). La cobertura de cuero crudo es también de este siglo. Las coberturas son bastante largas para poder proteger de las saetas las patas del caballo. En el siglo XIv - y probablemente más en Cataluña que en Castilla_-, coberturas plegadas hechas con telas fuertes pueden observarse en las ilustraciones y relieves.

Según la Primera Crónica General, los mejores constructores de esta arma, así como los más expertos ballesteros del mundo de entonces, se encontraban en las Baleares. Es cierto que entre los ballesteros mercenarios en el Occidente, los españoles tenían casi igual fama que los de Gé- 


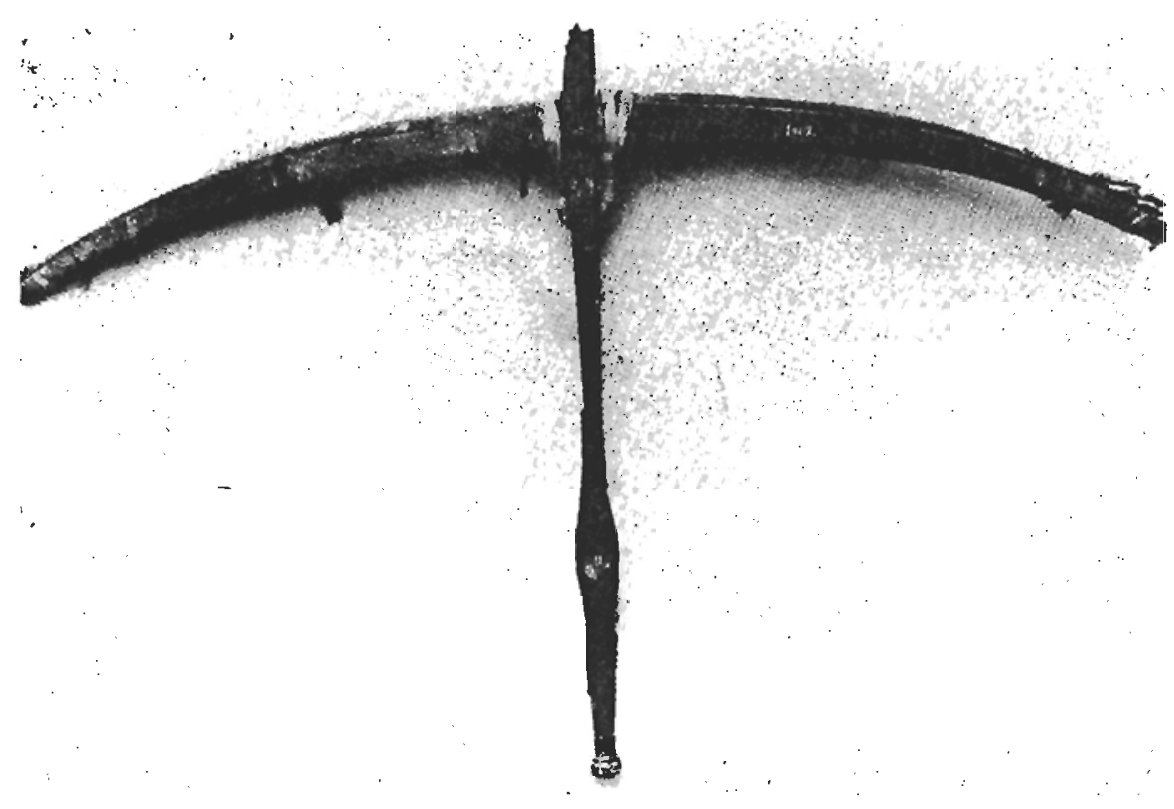

FIg. 23a-b.-a: Bullesta compuesta, de Granada. Arco de madera con pergarnino antiguo. Cureña de la época nazarí de madera con inlarsia de bueso pintado, $y$ de bronce, en estilo de los comienzos del siglo XIV. b: Ballesta de Cant. CXXVI; "Los moros Jucra do Elche". Ballesia de dos pies, con gancho para la tensión.

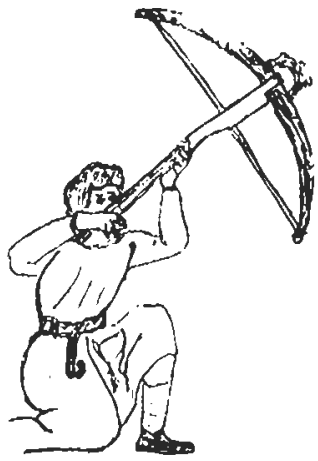

nova. Jaime el Conquistador fundó en Valencia una compañía de ballesteros. El arma la utilizó mucho Don Jaime y sus guerreros en el sitio de Valencia, y el rey mismo tuvo la desgracia de ser gravemente herido en su frente por un virote de ballesta, herida que más adelante le produjo la muerte. Su calavera, en su tumba en el Monasterio de Poblet, es testigo de esta lesión. 
Alfonso el Sabio, en Las Siele Parlidas, menciona la ballesta con sus variados tipos y tamaños: de estribera pequeña, para un pie; de estribera grande, para dos, que necesita de un gancho especial en el cinturón del guerrero para conseguir tensarla (Fig. 23b), y la más grande, ballesta a torno, probablemente colocada encima de una cureña o carro y usada para lugares fuera de los muros o a bordo de naves de guerra. La compañía de ballesteros, representada en las pinturas murales del Salón del Tinell, en Palau Mayor (Barcelona) (Fig. 24), del ejército de Jaime el Conquistador, solamente tiene pequeñas ballestas. En Las Cantigas leemos sobre infantería con ballesta de un pie y guerreros tensando ballestas, con el gancho sujeto en el cinturón con una pequeña correa especial, más las grandes para dos pies utilizadas en los sitios. Particular interés tiene la ballestal grande en Cant. CXXVI, con el caballero que fue herido por una saeta en su ojo que los moros de Elche echaron. Se aprecia cómo sus companeros tienen la intención de sacarle la saeta de su ojo, que se le clavó por disparar la ballesta en dirección contraria. Otro ejemplo es la ballesta muy grande en Cant. CLIV, representando el «Tafur», la Virgen y la sangre. Conocemos las ballestas andaluzas o nazaríes gracias a las descripciones que hace Ibn Hưail en su obra Gala de Caballeros, Blasón de Paladinos del siglo XIV, una obra que, sin duda, tiene sus raíces en obras árabes similares del siglo XuI.

La ballesta fue sumamente apreciada por los nazaríes de la Alhambra para la guerra, la caza y deportes. Ibn Hudail describe los tipos y clases de madera más apta para su construcción, de cuerna de ciervo, así como de la fabricación y la ornamentación, etc. Las ballestas de lujo, entre los príncipes nazaríes, eran — según la descripción- ricamente decoradas con incrustaciones de nácar, hueso o márfil, así como con aplicaciones de metal, por ejemplo, de bronce, como se ve en el ejemplar conservado en el Museo Provincial de Granada, en Casa de Castril (Fig. 23a). Las ballestas representadas en las bien restauradas pinturas murales de la Torre de las Damas, en el Partal de Alhambra, se corresponden con los tipos que muestran en Las Cantigas.

En conexión con la ballesta medieval, en España se debe mencionar la importantísima obra de Alonso Martínez de Espinar: Arte de Ballesleria y Monteria, publicado en Madrid en 1644. El autor, que era montero y ayuda de cámara de los reyes Felipe III, Felipe IV de Austria y el príncipe Baltasar Carlos, se lamenta en su libro de que en aquella época se hubiese perdido el gran arte de construir ballestas, no obstante ser España, en tiempos anteriores, el país con los mejores maestros en ballestería y con el mayor conocimiento en el arte de su construcción. 


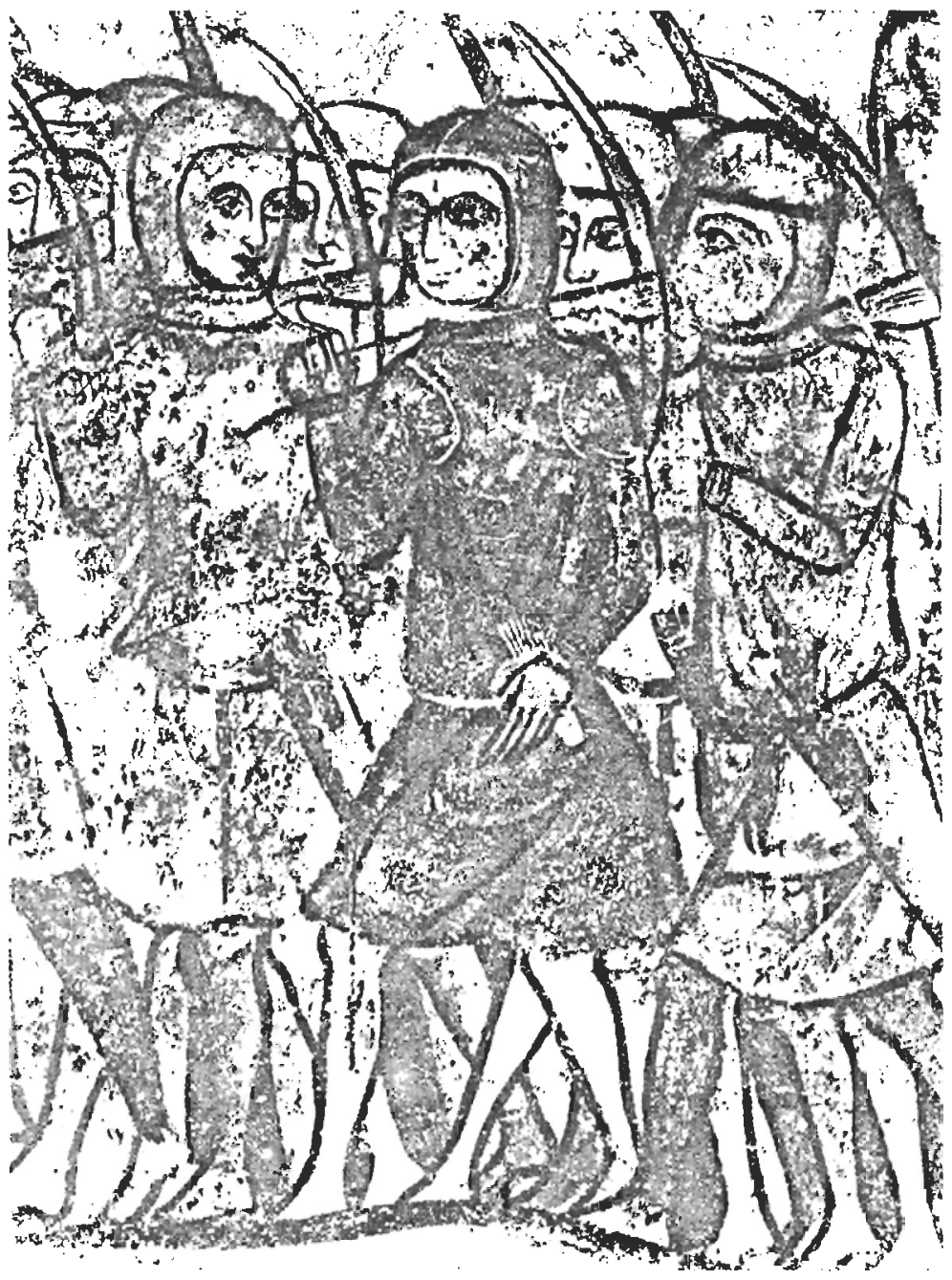

Fig. 24.-Compañia de ballesteros de Jaime el Conquistador. Pintura mural. Salón del Tinell, Barcelona. 


\section{La artillería}

A Alfonso el Sabio también le interesaba la artillería. Esto debe ser mencionado en relación con la ballesta. No sólo fue el Rey Sabio quien tuvo artillería; también Don Jaime el Conquistador utilizaba estas máquinas o ingenios de guerra en los sitios que ponía a las ciudades durante la Reconquista (Fig. 22); así nos lo demuestra la literatura de Cataluña en muchísimas fuentes de la época. En este siglo se usaban las ballestas grandes, de dos pies y a torno, más otras de diversos tamaños: de algarradas, manganas y trabuquetes. Son rarísimas las reproducciones de estos ingenios. No obstante, Las Cantigas nos muestran con toda claridad un excelente ejemplar de un trabuquete (Fig. 22). En el asedio de Constantinopla por el sultán musulmán, los sarracenos fuera de la capital bizantina tienen grupos de ballesteros con ballestas de dos pies. Estas están combinadas con un trabuquete con contrapeso fijo, que fue la segunda etapa en el desarrollo de este tipo de armamento. Los artilleros están protegidos por grandes paveses especiales, y los pioneros, con hachas, están picando los muros de la capital. Los ingenieros construyeron el trabuquete con objeto de poder lanzar piedras, sacos pesados, etc., u objetos incendiarios dentro de los muros. En este caso, los proyectiles son piedras, porque se puede apreciar cómo la Virgen, para proteger a sus fieles dentro del sitio, con su manto grande recoge las piedras lanzadas contra la catedral. En estas ilustraciones vemos exactamente el trabuquete. Es una de las muy raras representaciones que existen de este tipo de ingenios (Fig. 22). Es la «moderna» máquina de guerra una invención de los bispano-moros en Andalucía y probablemente también de los moros de Sicilia. Es una invención o mejora de la algarrada y de la mangana, que funcionaban por medio de cuerdas que manejaban los soldados. El nuevo tipo de Alfonso el Sabio funciona con contrapeso fijo. Parece que España, en esa época, tue uno de los países más avanzados en Europa en lo que respecta a este tipo de máquinas de guerra. En toda la Península se ha construido y usado de este material para lanzar piedras u otros objetos pesados, además de muchas otras cosas rarísimas, dentro de los muros de castillos y ciudades. Conocemos bastante bien este tipo de artillería por la literatura de la época. Existe una extraordinaria variación en la terminología. Poseemos muy variados tipos y muchísimos nombres, especialmente en los textos de Gran Conquista de Ultrumar y más aún en la literatura catalana. Interesantes son las descripciones en Las Siete Partidas, II, 23, 24 y 24, 9, donde don Alfonso habla con claridad de los dos tipos de la época: los que tiran piedras por contrapeso fijo y los que lo hacen por cuerdas. Las últimas son las más antiguas, y reciben el nombre de algurrada, nombre árabe y siríaco, originalmente significa «borrico 
salvaje». Los romanos llamaban a sus máquinas lanzapiedras con un brazo solo onagro o borrico salvaje, pero éstas funcionaban por cuerdas de torsión y no por palanca, como las máquinas de la época medieval. Las de tipo algarrada también las había en tamaño mayor, Ilamado mangana, mangona, manganilla, manganiq, etc., nombres de origen griego (y árabe) bien conocidos en la literatura bizantina. Estos tipos proceden de Bizancio, Irán y Yemen. El trabuquete — como éste de Alfonso el Sabio- es el invento del mundo islámico occidental (Andalucía y Sicilia). También fue usado en Ifriquia. Con su contrapeso fijo, es la máquina más caracterizada del siglo xilı. En este siglo tuvo gran importancia en los sitios de Tierra Santa durante las Cruzadas. Para su construcción en esta época ya no existía madera en Palestina o Siria. Los ingenieros tuvieron que buscar su material en Sicilia y España. Alfonso el Sabio prohibió la exportación de madera de España a los sarracenos para la construcción de máquinas de guerra. También esto está expresamente mencionado en Las Siete Partidas.

El sistema de palanca, a pesar de funcionar más o menos como una honda, era, respecto a sus proporciones, bien calculado. La parte corta, con fuerza de impulsión, medía casi un quinto de toda la palanca, bicn sca del tipo con cuerda, de la que tiraba un grupo de soldados, bien sea por una caja fija llena de piedras, sacos de arena, plomo u otras cosas diversas más o menos pesadas. La parte larga, con los ganchos para el saquito del proyectil, disminuyó en grosor, pero mantenía las proporciones exactas y muy bien calculadas hasta los ganchos. Un algarrada más grande que el tipo corriente, la llamada manganilla, mangona o mangana, también perteneció a la artillería de Alfonso el Sabio y a Jaime el Conquistador. En fuentes literarias de esta época, los ingenios bélicos son frecuentemente mencionados en Cataluña y Valencia por su presencia y función en los asedios de Mallorca y Valencia por Jaime el Conquistador.

En el Imperio bizantino, en estos siglos, las fuentes griegas las llaman manganiques, manganel, petreros. Están representados en varios manuscritos, entre otros en el Manuscrito bizantino de Scylitzes, en la Biblioteca Nacional, en Madrid, de la misma época. El tipo más avanzado, con contrapeso móvil, no está representado en los manuscritos peninsulares. No obstante, es bien conocido de un manuscrito mongol de ca. 1306-09, de la bistoria mundial de Rashid-el-Din, hoy en la Biblioteca Nacional de Edimburgo, representando una escena de asedio de una ciudad en Asia, todo muy semejante a la escena de Las Cantigas. El siglo xiv nos muestra un tipo aún más avanzado, con dos contrapesos, uno fijo y otro móvil, y con sus cuerdas y maquinaria para ponerla en funcionamiento. Aegidius Romano Colonna, hacia 1275 , en su libro De Regimine Principum, menciona todos estos tipos. El último y el más complicado es el que llama 
tripantium. Todavía en el siglo xv se usaban estas máquinas al lado de la artillería con pólvora, ya que eran más efectivas que la nueva artillería en sus diversas formas, llamadas bombardas o lombardas, etc.

\section{Las armas defensivas de Alfonso el Sabio SEGÚN «Las Cantigas»}

Las Cantigas nos ofrecen una excelente exposición de las armas defensivas del siglo xilr. Toda clase de éstas están representadas fielmente y con mucho detalle. Las lorigas largas con mangas largas, los lorigones cortos y hasta los lorigones, casi coseletes de escamas, pertenecen a las mejores representaciones que existen de este tipo de armamento. La combinación de loriga larga con lorigón de escamas es característica para los artilleros, ballesteros e ingenieros en Las Cantigas (Fig. 22). Tanıbién İas clos ilustraciones de la Gran Conquisla de Ullramar, de la misma época, en la Biblioteca Nacional, en Madrid, nos muestran esta combinación, en realidad la precursora de las cuirasses (corazas) del siglo xiv (Fig. 25a-b). Importantísimas son también las representaciones de los ejércitos de Jaime el Conquistador, en el Salón del Tinell, en Barcelona, de la misma época, ejércitos que contaban con caballería, infantería y ballesteros, no sólo catalanes y aragoneses, sino también de los moros de las Baleares, del reino moro de Mallorca. Aunque en lo principal el armamento es casi igual en Castilla que en Cataluña-Aragón, existen diferencias notables respecto a detalles, quizá porque Cataluña-Aragón tiene un contacto más íntimo con el sur de Francia y con Italia del Norte (Lombardía y Toscana) gracias a sus vías marítimas por todo el área mediterránea en esta época. Debajo de su loriga, el guerrero se pone una camisa suave y su gambax acolchado, con algodón por dentro. Suele ser de material fino, como, por ejemplo, seda, pero lo corriente es que sea una tela fuerte, incluso gruesa, según la categoría social y la economía del guerrero. El gambax no es exactamente un vestido militar; también lo usan los civiles. Los soldados pobres normalmente no tienen otra clase de protección. Encima de la loriga de malla el caballero se pone su surcoal, su perpunte, de seda o de algún tipo de tela fuerte, pero bonita. Este también puede ser acolchado. Originalmente, el perpunte no tenía ornamentación ninguna, pero pronto se comienza a decorar el vestido con figuras más o menos heráldicas. Los perpuntes erill conocidos ya al final del siglo xiı. Fueron utilizados por los cruzados en Palestina, probablemente como protección contra el sol o la lluvia, como nos dice Ramón Llull en Libre de l'Ordre de cavalleria; éstos se desarrollan calda vez más durante el siglo xili. Sus formas se nodifican, desde las túnicas largas, con muchos pliegues, hasta tipos más 
cortos y cómodos, con y sin mangas. Sus bordados con hilo de seda, oro o plata, de origen decorativo, pronto se convierten en figuras y símbolos heráldicos. La loriga y el lorigón son construidos normalmente por anillos de acero o hierro, y algunas veces acaban en una orla de anillos de cobre o latón de carácter decorativo. Existen varias formas y maneras respecto a su construcción: anillos de placas finas redondas perforadas en el centro, puestas sobre un fondo de cuero o tela fuerte, en realidad una herencia de la época romana tardía. Hay unos pocos ejemplos de este tipo en Las Cantigas. Algunos anillos son de hilo de acero o hierro, entrelazados, remachados y cerrados con pequeños clavos. La manera de su construcción puede ser diferente entre Occidente y Oriente. Esto es comprobable en los pocos hallazgos arqueológicos de cotas de malla medievales y posteriores. Con placas redondas se construyó la loriga que trae Vilardell en el relieve de la puerta esculpida de la catedral de Barcelona, de esta época. El tipo se ve un par de veces en Las Cantigas. También éstas nos muestran excelentes ejemplos de lorigones de escamas en forma de tejas o plumas. Así visten los artilleros y ballesteros en el sitio de Constantinopla según Las Canligas (Fig. 22), Cant. XXVIII. El mismo tipo se aprecia en las dos ilustraciones de la Gran Conquista de Ultramar, en la $\mathrm{Bi}$ blioteca Nacional (Fig. 25a-b).

Los caballos en Las Cantigas están protegidos con grandes coberturas de malla y nos muestran uno de los más tempranos y completos ejemplos de esta protección de los caballos (Fig. 26). Asimismo, este tipo de protección es conocido también en Inglaterra. En España son frecuentes en la época de la Reconquista; también en Catalıña, pero menos usuales que en Castilla. Ejemplos excelentes de ello podemos verlos en la iglesia de San Francisco, en Palma de Mallorca, en el retablo de Santa Ursula. Otro se encuentra en Navarra. La diferencia entre estos ejemplos y los de Las Cantigas estriba en que en éstas los caballos tienen testeras de hierro reforzadas con cintas decorativas de otro metal, mientras los de Mallorca son de cuero bollido con ornamentación pintada. Otro ejemplo de Cataluña se encuentra en la pintura mural de la Casa de Berenguer d'Aguilar, del Carrer Montcada, hoy en el Museo de Arte de Barcelona, que representa a Guillem de Monicada, de finales del siglo xiII (Fig. 29). La protección ecuestre en Cataluña suele ser de tela, de cuero crudo o cuero bollido, y la testera, de este mismo material. Así se ve en algunos sellos reales de este siglo. A fin de no dañar a los caballos, las lorigas de malla iban forradas en su interior con alguna clase de tela. Las coberturas de tela eran ricamente ornamentadas, con decoración heráldica en gropera y trasera, que se correspondía con la que llevaban los caballeros en sus escudos. La protección del caballo con testera de hierro, listones decorativos, rejillas para ojos, tubos para orejas y combinado con la loriga de 


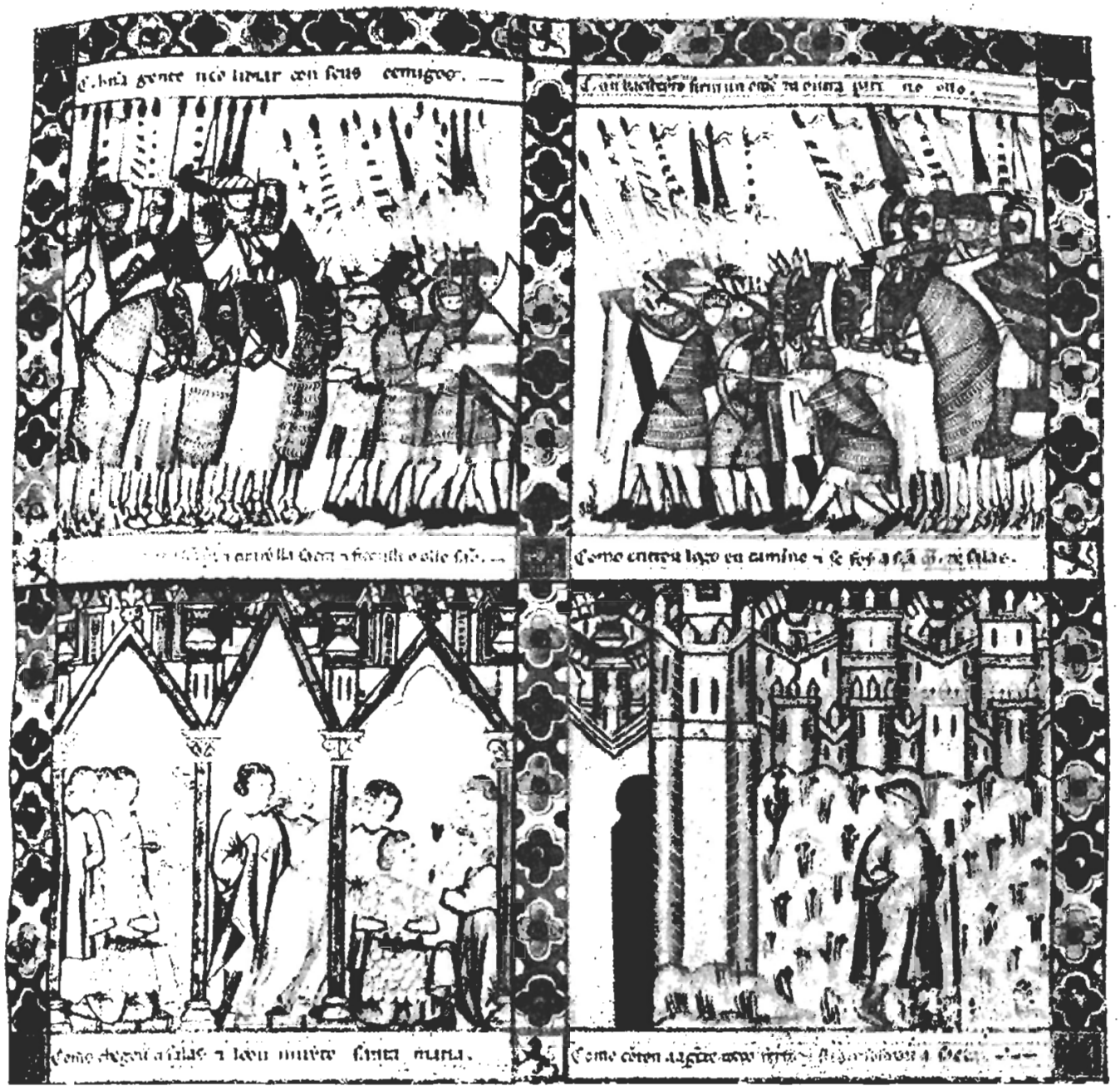

Fig. 26.-Armas delensivas en «Las Canligas». Cant. CXXIX. Lorigas de malla, con mangas largas, almófor, "capiellos de fierro», capellinas, yelmos de forma de tonel, halléstero con lorigón, con mangas corlas. Inlante en lorigón de escamas; está berido en el njo, pero curado por la Virgen. Caballos con loriga de malla, con testeras de melal, con prolección para ojos y orejas. El infante en lorigón de escamas tiene daga de tipo «basilarde». 
malla es el característico en Las Canligas y algunas otras obras castellanas; tiene pocos paralelos fuera de Castilla, en tanto que, para este período, el equipo de Cataluña-Aragón es parecido al de Francia y Alemania.

A mediados del siglo xir notamos por las ilustraciones un cambio, $o$, mejor dicho, solamente una tendencia a ese cambio en lo que respecta a las armas defensivas. Esto se debe, entre otras cosas, a las duras batallas en Tierra Santa en la época de San Luis. Las armas ofensivas, particularmente las ballestas y las lanzas grandes y pesadas, más los arcos turcos de la caballería ligera de los turcos y sarracenos, se convierten en las más peligrosas de la época. Comienzan con un reforzamiento de las lorigas, con piezas o láminas rígidas, de hierro, y grandes o pequeñas placas de metal, según el fin del traje de guerra. Los primeros tipos de protección en forma de cuirusses comienzan a aparecer en la segunda mitad o quizá en la última cuarta parte del siglo. Las cuirasses solamente son, en principio, una clase de perpuntes de cuero reforzados con placas de metal embutidas en el cuero o canvas. Las Siete Partidas las Ilaman «fojas». Constan de dos partes: frente o peto y dorso, cada una de ellas con sus placas fijadas y embutidas en una capa de canvas, algodón, etc., por dentro y por fuera forradas con cuero o terciopelo, en donde se aprecian los clavos, frecuentemente de bronce o de cobre dorados. Hay varios sistemas para cerrarlos: al dorso, por el lateral y al frente. La forma de brigantina hecha en este estilo, pero de láminas pequeñas, va a ser una de las protecciones más frecuentes e importantes de los siglos xiv y xv. Se fabricaban, entre otros lugares, en Valencia, exportándose a Italia (Lombardía), aunque también se fabricaban en Milán para la exportación. Este traje, todavía llamado «armadura blanda», a finales del siglo xv y comienzos del xvI, va a ser la armadura de los ballesteros españoles, en combinación con el típico capacete estilo de Calatayud. Las placas grandes conducen, a finales del siglo XIv y comienzos del Xv, a la armadura «blanca», la armadura completamente hecha por placas de hierro o acero rígido, protección característica desde la segunda mitad del siglo xv. En la última parte del siglo xir se empiezan a proteger mejor y más completamente los brazos y piernas con un material más flexible debido a sus láminas, en forma de listones de metal rígido con articulación, con rodelas especiales para axilas, codos, muslos, rodillas, etc., y con sabatones articulados de metal o de escamas de metal, ballena o cuero bollido.

La prolección de la cabeza es muy característica en este período. Aparte de las capuchas de malla, los almófares, en combinación con la loriga y las ya mencionadas formas de cascos de cabeza de hierro, frecuentemente martilladas en un solo trozo de metal, existe en este siglo un tipo muy especial. Es el tipo más característico en Las Cantigas, y se usó especialmente en las campañas de las últimas Cruzadas en Tierra Santa: es el yel- 
mo en forma de tonel. Es una caja cilíndrica, compuesta de cuatro o, más frecuentemente, de cinco placas de hierro, reunidas con clavos de hierro, bronce o latón, casi siempre dorados. Estas placas están reforzadas con cintas de metal, que se puede ver claramente en las ilustraciones. Este yelmo (topfhelm, beaume, belm) es la protección típica de los siglos XIII y primera parte del xiv. Es creación occidental. Ni los sarracenos ni los moros auténticos usaban una protección tan incómoda y tan pesada, con muy pocas excepciones, pero entonces eran de una forma especial que no tenía parecido con los utilizados por los cristianos.

Se utilizaba para resistir a las saetas de las ballestas, a los golpes de choque de las lanzas grandes y a las espadas largas tajantes. La gran época de este yelmo, para la guerra, es exactamente la de San Luis y Alfonso el Sabio. Esto se nota con toda claridad en Las Cantigas (Figs. 27 y 28). Para Jaime el Conquistador y la nobleza catalano-aragonesa no reviste la misma importancia que para los castellanos. En Europa existen varios modelos del siglo xilı, entre ellos un ejemplar bien conservado que se encontró en Pomerania, en Alemania del Este, de Dargen, hoy en el Museo Histórico Militar de Berlín del Este, aproximadamente de 1250. De Suiza existen dos de Madeln, otro en Küssnach, uno se ha encontrado en Bolzano, en Italia del Norte; otros dos son de Francia y uno de Suecia. El yelmo de Dargen está muy cerca de los yelmos que registran "Las Cantigas». Tiene la misma forma e iguales los listones aplicados, aunque no son decorativos como los de Las Cantigas. Es un yelmo para usar en combate. Al parecer no se conoce ni un ejemplar en España, jcosa bastante rara! Deben encontrarse ejemplares en alguna iglesia o capilla olvidada ¡todavía no registrada!

No se le localiza en las tumbas esculpidas del siglo xiv como en otros países de gran parte de Europa. En algunas catedrales de España, por ejemplo, en los tímpanos de las puertas, en los claustros esculpidos, etc., vemos de vez en vez guerreros y nobles haciendo torneos y equipados con yelmo de tonel; por ejemplo, en Toledo, Pamplona, Teruel y Tarragona. Estos últimos tienen parecido con el arte de Toscana y Lombardía. Es tentador llamar español al tipo de «Las Cantigas» por su falta de paralelos en otros países, ni en arte ni en realidad. Además es posible que sean de talleres de Zaragoza. En esta época, esta ciudad gozó de fama por sus yelmos, frecuentemente mencionados en la literatura de la época: «yelmo bueno, yelmo hermoso de Zaragoza». Crónicas catalanas y castellanas elogian los yelmos de Zaragoza. Son preciosos, ricamente adornados con aplicaciones de oro, plata, piedras preciosas, etc. Las fuentes dicen «que eran tan ricos en adornos y piedras, en oro y plata, que apenas se pudo comprarlos por dinero». Ejemplos de estos yelmos de tonel, adornados con piedras preciosas y ornamentos, existen en algunas ilustra- 


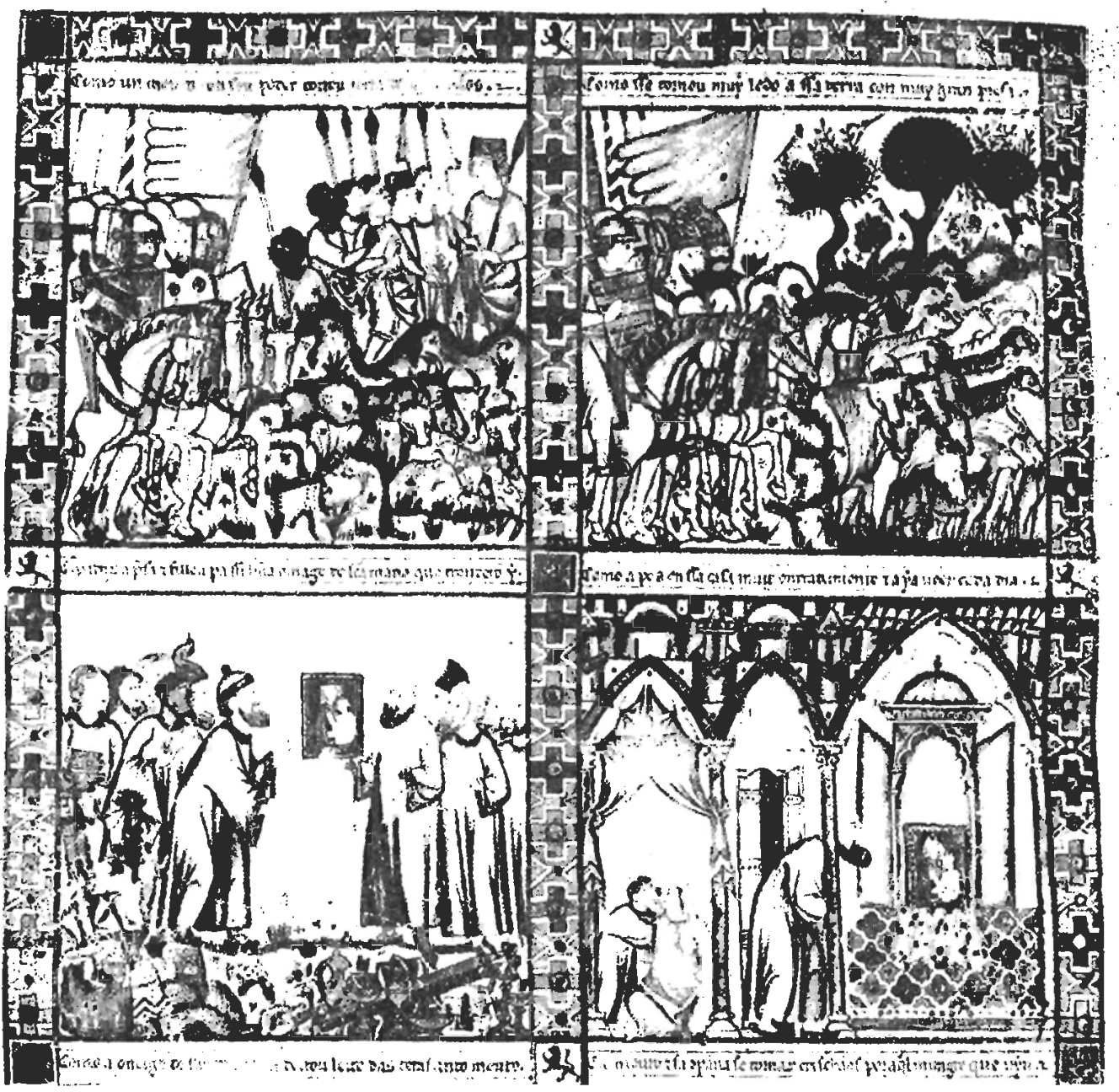

FIG. 27.-Cant. XLVI: Grupo de moros conquistando lerreno cristiano, algunos veslidos a mancra cristiana, olros con tuibantes y can yclmos lipo moro, con alto follais de acamlo e'n el ápex, más adarga de cuevo, los caballos sin cobertara y sin testera. Entre lor obichos de bosin bay aspadas del lipo. Real Armería (G 22) (Furnando d Sunto o Alfonso et Sabio) 
ciones de manuscritos, entre ellos en el de Mateo de Paris, en Londres; otra en el francés Brit. Mus. Roy. MS 2, XXXII, fol. 219, de finales del siglo Xi11. (Posteriormente, en el siglo XV, a Calatayud se le conoce como centro de importancia en la fabricación de capacetes y morriones. Más adelante, esta ciudad gozaba de fama internacional en el mundo, particularmente entre los lansquenetes de Maximilian I de Austria y otros reyes y príncipes de Europa, que compraban capacetes [«Spanische Helme», «Spanische Cabassets»] en los famosos talleres de Calatayud.) Los yelmos del tipo de tonel eran en Cataluña diferentes a los de Castilla, según se aprecia en las representaciones artísticas. Los yelmos de tonel de esta parte de la Península se asemejan más a los del norte de Italia. Los yelmos de tonel todavía no tenían ni lambrequín, ni mantelete, ni figuras de heráldica en su ápex (con la excepción del ejemplar del disco de cuero en Pamplona, que tiene como figura heráldica un pájaro). En Las Cantigas se nota algunas veces una pluma en estilo oriental o un muy pequeño pendón. Esto pudiera ser una reminiscencia de la época morisca de Zaragoza, con sus antiguas armerías moriscas.

En Las Cantigas, al lado del tonel corriente, se describe otra forma de tonel. Es un yelmo grande, no exactamente cilindrico, puntiagudo en el ápex, con un nasal ancho y superpuesto de hierro, dorado y terminando por encima en una gran flor de lis u hojas de acanto, en forma de cresta. Es un tipo de yelmo característico para los moros en este manuscrito y parece difícil encontrar paralelos en otros (Figs. 27-28).

Bajo el tonel, la cabeza está protegicla por el almófar, con una cofia de tela o cuero y una especie de corona de tela acolchada como soporte entre almófar y tonel. La corona de este tipo poco a poco desaparece. Va a ser sustituido por una cáscara de cuero bollido o de hierro, una cervellera (en inglés llamado skull-cap) o un bacinete sencillo. En Tannenberg, en Pomerania (Alemania del Este), se ha encontrado - hace un siglo- un yelmo de tonel con su bacinete todavía por dentro, de antes de 1399. Existen en varios museos de Europa ejemplares de tipo cervellera, algunas de éstas de origen español (ejemplar en el Musée de l'Armée en París, procedente de la colección de Georges Pauilhac y de Estruch y Cumella en Barcelona). Este ejemplar, sin duda, tiene su origen en Calatayud o en Zaragoza. Otro ejemplar se encuentra en la Torre de Londres. La cervellera puede ser cubierta con un forro, por ejemplo, de pergamino, de seda o de otra clase de tela, pintada o bordada heráldicamente. La literatura de la época menciona con frecuencia estas cervelleras, con sus forros de seda, tela o cuero, y dice: «muy rico paño de seda o de cuero», «pintado con ornamentos o figuras heráldicas». Así era, según la poesía, el yelmo de El Cid, ya difunto, en su viaje hacia Burgos. Cervelleras hechas de cuero bollido han sido halladas en excavaciones en Palestina, de la época de las 


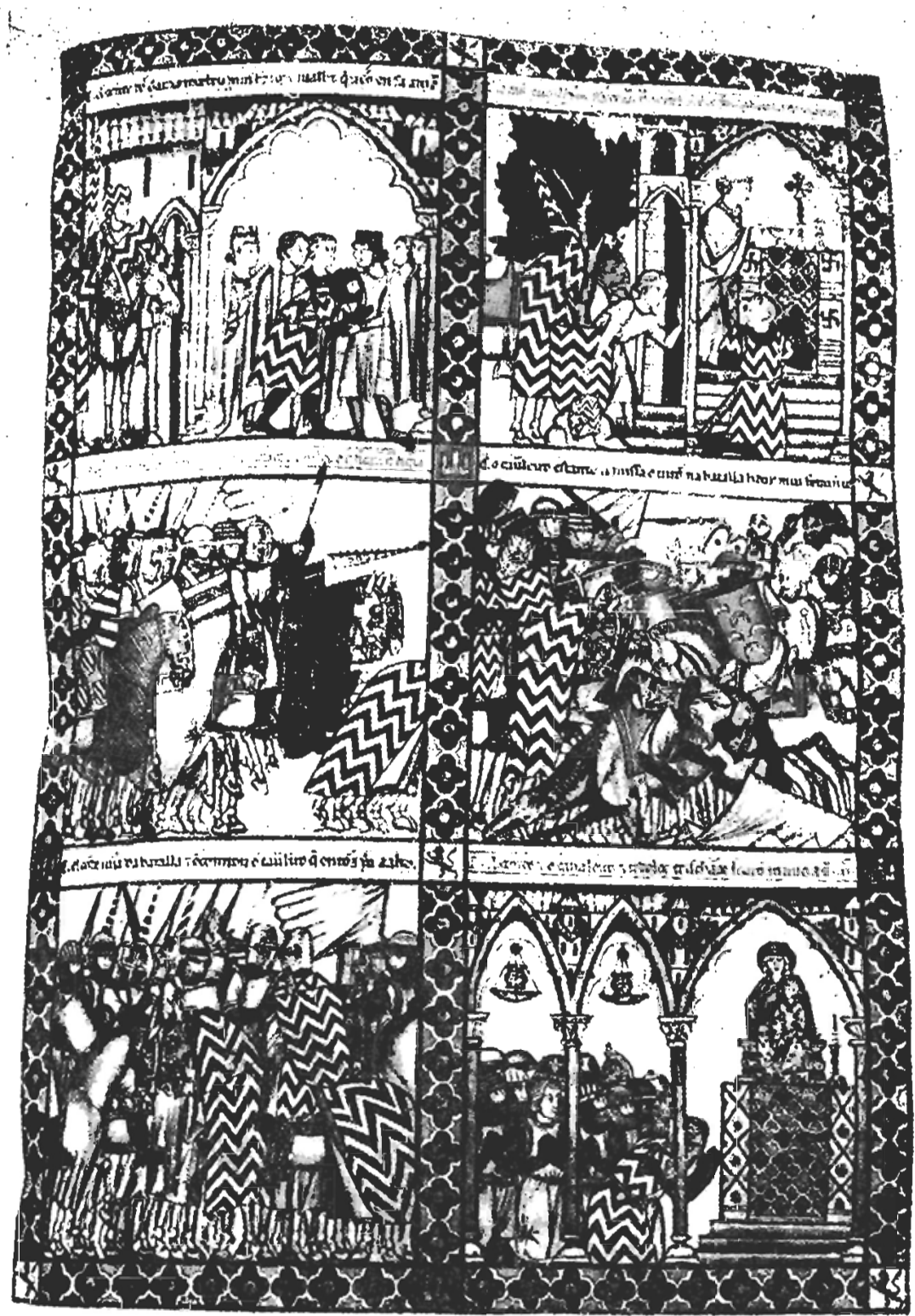

Fic: 28.-Cant. LXIII: El conde don Guría recibe bien a wn caballero que wiens a ayidarle comtra los moros. Buenas representaciones de armamento, especialmente de yelinos da tond, capellomas, coberturas y lesteras de caballos. Hérúldica cristiana $y$ mora. escudas de lipo U y uriargas. 
últimas Cruzadas, junto a restos de ballestas y hierros de saetas, todo procedente de asedios sarracenos, y también fuera de los castillos motos.

La protección más importante de esta época, al lado del yelmo de tonel, es, sin cluda alguna, el capiello de fierro (el capillo de hierro) y la capellina. Corresponden más o menos a los chapeaux-de-fer y chapeaux-

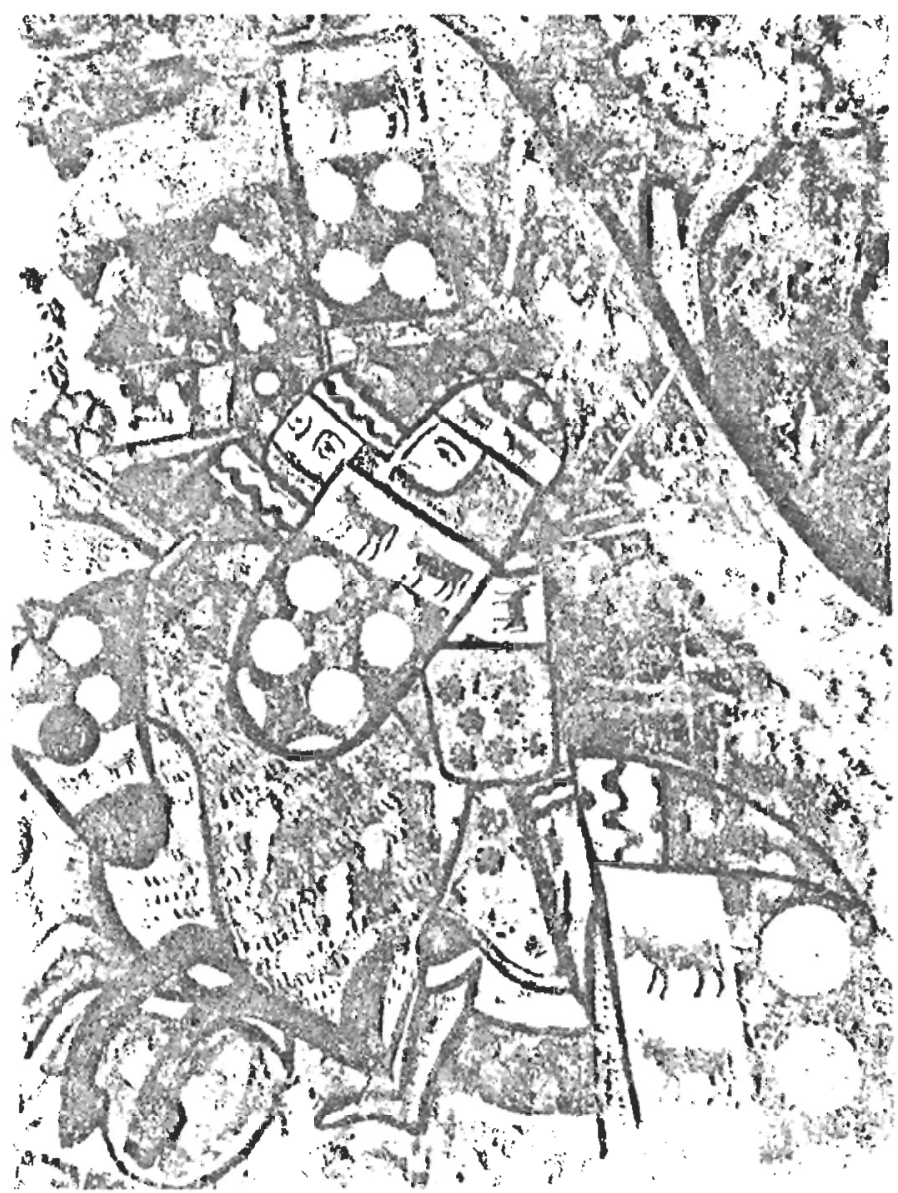

Fig. 29-Detalle de pintura mural de la Casa de Beronguer d'Aguilar, del Carrer de Monicada, en Barcelona, boy en el Museo de Arte de Barcelona. Bucn cjemplo de coto de malla, cervellera, loriga para caballo con lestera, probablentente de ctero bollido, escudo de lipo U, todo con beráldica: De Montcada i Bearn. Siglo XIII. 
de-Montaubain de Francia. El capiello de fierro o capillo de hierro es el yue lleva alas largas. La capellina es el capiello de fierio con alas pequeñas o casi sin alas. l'recuentemente, los moros tienen en sus capellinas la superficie cubierta de ornamentos. Ambos tipos - entre cristianos y moros-, en Las Cantigas, son adornados con figuras de tipo heráldico, con rayos rectos u ondulados, puntos y otros tipos de adorno. Probablemente se trata de una clase de forro de cuero, pergamino o tela, pintada o bordada (Fig. 29). La literatura de Castilla habla de bacinetes de cuero fuerte, aunque normalmente estas protecciones eran de hierro. Durante el siglo XIV y la primcra parte del xv estos bacinetes tienen una extensión enorme; el tipo más importante y favorecido de la época medieval baja? es el bacinete, con su visera o careta móvil y con su ápex alıo y frecuentemente puntiagudo.

\section{Los moros en «Las Canligas». Escudos moros y cristianos}

En Las Cantigas, Ios hispano-moros van vestidos aproximadamente igual que los cristianos; pero un grupo se distingue al ir vestido en estilo oricntal. Sus yelmos están adornados con grandes flores de lis y hojas de acanto encima de su ápex. El tallo del adorno sirve como nasal grande, como protección de la cara, aunque no son idénticos a los yelmos de ripo tonel. Otros grupos ticnen protección de cabeza en forma de pbrygiun cap o gorro de satrap de Persia. Estos gorros deben ser de cuero. El manuscrito de Scylitzes en Madrid lambién los menciona. Formas como cucurucho también se ven algunas veces, pero ya son anticuados. Muchos de los sarracenos tienen - cubriendo su cervellera de metal- un turbante. Hay varios tipos y formas de turbante, probablemente significando diferentes clases sociales y rangos militares. Estos turbantes están combinados con grandes capas o marlotas de brocado. Además, estos moros llevan sus propios escudos, las adargas de cuero de ante bollido (Fig. 30).

En el siglo xill se aprecia un cambio en el tipo de los escudos. En general, puede decirse cue los escudos de tipo almendrado y los grandes de tipo normando tienden a desaparecer. El desarrollo se puede seguir en los scllos reales y nobles, aunque con ciertas reservas; estos escudos, algunas veces, son para paradas y revistas de tropas y guerreros. Buenos ejemplos pueden verse en ilustraciones, retablos y pinturas murales, aunque no son frecuentes.

Los escudos cristianos de la época de Alfonso el Sabio y Jaime el Conyuistador pueden generalmente clasificarse en tres tipos principales: el triangular (isósceles), que es raro, pero algunas veces se notan en Las Cantigas y Gran Conquista de Ultramar, pero apenas en arte catalán. El escudo en forma de U, que en Las Cantigas es el más corriente y en 


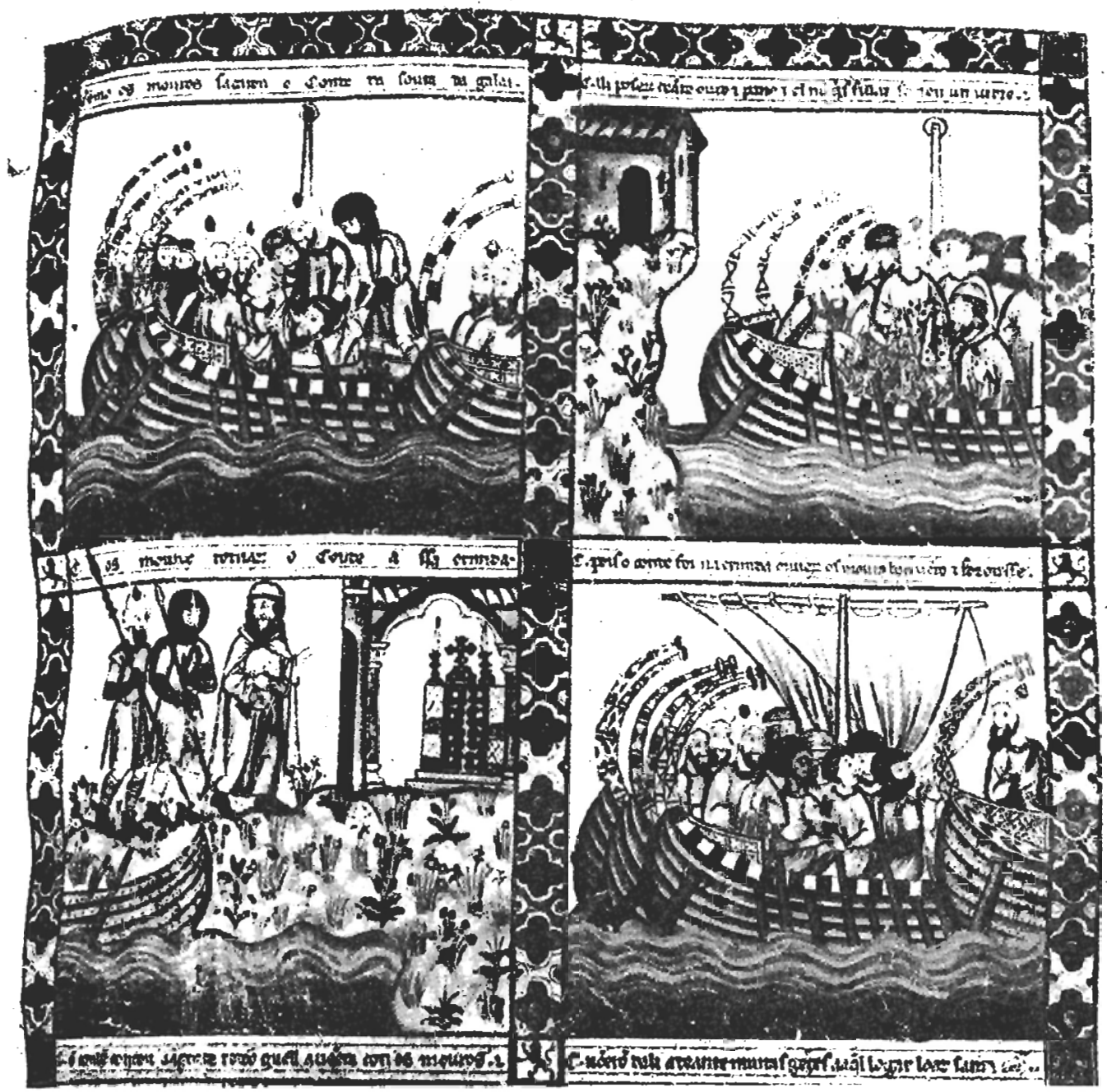

FIG. 30.-Cant. XCV. Vestimenta caracteristica mora, galera mora cerca de una ermita en Porlugal. 
Castilla el más característico; este tipo, en el extranjero, frecuentemente es conocido con el nombre de escudo español o escudo heráldico; se encuentra también en el arte catalán de la misma época. El escudo corriente en gran parte de Europa en esta época, y también conocido en España, pero con menos frecuencia, es la forma llamada beater-type (forma de plancha). En España es más usual en el siglo xiv. Aquí tiene muchas variaciones y tamaños, especialmente en los relieves laterales de las tumbas esculpidas. El material —según los ejemplares conservados en Alemania, Suiza y otros países europeos, y según las fuentes literarias de Españaes tabla de madera, forrada con cuero o pergamino fuerte con una capa de yeso. Sobre este último están pintados figuras heráldicas, los blasones del dueño, en oro, plata y colores heráldicos. Tienen sus brazales y tahalís de cuero, frecuentemente forrados con terciopelo. Alfonso el Sabio dice en una cédula de 1280 (dada en Sevilla): «Los escudos deben ser de tabla, forrados con cuero de los caballos, las bestias de mulas o asnales, y no con otro material ninguno.» Así son también los dos grandes escudos en la Real Armería (D 59 y D 60) (Fig. 8a-b).

De esta época es la costumbre funeral de llevar los escudos heráldicos de los nobles colgados, invertidos, al lado de las sillas de los caballos enlutados, detrás del féretro, entrando así en la iglesia, con caballo y todo el armamento, para la ceremonia del entierro. Terminadas las ceremonias funerarias, los escudos se colgaban en la pared de la capilla, encima de la tumba del difunto. Esta costumbre no sólo se conoce en España y en Portugal, sino que se ha usado también en otros países europeos. Al final del siglo xiu existe una heráldica bien desarrollada, que crece cada vez más durante los siglos xiv y Xv. Es bien conocido en el siglo xıv, donde gran parte de las tumbas esculpidas, con sus estatuas yacentes del noble difunto, con todo su armamento, tienen sus losas laterales cubiertas con este tipo de escudos heráldicos.

\section{El final de la Reconquista de Estaña FRENTE A AFRICA}

El siglo xin es la gran hora de la Reconquista. Comienza con la famosa batalla de las Navas de Tolosa, en 1212, con la vicioria de Alfonso VIII, y continúa con fuerza como una verdadera Cruzada contra los moros por San Fernando y sus hijos, aunque se estancó en los últimos años del siglo por causas internas. Es la época de los sueños imperiales de Alfonso el Sabio, lleno de ideas sobre el antiguo Imperio romano y su cultura y con el enorme desarrollo cultural en historia, arte, legislación, astronomía y filosofía. Las armas en la historia están excelentemente re- 
Gladius, Vol. especial (1988), pp. 31-101

presentadas en los manuscritos y las ilustraciones, inspirados y vigilados por el mismo Rey Sabio.

Se nota en Alfonso el Sabio el excelente conocimiento de los autores antiguos romanos, como el inmortal Vegetius y otros, como Aelian, etc.

Pero no fue él - por causas internas-quien puso fin a la Reconquista contra los moros de Africa, y tampoco sus propios hijos; fue el rey Alfonso XI el que, en la famosa batalla a las orillas del río Salado, cerca de Tarifa, venció a los benemerines en el año 1340. No sólo para la historia, también para las armas, esta batalla fue muy famosa. Además, con esta victoria, comicnza un cambio en el armamento y en cl arte de la guerra. Se inicia en la Península Ibérica el uso de la pólvora, ya usada por los moros en 1341 y por Alfonso XI en 1342. España entra en una época difícil, con guerras civiles y con influencia del exterior en cuanto a armamento y arte de la guerra, introducido por el Príncipe Negro, Eduardo de Inglaterra, y las Compañías Blancas del condottiere francés Bertrand Duguesclin.

La primera parte del siglo XIV significa, sin embargo, una continuación tranquila del siglo de la Reconquista. Pero antes de llegar a la mitad del siglo se aprecia un cambio en el armamento, en el arte de combatir y en la selección de los temas de guerra y armas en todas las representaciones del arte. Hay ahora menos manifestaciones de batallas, menos encuentros con armas. Las representaciones buscan sus temas, cada vez más, en el Nuevo Tesıamenio: la Pasión, el Calvario, el Santo Sepulcro, la Resurrección; también en ejecuciones de mártires, aunque — naturalmentetambién se muestran otros temas. En las diferentes regiones de la Península se aprecian variaciones. Castilla se distingue de Cataluña-AragónValencia. Andalucía es diferente a las Mesetas y a Cataluña. Navarra está relacionada con el sur de Francia y probablemente con Borgoña.

Todavía hay escasez de material arqueológico. Pero ahora domina un material de gran importancia: las lumbas esculpidas, con sus realistas estatuas yacentes encima de sus tumbas, algunas vestidas solamente con loriga completa; otras también con perpuntes o cuirasses sobrepuestas sobre la loriga; otras, en fin, con sus armaduras «blandas». Es muy corriente el arnés completo de metal rígido, para piernas y brazos. Los sabatones son de láminas flexibles de hierro o de escamas de metal o de ballena. Los caballeros llevan sus bacinetes abiertos y adornados, sus guantes de hierro articulado, cinturones militares, rica y bellamente ornados. Las espadas son grandes tajadoras, frecuentemente con su suspensión de correas de cuero muy bien aclornado; las vainas bordadas con seda, hilo de oro y plata. Es frecuente que también pueda verse una elegante daga al lado derecho del difunto, conjuntada con su espada (Fig. 31). De cuando en cuando aparece también un escudo grande y adornado con el blasón 
Gladius, Vol. especial (1988), pp. 31-101 Actas del I Simposio Nacional

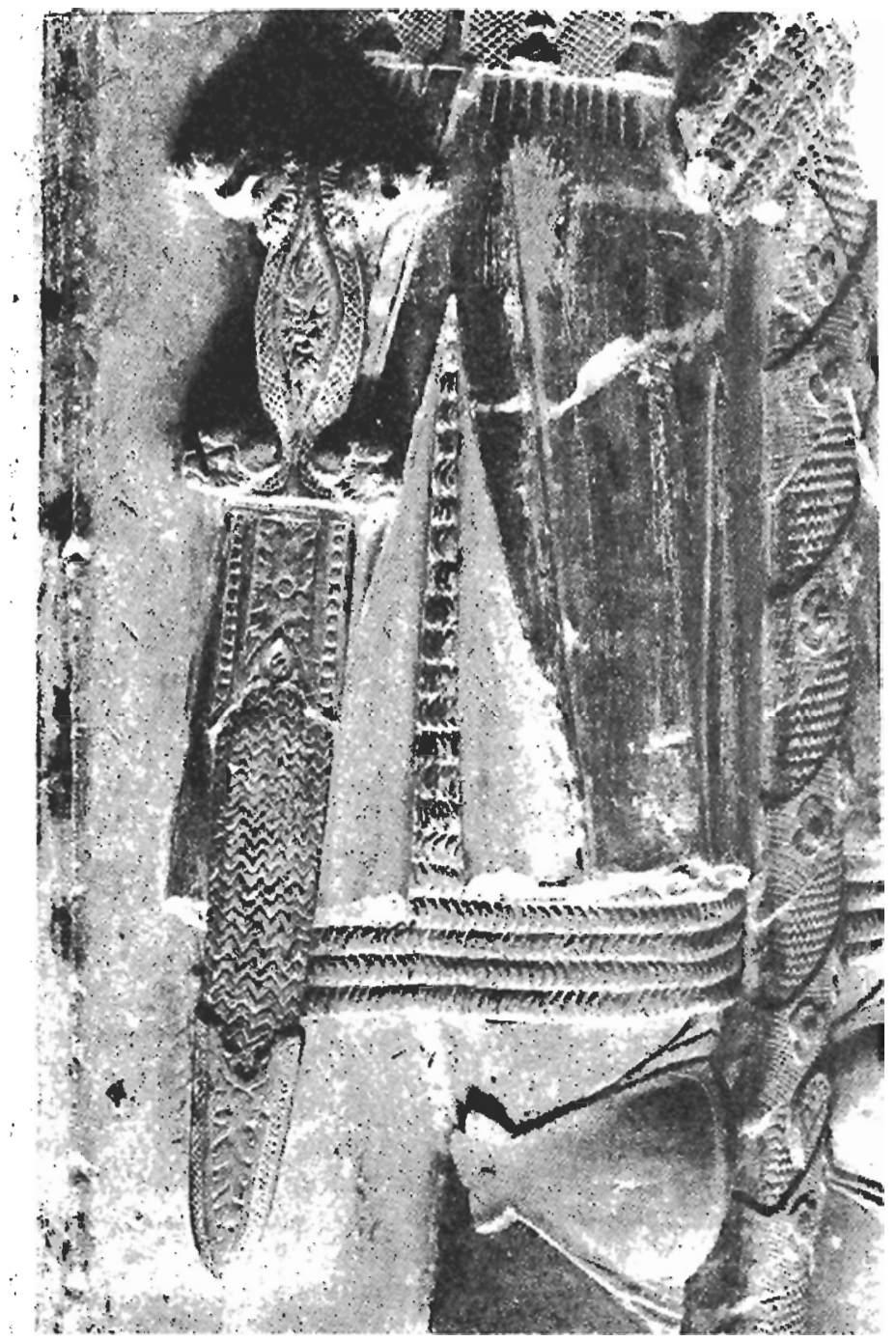

Fug. 31.-Efigie del monumento de Hug. de Copons, wh. 1354. Delalle con daga preciosa en sa vaina y parle de la vaina de sa espada. Se nola su loriga de malla y arnés de piernas de micial rigido. Mus. Arqueol. Diocesamo, Solsona. 
del caballero. Los relieves en los laterales de la tumba muestran los escudos de la familia, con sus figuras y símbolos heráldicos, o representan escenas de la Pasión, especialmente la guardia de los soldados romanos, dormidos, vestidos con armamento completo en todos los detalles y con las armas: espadas, hachas, lanzas, guisarmes, etc., a sus lados (Fig. 32). Tienen gran importancia, respecto al armamento, porque con frecuencia suelen ser muy detallados. En las pinturas murales y los retablos, u orros tipos de tablas pintadas, la Resurrección misma es tema dominante, donde se ve a los soldados con su armamento al pie del Santo Sepulcro.

Existe en el arte un buen surtido de brigantinas (Fig. 34), cuirasses superpuestos a los lorigones de malla, con sus cuellos reforzados y con

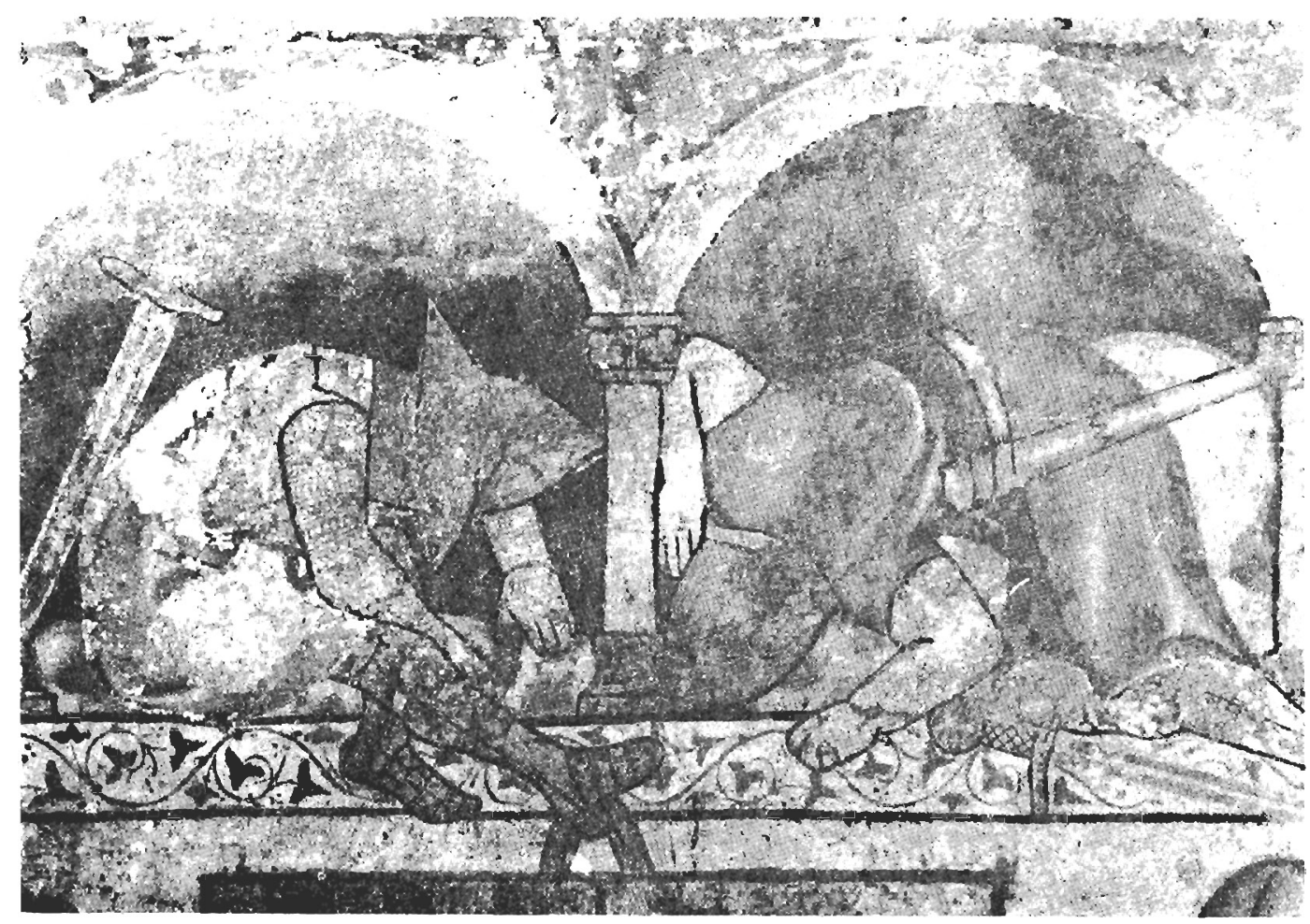

FIG. 32.- Sanlo Scpulcro, soldados romanos desmayalos, con capillo de bierro, bacinete, arnés de piernas de metal rígido, sabalones articulados y espadas lipo español. Refectorio. Catedral de Pamplona. 
Gladius, Vol. especial (1988), pp. 31-101 Actas del I Simposio Nacional

petos de acero forrados con terciopelo, cuero, tela, etc., fijado con clavos grandes, dorados y decorativos. En algunos tipos de cuirasses, casi estilo «poncho", y parecidos a otros de los hallados en las grandes excavaciones del campo de batalla fuera de Visby, Gotlandia, en Suecia, en 1361, se ven, por ejemplo, escenas de la Pasión en el altar de Bernat Saulet (Cataluña) de 1341 (Fig. 33). Aquí se nota también el prototipo del capacete español, famoso en toda Europa a finales del siglo xv y comienzos del xvi.

Generalmente, las armas suelen ser lanzas, martillos de guerra con mangos largos usados por la caballería y cortos para la infantería, también hachas largas para caballería y cortas para infantería (Fig. 36).

Los tipos que se conocen en España también pueden encontrarse en otros países europeos. Tumbas esculpidas y realistas, de alta calidad, existen en Alemania, con soldados romanos completamente armados; otros son de Austria, Baviera, etc. De estilo diferente son los famosos monumentos de Inglaterra: placas grandes de bronce con los difuntos labradas con todo detalle en metal, con importantes representaciones del armamento inglés de ese siglo. Igualmente son de gran importancia unos pocos manuscritos ilustrados del siglo xiv, ya que en ellos se nos muestran escenas de batallas, grupos de caballeros con todo su armamento, luchando con ferocidad con otros grupos de caballeros. Entre ellos hay que mencionar, por ejemplo, el manuscrito «Roman del Rey Meliados», de aproximadamente 1360 (Brit. Mus. AD. Add. M. S. 12, 228). De hacia 1330 es el «Chronique de Saint Denis», sobre los reyes de Francia; «Histoire Universelle», de 1330; «Roman de Aleixandre»; más el manuscrito flamenco del mismo nombre (ca. 1338-44), así como otros varios. Comienzan en este siglo las ilustraciones que representan escenas de caza, con sus armas caractcrísticas para este recreo y deporte de las Cortes españolas y europeas.

Los documentos extranjeros no sólo informan sus respectivos países, sino que también lo hacen para España, dado que la Península Ibérica recibe ahora su influencia, especialmente de Francia e Inglaterra, y ello a causa del comienzo de la Guerra de los Cien Años entre Francia e Inglaterra, por los mercenarios franceses, italianos e ingleses que penetran en la Península con Bertrand Duguesclin y sus Compañías Blancas, así como con el Príncipe Negro de Inglaterra. Además, las informaciones españolas se confirman por fuentes extranjeras, por ejemplo, las crónicas de Duguesclin, Froissart, Sire de Joinville y otros historiadores y cronistas del siglo.

Las fuentes literarias españolas de la época son ricas y ofrecen buena información. Las fuentes son, como antes, crónicas de Pedro López de Ayala, de finales del siglo xiv, fueros, testamentos e inventarios; pero ahora comienzan también los ordenamientos de los gremios. Hay que añadir las obras de poesía y alegóricas, como la muy importante de Pere 


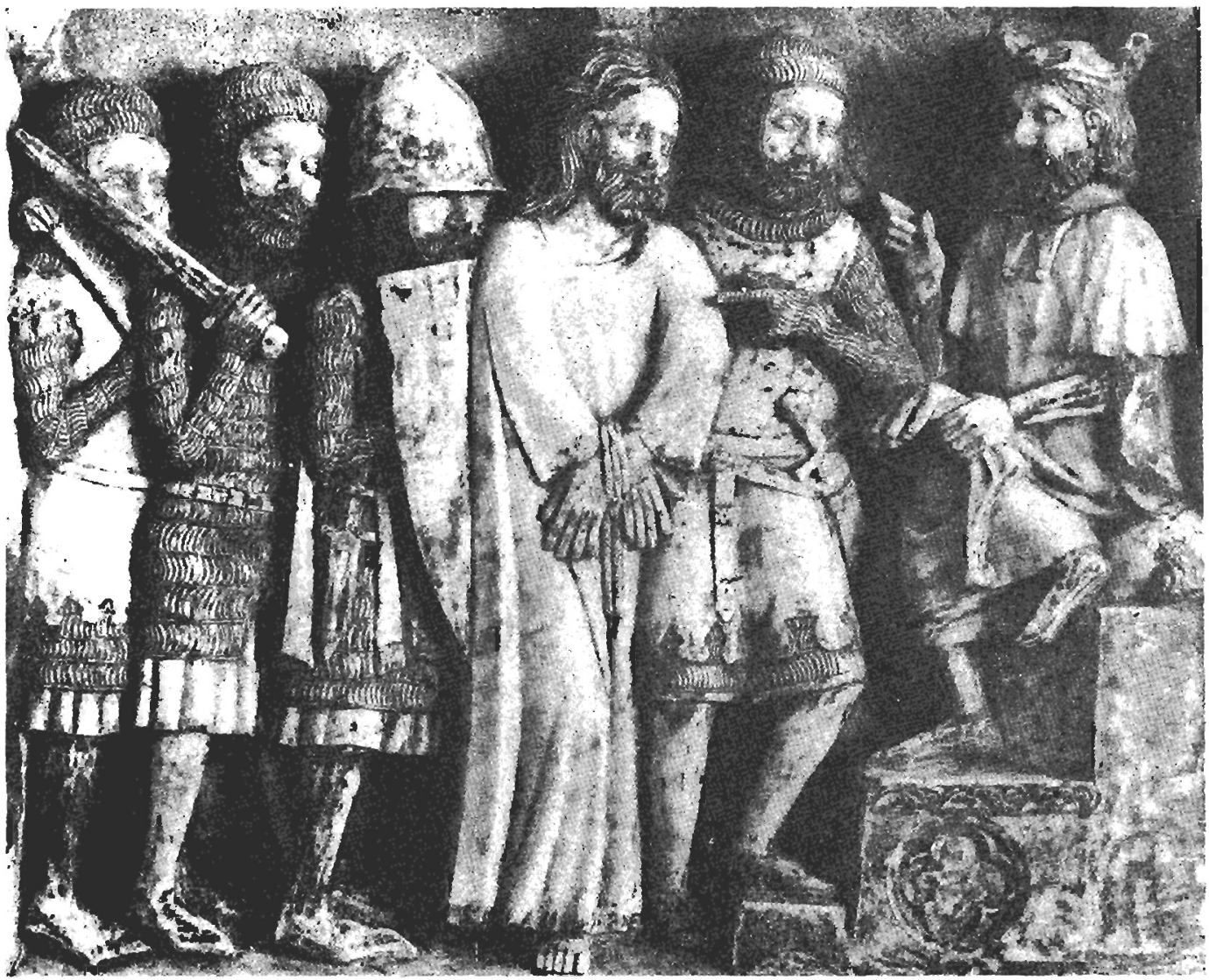

Fig. 33.-- «Cuirasses» de cuero, por dentro con placas de bierro. Del retablo de la Pasión de Bernat Saulel, ca. 1341, de Sant Joan de les Abadesses. Hoy en el Musco Episcopal de Vic. Tipo parecido a los encontrados en el campo de balalla cerca de Visby, Gotlandia, Succia, de 1361.

March, con su Arnès del Cavaller, de Cataluña (tratado fundamentalmente por Martín de Riquer), o del monje franciscano Francesc de Eiximenis, con su Dotzé del Chrestia, de Valencia. Se puede añadir a las ya dichas de Cataluña y Castilla, etc.

De Andalucia - de Granada, con su Alhambra-, existen dos fuentes de gran importancia: como las pinturas de cuero esculpido, pintado y do- 


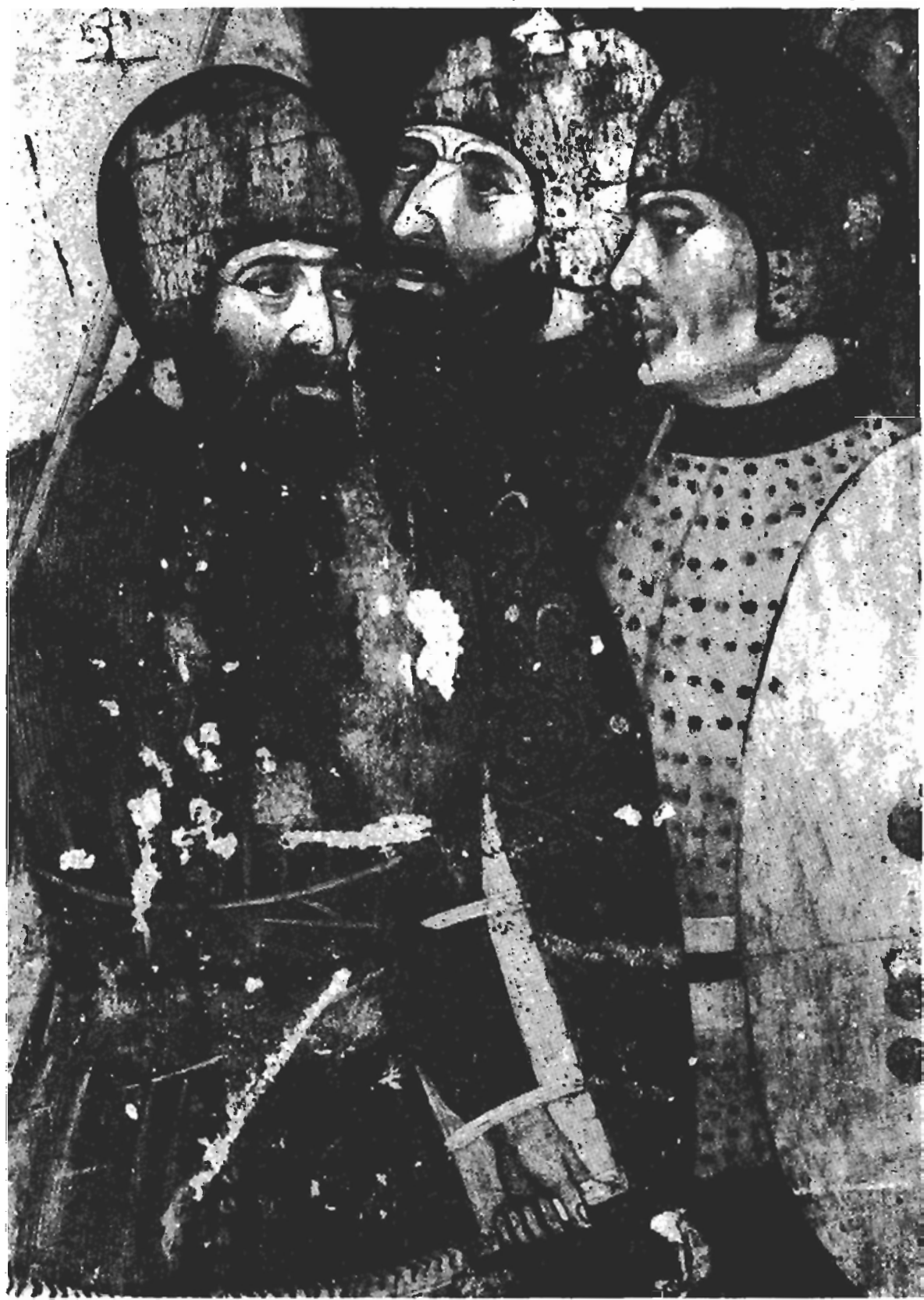

Fic. 34.-Escena del Calvario de los bermanos Serra, ca. 1350, Museo Episcopal de Vic: Tipos de brigantinas con sus clavos dorados, cuellos de malla doble y bacinetes redonderdos. Los escudos ozdados son del lipo característico para escendis biblicas de la ćpoco. 


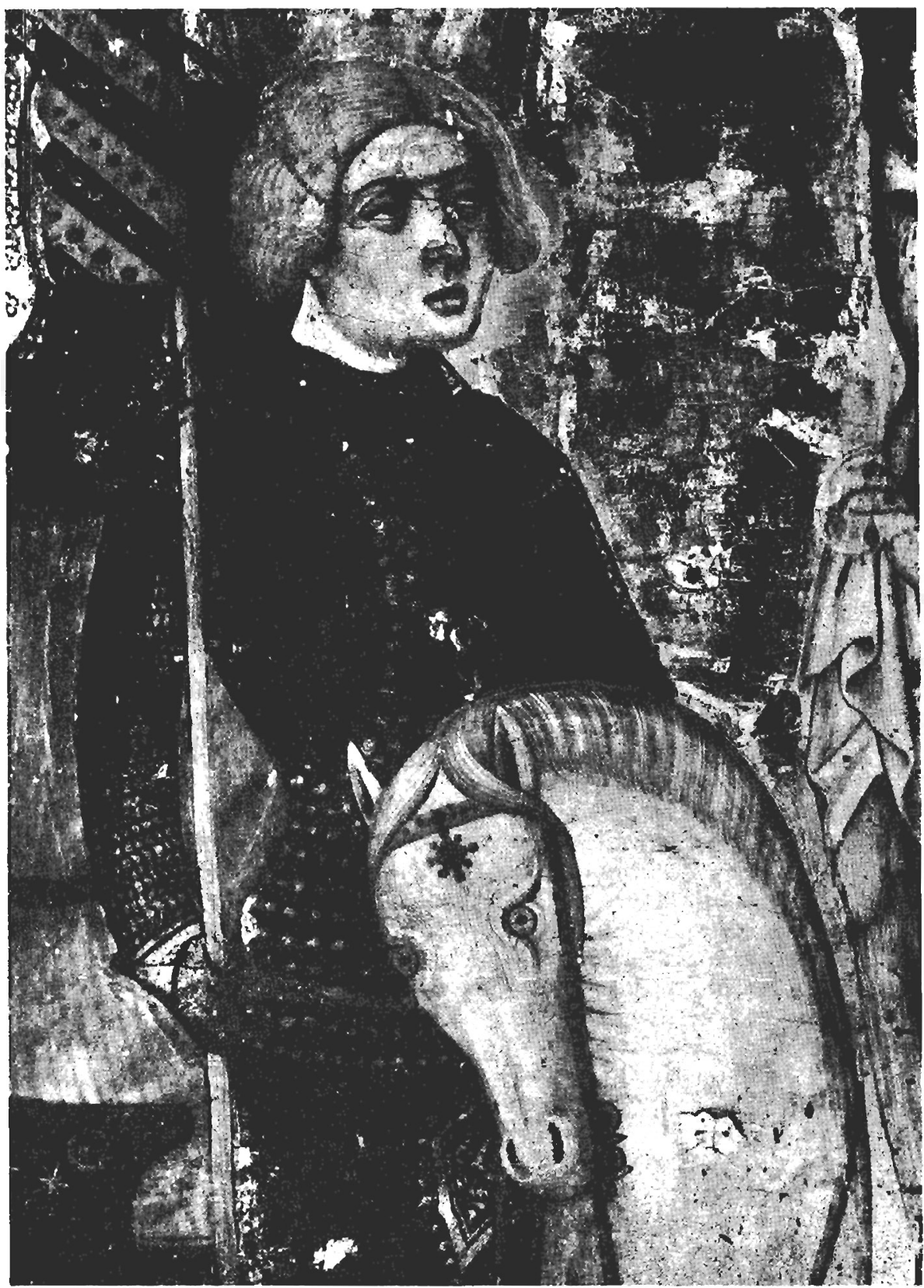

FIG. 35.-Jacaut de melal rigido lorrado con leviopelo carmesí, con clavos probable. mente de bronce dorddo; abajo, láminas de metal con terciopelo carmesí con davos. Todes encima de una camisa o lorigón de malla. Con éste estamos en los umbrales de la «amadura blanca». Detalle del mismo Calvario de los bermanos Serra, ca. 1350 , 
rado una de ella, en el techo de la Sala de Justicia; otras murales en la Torre de las Damas, en el Partal. Esta última, con sus frisos, nos muestra un armamento más oriental que el de Las Cantigas, que se corresponde bien con las descripciones del historiador Ibn Hayan. Ibn Hudail, en su libro, nos ofrece unas descripciones interesantísimas respecto al armamento de su tiempo utilizado por los moros de Alhambra, del siglo xiv. Trata en su libro sobre toda clase de armas: ofensivas, defensivas, deportivas, para la hípica, etc., todo desde el punto de vista del profeta Mahoma. Pero probablemente hay que utilizar este libro con cierta reserva. Respecto a los musulmanes antiguos en Andalucía, puede darse referencia de un libro de gran importancia sobre armas en la poesía árabe antigua, con descripciones de las armas, no muy distintas de las de la poesía trovadoresca del sur de Francia, Provenza y Cataluña, aunque con estilo, tipo y manera de composición diferente a las de las fuentes occidentales; F. W. Schwarzlose, en el siglo pasado, en su libro Die Waffen der alten Araber aus ibren Dicbterin dargestellt, nos of rece una obra muy útil e instructiva para investigadores. Podemos también referirnos a la importante obra de Reinhardt Dozy, el Holandés, que en el siglo pasado escribió su larga historia sobre los musulmanes en España, editado en cuatro tomos (tratando las invasiones árabes y los califatos).

La época más importante en el siglo XIV es la de aproximadamente 1330-50, especialmente después de la batalla de Crȩ̧y, en 1346, donde nos encontramos con el primer, grande y decisivo fracaso de la caballería francesa, pesadamente armada, tanto el hombre como el caballo, frente a la nueva táctica inglesa de sorpresa: los caballeros desmontados y de a pie, con lanzas acorladas, y más importante todavía: los grandes arcos de los ingleses, arcos de Gales. La despreciada infantería - los «obreros» de la guerra, con sus armas especiales: picas, alabardas, mordaxten, etc.comienza a abrir huecos entre la orgullosa caballería de la nobleza y de los señores feudales, con sus lanzas en ristre, largas y pesadas, y sus tremendos choques con la lanza, una táctica que poco a poco conduce a la ruina de la caballería, para terminar con el definitivo fracaso en la batalla de Nancy, en 1477, donde el «último Caballero», Carlos el Temerario, de Borgoña, con su armamento de acero para hombre y caballo, fue mortalmente herido por una alabarda de un infante suizo.

Paralelos con las guerras en Francia - la Guerra de los Cien Añosiban los fracasos en Europa central, entre otras Suiza, con su lucha para la liberación del país de la dominación austríaca: Moorgarten en 1315, con mordaxten; Laupen en 1339, con alabardas y picas, y Sempach en 1386, con espadas de tipo «estoque», las Ilamadas espadas de Sempach (según esta batalla). Estas batallas hacen que cambien los tipos de armas de guerra. La caballería feudal, con sus lanzas de choque, todavía no que- 
Gladius, Vol. especial (1988), pp. 31-101 Actas del I Simposio Nacional

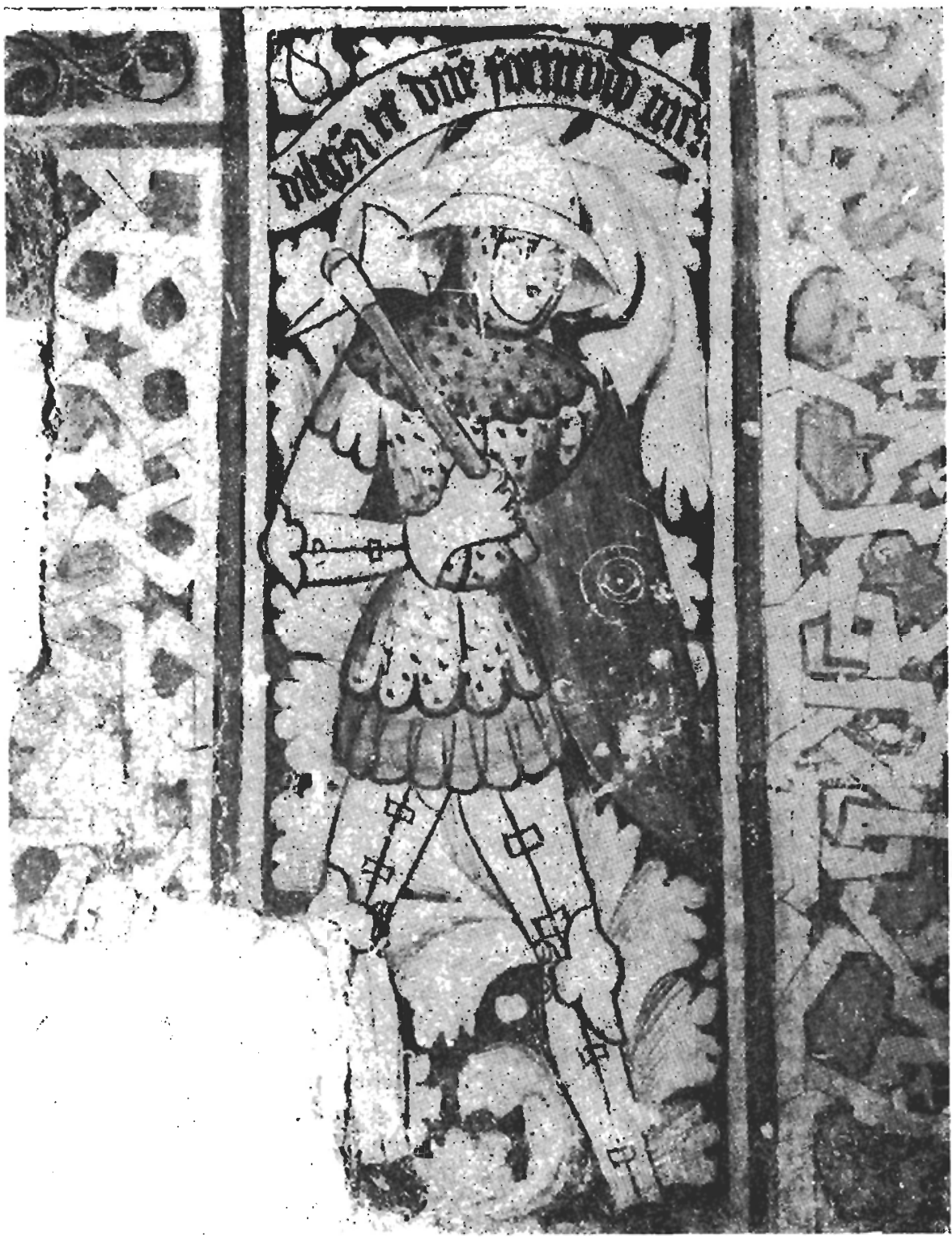

Frg. 36.--Infante castellano con capillo de hierro estilo de Monlaubain, capucba y jacque del e'slilo nuevo de! siglo XIV, prolección de melal rigido para brazos y piernas. Hacha para la infanteria del rey Pedro al Cruet. Pintura mural. Museo Arquenlógico, Córdoba 
ría reconocerlo a pesar de sus duras lecciones y fracasos. Se armaron cada vez más fuerte y pesadamente en sus «estuches» de acero para caballero y caballo. Las novedades en el nuevo arte de la guerra y en su armamento, introducidas en la Península por Duguesclin y el Príncipe Negro con mercenarios internacionales y tropas de Inglaterra, fueron usadas con efecto en las batallas de Nájera en 1367, en Montiel en 1369, en Aljubarrota en 1385 y en Villalobos en 1386.

\section{CONCLUSIÓN}

Un vistazo retrospectivo sobre las armas en la historia y en el arte de la guerra durante la época medieval nos hace comprender que las armas y la forma de usarlas en la guerra, más la organización y sistematización militar, tienen una influencia importantísima para la historia política y cultural en el desarrollo de la sociedad y la vida social. Esto es especialmente evidente para la parte central, la cumbre de la época feudal, en dos sentidos: el militar y el social.

La Edad Media es la bisloria de la caballería pesada, con el casi todopoderoso rey como principal figura en el centro, rodeado por su séquito de vasallos de la nobleza como única fuerza activa en la guerra, sea en su primer desarrollo, en su cénit (las últimas Cruzadas) o en su decadencia. Un desarrollo que en realidad había durado más de mil años y tuvo su origen y sus primeros éxitos —aunque, probablemente, por casualidaden la batalla de Adrianópolis, en el año 378 con los godos, sus caballos, sus fuertes espadas y largas lanzas contra los ejércitos imperiales de infantería de los romanos para terminar en la famosa de Nancy, en 1477, con el fracaso y muerte de Carlos el Temerario de Borgoña.

Entre estos dos puntos - solamente con unas interrupciones durante unos pocos siglos, la época de los merovingios en Francia-, las armas y la táctica de la caballería feudal, desde sus nacientes comienzos bajo el emperador Carolus Magnus hasta el siglo xiv, dominaban los campos de batalla de casi toda Europa. En el sur de la Península se combinó con la caballería ligera de jinetes hispano-moros y berberiscos. Las primeras indicaciones - todavía aisladas - de una futura catástrofe se notaron ya en la batalla de Courtrai, en 1302, y en Pons-en-Pévèle, en 1304, más algunas otras en Inglaterra e Irlanda, continuando con las batallas en Suiza: Moorgarten, Laupen y Sempach. Más significativa todavía fue la batalla de Creçy, en 1346, una de las más importantes en la Guerra de los Cien Años. En España, las batallas más significativas fueron las de Nájera, Montiel, Aljubarrota y Villalobos.

Otra clase social (guerreros de a pie), otros tipos de armas: lanzas 
acortadas, arcos largos y rápidos de los ingleses, varios tipos de armas de asta y, entre ellos, en la Península, las hachas, comenzaron a tener importancia decisiva en los campos de batalla. Las armas y la nueva táctica de movilidad de la infantería decidieron el resultado de la batalla y, de este modo, también el curso de la historia política. Cada fracaso inspiraba a los caballeros una protección más fuerte y más pesada, pero con menos movilidad tanto para el hombre como para el caballo. La época de la caballería terminó definitivamente en el campo de Nancy.

La época medieval tuvo mucho color, con buenas y hermosas armas ofensivas y defensivas, de acuerdo con el valor, gusto y economía del caballero. La guerra fue una serie de choques multicolores entre relativamente pequeños grupos de caballería, casi una clase de torneo, brutos, duros y hasta desordenados, con una táctica y una estrategia que se estancó. Los progresos de alguna importancia en el arte de la guerra fueron muy pocos durante siglos. Una de las causas de estos fenómenos probablemente tenga sus raíces, entre otras cosas, en las condiciones sociales, la economía de los reyes y caballeros feudales, los enormes gastos para crear, comprar armas y mantener ejércitos de caballería, así como pagar mercenarios, los verdaderos «obreros» de los ejércitos. La caballería de la nobleza perteneció a la propia clase militar durante toda la época medieval, el símbolo de la guerra medieval, donde el valor personal del rey, con su séquito de vasallos de la nobleza, tuvo estima e importancia, rodeados de cierta aureola por la historia y el arte y glorificados por la literatura épica en las chansons de geste, crónicas y poemas alegóricos.

\section{BIBLIOGRAFIA SELECTA}

Agundo Bleye, Pedro: Mannal de Historia de España, I-III, espec. tomo I (Madrid 1958).

Ainnud de Lasnkte, J.: Pintures del Segle XIII al Carrer de Montcada de Barcelona, Real Academia de Buenas Letras (Barcelona 1969).

Alfonso el Sabio: Las Siete Partidas, ed. de la Real Academia de la Historia, 3 vols. (Madrid 1807).

Alronso el Sabio: Las Siete Partidas, glosadas por el Lic. Gregorio López, 4 vols. (Madrid 1843).

Alfonso el Sabio: Primera Crónica General. Estoria de España que mando componer Alfonso el Sabio y se continuaba bajo Sancbo IV en 1289. Publ. por Ramón Menéndez Pidal, tomo I. Texto Nueva Biblioteca de Autores Españoles, tomo V (Madrid 1906).

Arriba Palau, Antonio: La conquisla de Cerdeña por Jaime II de Aragón (Barcelona 1952).

Busir, Claude: Medieval Swords and Spurs in Toledo Catbedral, en «Journal of the Arms and Armour Society», vol. VIII (Londres 1952) págs. 41-52.

Blatr, Claude: European Armour ca. 1066 lo ca. 1700 (Londres 1958). 
Blatr, Claude: European and American Arms, ca. 1100-1850 (Londres 1962).

Bruhn Hoffimeyer, Ada: Middelalderens Tveaeggede Svaerd, I-II (sumario en inglés) (Copenhague 1954) (Tesis doctoral).

Brunin Hoffmeyer, Ada: Antikens Artilleri, Frem til tidlig Middelalder (Greek and Rornan Artillery up to Early Middle Ages) (rexto en danés) (Copenhague 1958).

Bruin Hofrmeyer, Ada: From Medieval Sword to Renaissance Rapier, en "Gladius», II (Madrid 1963).

Bruhn Hoffmeyer, Ada: From Medieval Sevord to Renaissance Rapier, edición aumentada, en Robert Held: Arms and Armour. An linternational Antbology (Chiasso, Suiza, 1979-80).

Bruhn Hoffueyer, Ada: Arms and Armour in Spain. A Short Survey, I (Madrid 1971) y II (Madrid 1982).

Bunns, Robert (SJ): Moors and Cruzaders in Medilerranean Spain (Collected Sudies) (Londres 1978).

ButTin, François: La Lance et l'Arrêt de Cuirasse, en «Archaeologia», vol. XCIX (Oxford 1965).

Buttin, François: Du Coulumo Militaire au Moyen Age et Pendant la Renaissance, en «Memorias de la Real Academia de Buenas Letras de Barcclona» (1972).

Calvert, Albert: Spanish Arms and Armour (Londres-Nueva York 1907).

Cirlot, Victoria: La evolución de la espada en la sociedad calalana de los siglos XI$X I I I$, en "Gladius», XIV (Madrid 1978).

Cirlot, Victoria: El armamento catalan de los siglos XI-XIV, I-ll (Tesis doctoral, inéd.) (Barcelona 1980).

Domíncuez Bordona, J.: La miniatura española, I-II (Barcelona 1930)

FerRandis, José: Espadas granadinas de la Jincta, en "Archivo Español de Arte», XVI (Madrid 1943).

Gómez Moreno, Manuel: Pinluras de moros en la Alhambra (Granada 1916).

Gómez Moreno, Manuel: Fl Panteón Real de las Huelgas de Burgos. Instituto de Diego Velázquez, CSIC (Madrid 1946).

Guerrero Lovillo, José: Las Cantigas. Estudio arqueológico de sus minialuras. Inslituto Diego Velázquez, CSIC, Sección de Sevilla (Madrid 1949).

Lnking, G. F.: A Record of European Armours and Arms through Seven Centuries, 1-V (Londres 1920-1922).

Leguinn, Enrique de (Barón de la Vega de Hoz): Espadas Históricas (Madrid 1898).

Leguina, Enrique de (Barón de la Vega de Hoz): Glosario de voces de armería (Madrid 1912).

Leguin, Enrique de (Barón de la Vega de Hoz): La espada española (Madrid 1914).

Llul.t, Ramón: Libre de l'Ordre de cavalleria, ed. de M. OBRador I BenNassar: ()hras de Ramón Llull (Palma de Mallorca 1906) págs. 232-236.

Lor, Ferdinand: L'arl militaire et les armées all Moyen Äge en Europe el dans le Prôche-Orient, I-II (París 1946).

Mann, Sir James $G$.: Notes on the Armour worn in Spain from the Tenth to the Fiflecuth Century, en "Archaeologia», LXXXIII (Londies 1933).

March, Pere: L'Arnes del Cavaller, ed. de Lluis Firaudo de Saint Germain: Recull de Textes Catalans Anticbs, aplec. III, vol. XV (Barcelona 1910).

Mendoza Eguarís. Angela, y otros: Ballesta nuzari del Museo Arqueológico de Granada, en "Cuadernos de la $A$ lhambra», 18 (Granada, 1982).

Menéndez PIDnL, Ramón: Historia de España, vols. VI, XIV-XVII. Espasa Calpe (Madrid).

Mentré, Mileille: La Peinture Mozarabe. PUPS, Casa de Velázquez (París 1984).

Monreal y TEjada, Luis: Ingeniería militar en "Las Crónicas». Real Academia de Buenas Letras (Barcelona 1971). 
Nicolle, David: Early Modiuval Islamic Arms and Armonr, en «Gladius», espec. (resumen en español) (Madrid 1976).

OnKESHOT'T, R. Evart: The Archaeology of Weapons (Londres 1963).

OAkEshot'r, R. Ewart: The Sword in the Age of Chivalry (Londres ${ }^{2} 1981$ ).

Oman, Sir Charles: History of the Arl of War in the Middle Ages, I-II (reprod.) (Londres 1970).

Osma, Conde de Valencia de Don Juan: Calálogo histórico-descriptivo de la Armería Real de Madrid (Madrid 1898).

Paiacios Martín, Bonifacio: lnveslidura de armas de los reyes españoles ell los siglos XII y XIII. "Primer Simposio sobre las armas en la historia» (Madrid-Cáceres 1986).

PAynf-Gallwey, Sir Ralph; The Crosshow, reedición (Londres 1958).

Pijońn, José: Summo Artis, vols. XI y XXII (Madrid 1947 y ss.).

Quasigroch, Günther: Der Topthelm von Dargen, en «Zeitschr. f. Historische W'affen- und Kostumkundes (Berlin-Munich 1979).

Relanzón Garcín-Criado, José María: La corona y la espada de Sancho IV de Caslilla, en «Toletum», Real Academia de Bellas Artes y Ciencias Históricas (Toledo $1959)$.

Riquer, Martín de: L'Arnis dol Cavaller. Armes i Armadures Calalanes Medicvals (Barcelona 1968).

Sńnchez-Albornoz, Claudio: La España musulmaua, I-II (Madrid 1956).

Soler del Cakipo, Alvaro: Fisludio comparativo de espuclas bajomedicuales, en "Arqueología Medieval Española» (Madrid, 1987).

Totedo: Alfonso el Sabio, ed. del Ministerio de Cultura, Dirección General de Be. llas Artes y Archivos, Museo de la Santa Cruz (Toledo 1984).

Vigón, Jorge: El Ejército de los Reyes Calólicos. Edirora Nacional (Madrid 1968). Viguera, María Jesús: Ibn Hudayl: gala de caballcros, blasón de paladines (Madrid 1977)

Zaky, A. Rahman: Gmmpowder and Arab Firearms in Middle Ages, en "Gladius». VI (Madrid 1967). 